\title{
Solomon Islands: Selected Issues and Statistical Appendix
}

The Selected Issues paper and Statistical Appendix for the Solomon Islands was prepared by a staff team of the International Monetary Fund as background documentation for the periodic consultation with the member country. It is based on the information available at the time it was completed on July 1, 2004. The views expressed in this document are those of the staff team and do not necessarily reflect the views of the government of the Solomon Islands or the Executive Board of the IMF.

The policy of publication of staff reports and other documents by the IMF allows for the deletion of market-sensitive information.

To assist the IMF in evaluating the publication policy, reader comments are invited and may be sent by e-mail to publicationpolicy@imf.org.

Copies of this report are available to the public from

International Monetary Fund • Publication Services

$70019^{\text {th }}$ Street, N.W. • Washington, D.C. 20431

Telephone: (202) 623-7430 • Telefax: (202) 623-7201

E-mail: publications@imf.org •Internet: http://www.imf.org

Price: $\$ 15.00$ a copy

\section{International Monetary Fund \\ Washington, D.C.}





\section{INTERNATIONAL MONETARY FUND}

\section{SOLOMON ISLANDS}

\section{Selected Issues and Statistical Appendix}

Prepared by Philippe Marciniak and Engin Dalgic (both APD)

Approved by the Asia and Pacific Department

July 1,2004

Contents

Page

Selected Issues

I. Prospects for Increasing Growth and Reducing Poverty .........................................

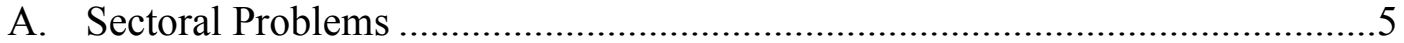

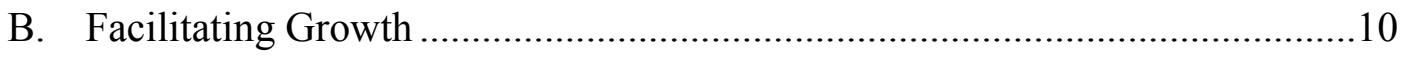

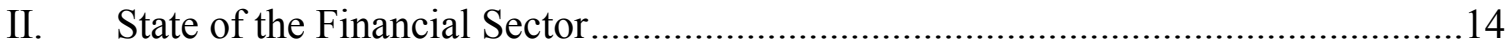

A. Financial System Assessment .......................................................................14

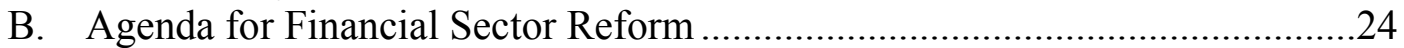

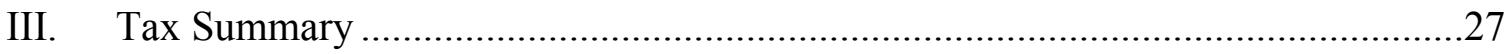

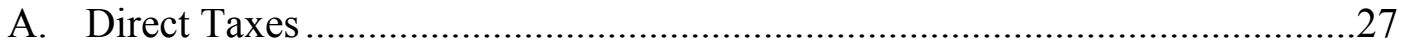

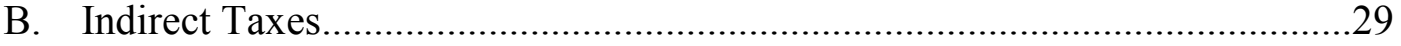

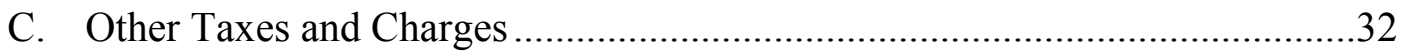

Boxes

I.1. Civil Conflict and the Multilateral Intervention..................................................

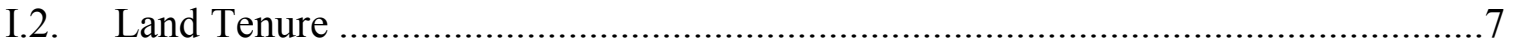

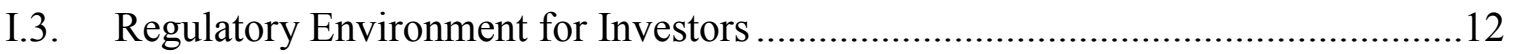

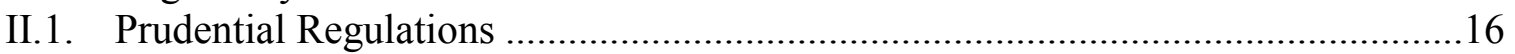

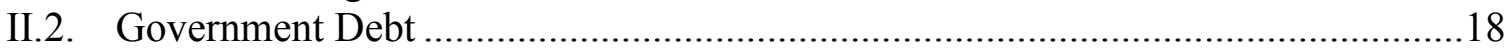

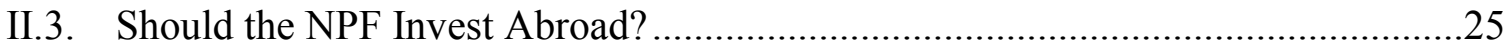

Figure

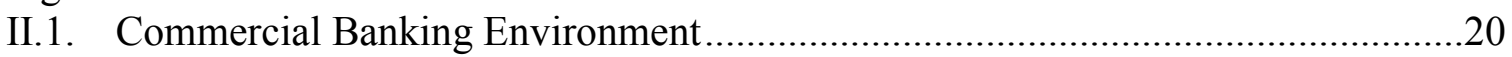

Tables

II.1. Financial Soundness Indicators of Commercial Banks, 1998-2003 ……...............19

II.2. Financial Soundness Indicators of the NPF and the DBSI, 1998-2003 ….............22 
Statistical Appendix

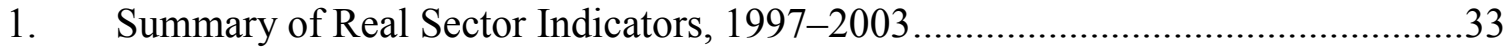

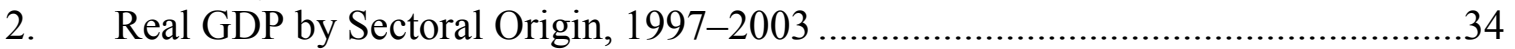

3. Real GDP Growth Rates by Sectoral Origin, 1997-2003 ....................................35

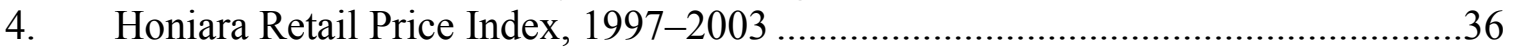

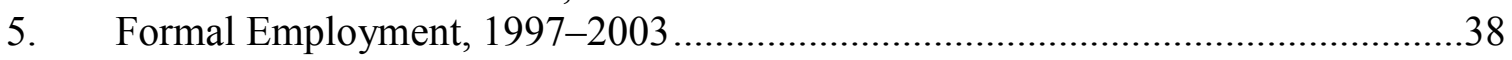

6. Summary of Central Government Budget, 1997-2003 …....................................39

7. Central Government Revenue and Grants, 1997-2003 ......................................40

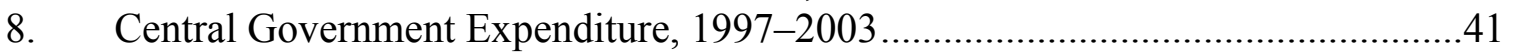

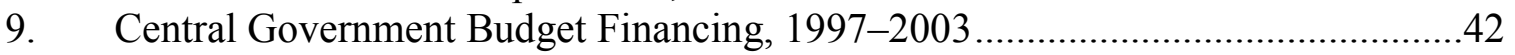

10. Central Government Gross Domestic Debt, 1997-2003 ......................................43

11. Equity Investment of the Investment Corporation of the Solomon Islands,

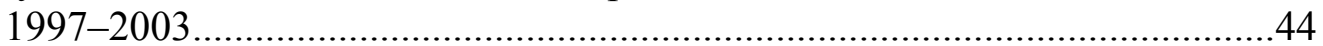

12. Summary Accounts of the Banking System, 1997-2003 .....................................45

13. Assets and Liabilities of the Central Bank of the Solomon Islands, 1997-2003 ....46

14. Assets and Liabilities of Commercial Banks, 1997-2003 ..................................47

15. Commercial Bank Advances and Loans, 1997-2004 ........................................48

16. Commercial Bank Interest Rates on Savings and Time Deposits, 1997-2004 .......50

17. Commercial Bank Interest Rates on Loans and Overdrafts, 1997-2004 ................51

18. Assets and Liabilities of the National Provident Fund, 1997-2004 ......................52

19. Income Statement of the National Provident Fund, 1998-2003 ...........................53

20. Assets and Liabilities of the Development Bank of the Solomon Islands,

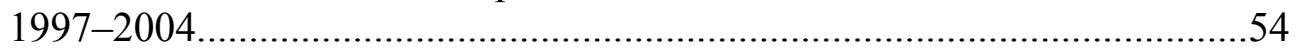

21. Income Statement of the Development Bank of the Solomon Islands,

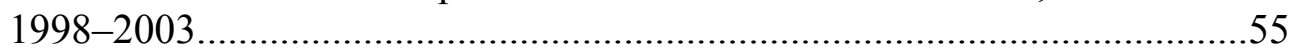

22. Balance of Payments, 1997-2003 (in millions of Solomon Islands dollars) .........56

23. Balance of Payments, 1997-2003 (in millions of U.S. dollars) ............................57

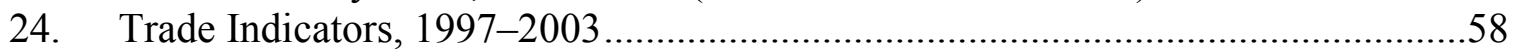

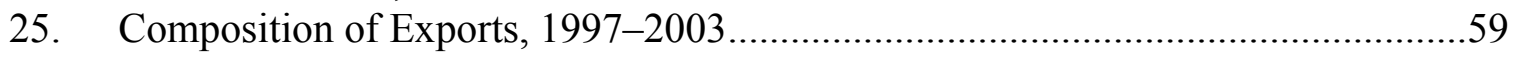

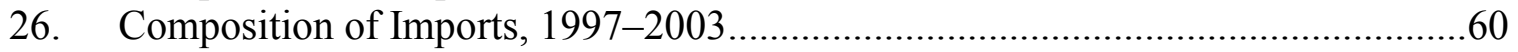

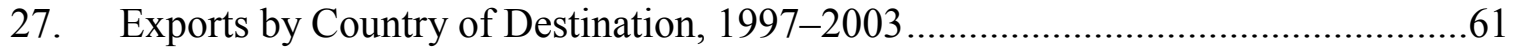

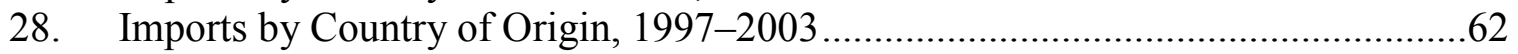

29. Services, Income, and Transfers, 1997-2003 ...................................................63

30. Medium- and Long-Term Government External Debt and Disbursements, 1997-2003.

31. Medium- and Long-Term External Government Debt-Service Payments, 1997-2003.

32. Medium- and Long-Term External Debt Indicators, 1997-2003 ..........................66

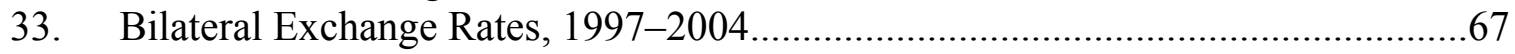

34. Exchange Rate Indicators, 1997-2004 .............................................................68 


\section{Prospects for Increasing Growth and Reducing Poverty ${ }^{1}$}

1. Since gaining independence in 1978, the Solomon Islands economy has not generated sustained increases in per capita GDP. For twenty years, average living standards were closely linked with the pace of resource extraction and hence were vulnerable to fluctuations in world commodity prices, while a population growth rate of more than

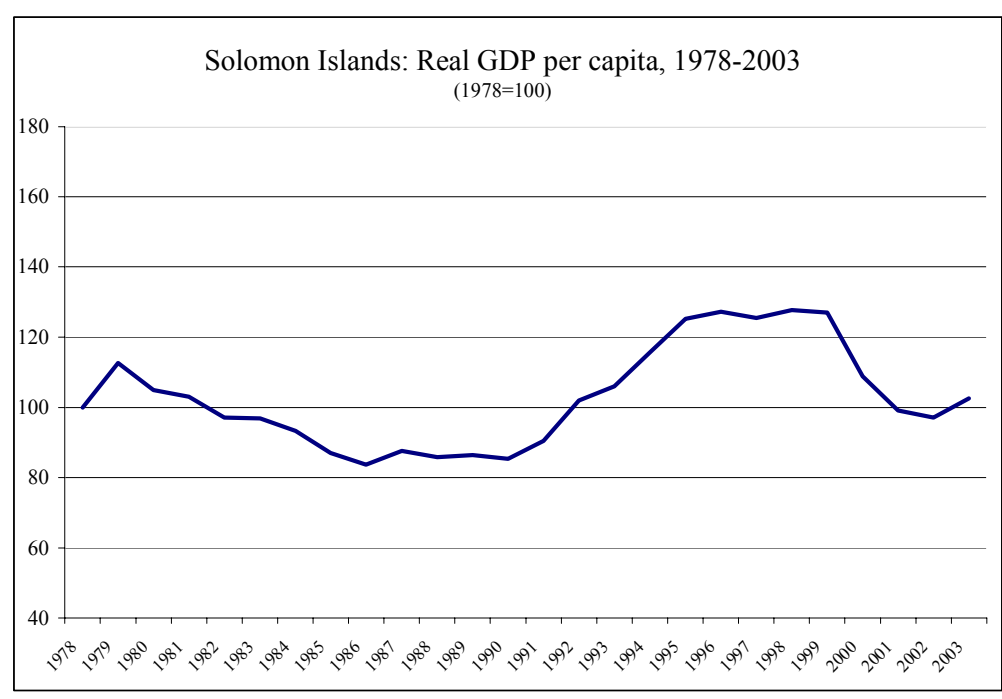

3 percent a year put pressure on the resource base. The growth performance in the 1980s was poor due to the combination of adverse terms of trade movements and natural disasters. During the first half of 1990 s, the average annual per capita growth rate reached 4 percent, but this was mainly driven by unsustainable increases in the felling and export of logs. Budget deficits hovered around 7 percent of GDP, and the consequent build

up in public debt put pressure on the financial system. Growth was already subsiding when the Asian crisis occurred and commodity prices took a sharp downturn.

2. The recent, and larger, negative impact on the economy followed the outbreak of a violent internal conflict in mid-1999 (Box I.1). Private sector activity contracted due to the threat to security of persons and property, macroeconomic instability, and the deterioration in the provision of government services. Real GDP declined by a quarter between 1999 and 2002, and exports and international reserves fell sharply. As budget revenues declined, the government was unable to meet its expenditure and debt servicing obligations. The budget was further pressured by demands for "compensation payments" by armed militants that had been employed in the police force under the October 2000 peace agreement. Unable to stop the downward spiral of violence and the breakdown of governance, the government and the parliament invited a nine-nation force, led by Australia, to intervene in July 2003 in order to restore law and order and strengthen administrative capacity.

3. The civil conflict further worsened social indicators in the Solomon Islands. The country ranked below most Pacific island countries in the United Nations Human Development Index, coming in at 123 out of 175 countries in 2002. Malaria is rampant, with the highest rate of infection in the world outside of sub-Saharan Africa, and more than a third

${ }^{1}$ Prepared by Engin Dalgic (ext. 38771). 
of the rural population lack access to safe water. The more extreme forms of poverty, such as malnourishment, have been contained in the Solomon Islands thanks to the rich resource base, access to customary land supporting subsistence production, and resilient social networks. These advantages, however, are being eroded by the rapid population growth. Primary education is not compulsory, and the payment of school fees is a significant burden on the poor. The enrollment ratio is 80 percent at the primary education level, but is only 30 percent at the secondary level.

\section{Box I.1. Solomon Islands: Civil Conflict and the Multilateral Intervention}

The Solomon Islands faced significant civil violence between 1999 and 2003 . The indigenous majority on the island of Guadalcanal harbored animosity against migrant workers from the island of Malaita, based on the perception that Malaitans enjoyed greater success in securing jobs in large enterprises, such as the Gold Ridge mine and palm oil plantations. Resentment was also fueled by the migrants who squatted on the land of indigenous Guadalcanal landholders.

In mid-1999, bands of armed militants from Guadalcanal intensified attacks on workers of Malaitan descent. A number of Malaitan militia groups were formed that launched retaliatory attacks, while 20,000-30,000 Malaitans fled Guadalcanal. Violence intensified and, in early June 2000, a Malaitan militia group staged a coup that led to the ousting of the Prime Minister. The government and the warring groups signed a peace agreement in October 2000 in Townsville, Australia. As a provision of the agreement, militiamen were given employment as "special constables" on the police force, which ultimately diminished control by the government over the security situation. Violent confrontations and claims for cash "compensation" from the central government became endemic, and the election of a new parliament at end-2001 proved ineffective in countering the prevailing atmosphere of lawlessness.

At the request of Prime Minister Kemakeza, in July 2003 a regional multilateral force led by Australia arrived in the Solomon Islands. The intervention force (termed RAMSI) received the backing of all sixteen members of the Pacific Islands Forum, and included military and/or police contingents from Australia, New Zealand, Papua New Guinea, Fiji, Tonga, Samoa, Vanuatu, Kiribati, and the Cook Islands among its 2,000 plus members.

The intervention has achieved its immediate objective of securing law and order. Most of the people involved in the hostilities have been arrested, including Harold Keke, leader of the only militia group not to sign the Townsville peace agreement. A gun amnesty has resulted in the collection of 3,700 weapons. The police force is being restructured, with 800 special constables demobilized by end-2003, and many members of the force that were believed to be linked with the illegal groups have been arrested. While there is no fixed schedule for the withdrawal of the military force, the number of troops was halved by end-2003 given the success of initial efforts and a further reduction scheduled for 2004 has been announced. The 300 foreign police officers stationed in the Solomon Islands are expected to remain in place for several years.

RAMSI is also working to restructure the public sector management and improve governance. Sixteen Australian experts have been placed in key positions in the Ministry of Finance, including the Undersecretary and the Accountant General, to improve the control and accountability of public expenditure. Experts are also assisting in restructuring public debt and reforming the Tax and Customs Administrations. 


\section{A. Sectoral Problems}

\section{Agriculture}

4. Averaging about 20 percent of GDP throughout the 1990s, agriculture constitutes the largest sector of the Solomon Islands economy. The main cash crops are coconut, cocoa, and oil palm, which have the potential to bring significant export revenues. However, the share of agricultural products in total exports fell from around one-fifth in the second half of the 1990s to just 7 percent in 2002, due to the closure of the oil palm plantations, the sharp fall of world copra prices, and the collapse of the domestic copra marketing agency. ${ }^{2}$ Agricultural exports recovered to 10 percent of total exports in 2003, led by buoyant cocoa exports.

5. The economic and social significance of the agricultural sector is larger than its share in GDP suggests - since more than 80 percent of the population lives in the rural areas-and most agricultural output is for subsistence consumption. Small producers also generate marketable surpluses of cash crops, primarily copra, that supplement their livelihoods. However, there are a number of difficulties facing these small producers.

6. One of the most formidable impediments is limited market access. The Solomon Islands is a geographically dispersed archipelago spanning 1,500 kilometers, and the infrastructure for transport in and between the islands is inadequate. To access regional markets, the only available transport method for many farmers is canoes with outboard engines given the scarcity of roads and regular shipping lines. High fuel costs and the limited capacity of canoes limit the profitability of producing for market. Private companies that entered the market to collect copra from rural areas after CEMA's right to undertake monopoly purchases was finally abolished in 2002 have faced the same constraints.

7. The lack of credit opportunities is another impediment to farmers' efforts to increase their productive capacity. The Development Bank of Solomon Islands-a government agency established to provide credit to rural producers is insolvent and has closed virtually all its rural branches. The National Bank of Solomon Islands serves only some of the provincial capitals, and the minimum loan limits are beyond what most rural producers need. The European Union recently started providing small grants for selected projects, but there is currently no micro-finance operation.

8. Small producers also lack support on technical issues such as new varieties suitable to their lands and efficient growing methods. The consequent narrowness of the agricultural base poses risks to rural incomes through the volatility in world prices. When

${ }^{2}$ The former monopoly marketing agency, the Commodities Export Marketing Agency (CEMA), was instituted in the colonial era to collect and market copra. Due to mismanagement, it fell into financial disarray and closed its rural collection centers in 2000 . 
world copra prices declined by half between 1999 and 2001, copra production for market fell to practically zero, although this decline was also precipitated by the civil conflict.

9. In contrast to small-scale production, large-scale plantations and targeted toward export markets. Plantations produce oil palm, in addition to coconut palm, which requires large-scale production and processing facilities in order to be economically viable. Plantation investments have been low due to the difficulty in acquiring land. The small and mountainous terrain of the Solomon Islands does not offer many plots suitable for large-scale agricultural production, while the legal status of the land makes it difficult to attract new investment (Box I.2). Since the 1970s, the share of output from plantations in total agricultural output has declined following attempts by CEMA to bolster smallholder production. More recently, the two largest plantations - which employed close to 3,000 people-were closed in the aftermath of the conflict. The government is currently considering a list of potential investors to purchase its own shares in the two plantations as well as those of a foreign partner that has decided to diversify away from agricultural plantations. Experts estimate that it will take a new operator about 18 months to rehabilitate the oil palm trees and resume production.

\section{Forestry}

10. The felling and export of logs has been a major activity in the Solomon Islands, especially in the 1990s, and logging activity was relatively unaffected by the turmoil in 1999-2003. Log exports averaged close to 60 percent of all exports during the 1990s, and the share of $\log$ export duties in recurrent government revenue averaged 15-20 percent a year.

11. Logging levels during most of the 1990s far exceeded estimates of the rate that will keep the existing size of commercially exploitable forests constant. The level of extraction in 2003, which exceeded 700,000 cubic meters, is about three times the estimated sustainable rate. At such high levels of extraction, commercially valuable forests will be depleted as early as $2010-15 .^{3}$

12. The rapid pace of logging reflects economic rents enjoyed by logging operators due to weak property rights and the loopholes in the tax system. Since there is no comprehensive registry of landownership, operators often compensate an individual rather than the collective body of owners. Proportional taxes, which are currently used, are not well suited to the task of extracting rents given the high volatility in the price of timber. Moreover, misreporting the kind of logs exported is pervasive, since the current system bases duties on the species of the log rather than the invoice price. For example, the share of total log exports categorized as "unspecified"- the category with the lowest tax rate-increased from 5 percent to 40 percent between 1996 and 1998.

\footnotetext{
${ }^{3}$ The most recent estimate of the sustainable rate of extraction and extinction date was based on a 1992 survey of the forested area.
} 


\section{Box I.2. Solomon Islands: Land Tenure}

The bulk of land in Solomon Islands is communally owned, as in most Pacific island countries. Comprising 85 percent of the total, such land belongs to tribes and clans rather than individuals, and its ownership is not transferable. Usage rights are determined by local customs, which exhibit a great variety among, and even within, islands. There is no formal registry that matches land to the tribes owning it.

Communal land can be leased to foreign investors, but only with the government acting as an intermediary. The lease process is long and cumbersome. There are three kinds of potential disputes: between tribes, as to which tribe a plot belongs customarily; among the tribe, as to how to execute and share the benefits of the lease contract; and between the tenant and landowners. Disputing members and tribes can appeal any contracts already made. Renegotiation is in many cases inevitable.

The courts are overburdened by land disputes, and are often ill-equipped to handle the intricacies of customs. The court decisions frequently fail to end controversy, because the court assigns a member of the tribe as the sole authority for dealing with the land "on behalf of the tribe." Abuse of this power can cause continued disputes among the tribe, which endangers land development.

The remaining land (15 percent of the total) comprises urban areas and large agricultural plantations, and ownership of this land is registered and transferable. This comprises mostly land taken over by the colonial era government under a Vacant Lands Act, determined to be unoccupied and unused at that time. Subsequently, plots of this land were sold or leased to urban dwellers or companies. Most of the registered land, though, is already developed, and not suitable to accommodate new investment.

Registered land has continued to be a matter of political controversy. Customary owners of registered land dispute the colonial government's earlier decisions, and subsequent governments have gradually returned some of the alienated lands to the original owners.

The existing state of affairs is a constraint to economic growth. The absence of secure titles, and the extended process of negotiation and renegotiation of lease contracts, discourages land-based development. Investment, especially in mining, agricultural plantations, and tourism sectors, is discouraged by the uncertainty surrounding the issue of land rights. Owners are not able to develop their lands either, since they can not use their land as collateral against loans from commercial banks.

Efforts to reform land tenure is underway. A taskforce appointed by the government has prepared a reform proposal where all land will be registered in their customary owners' (tribes) name, and ownership rights will remain non-transferable. Elders of the tribe would be recognized as the authority to negotiate leases and manage the sharing of benefits, subject to appeal by other members in formal courts.

13. Forestry plantations may pave the way to sustainable logging, but they are at an early stage of development. There are two large forest plantations in the Solomon Islands, which supplied 10 percent of total log exports in 2003. The Kolombangara Forest Plantation Limited has access to a market niche for timber extracted through environmentally-conscious practices, thanks to its certification with international monitoring bodies. The other plantation 
is owned by a Korean wood products manufacturer. Small producers are starting to engage in commercial reforestation activity with the help of technical assistance.

\section{Fisheries}

14. Solomon Islands has large fish resources, and the fisheries sector accounted for an average of 7 percent of GDP and 30 percent of total exports in the 1990s. The share of fish in total exports declined to half that figure in the period 2000-03 after the largest fishing company suspended operations. The fisheries sector also makes a modest contribution to budget revenue through license fees for the foreign vessels operating in the Solomon Islands Exclusive Economic Zone.

15. Artisanal fishing has the potential to create a cash-income livelihood for a large number of people, given the mainly coastal settlements. However, as for copra production, market access remains an issue, especially for remote islands. A 1999 census found that 70 percent of all households (excluding Honiara) had fished or collected other marine products for subsistence, while only 30 percent had sold any marine output. The difficulties in marketing are also evident from the fact that most of the fish consumed in Honiara is of the canned and frozen variety. In an attempt to assist small fisherman, rural fisheries centers were set up to provide technical assistance and a marketing facility, with assistance from the European Union and other donors. The project was of limited success with only 6 of the original 30 centers still operating, because they did not reach financial self-sufficiency and lacked skilled management.

16. The commercial fishing companies have problems competing in world markets because of high transport costs to the main export markets. There is no direct air route from the Solomon Islands to the largest markets for fresh and frozen tuna in Asia (Hong Kong SAR, Japan, and Taiwan Province of China). Two large-scale companies account for the bulk of the fish output and exports, and the government-owned company enjoys various tax and other concessions that disadvantages the other operator.

\section{Mining}

17. The Solomon Islands is well-endowed in mineral resources. There is a rich gold deposit in Guadalcanal, which was mined for two years until its closure in mid-2000 due to the civil conflict. Gold exports from this mine constituted a quarter of all export earnings in 1999. There is also firm evidence of nickel deposits on the Isabel Island, and various prospecting activities for copper, oil, and diamonds are continuing.

18. However, the closure of the Gold Ridge mine in 2000 exemplified the considerable risks involved in mining activity in the Solomon Islands. Despite the agreement on a package of resettlement and royalties with the 1,200 people dislocated by the mine, a wider group of Guadalcanal residents took issue with the environmental risks, the migrant workers, and the rent-sharing arrangements between the central and provincial governments, creating one of the underlying tensions associated with the civil conflict. It is unlikely that the Gold Ridge mine will return to operation soon; the landowners' demand 
payment of rents for the period since the closure of the mine and some of the mine's capital equipment has been looted. The mine now belongs to the insurance company that underwrote the political risk policy for the mine. Similarly, a Canadian-based mining company was in the process of raising capital to start mining for nickel on the Isabel Island, when disputes with landowners emerged. The company holds only a license for prospecting, and would need to come to an agreement with the landowners in order to receive a mining license.

\section{Tourism}

19. The Solomon Islands has the potential to become a significant tourist destination in Asia. It has pristine coral reefs (including a UNESCO World Heritage Site), spectacular lagoons, rainforests, and a rich culture. It is suitable for a wide range of outdoor activities, and opportunities for diving are highly valued. Comparison with other Pacific Island countries suggest that tourism in the Solomon Islands is well below potential. For example, Vanuatu enjoys around 50,000 tourist arrivals a year whereas the Solomon Islands has never exceeded half that amount, even at its peak in 1993. After the conflict, security concerns brought the already underdeveloped tourism industry to a halt.

20. The existing level of tourism facilities is far from sufficient, and a weak infrastructure, coupled with the shadow of the violent conflict, makes large-scale development unlikely in the short term. Inter-island transport, airport facilities, and ports are inadequate. Most of the tourism industry is located in Honiara and as such eschews the spectacular natural attractions of the outlying regions. In addition, international and domestic air travel is infrequent and expensive. For example, a round-trip ticket for the three-hour flight from Brisbane to Honiara (2,100 kilometers) costs around US\$1,000.

21. While several ecotourism projects are supported by the donor community, the scale of these activities is limited by design. Donors have provided support for ecotourism in the hope that these projects would enable the protection of the environment by providing cash income to rural communities to reduce their reliance on unsustainable logging activities. They are especially valuable for remote communities, but the income generated by ecotourism projects has remained limited due to their small scale in addition to the general impediments noted earlier.

\section{Manufacturing}

22. Manufacturing is of limited scale in the Solomon Islands, averaging 4 percent of GDP, and mainly consists of processing fish and agricultural commodities such as coconut oil and palm oil extraction, most of which is exported. There are manufacturing concerns of smaller scale such as sawmilling and a tobacco factory producing for the domestic market. The palm oil mill and fish cannery were closed due to the conflict. The cannery is now operating at half-capacity, and the government is looking to devolve its share or find a new partner to replace the Japanese partner that left in 2001. An Australian-owned bakery, employing 120, was sold in late 2003, in accordance with a change in the holding firm's strategy. 
23. Unreliable public provision of services such as electricity, lack of skilled personnel, and security issues have been the major impediments to attract new investment to the manufacturing sector. The small size and dispersion of the domestic market does not encourage large-scale manufacturing. In addition, foreign manufacturers are not allowed to engage in retailing, obliging them to use existing retailers, and creating a disincentive to produce for the domestic market.

\section{B. Facilitating Growth}

24. The current favorable law and order environment provides an opportunity for the Solomon Islands to embark on an ambitious reform strategy aimed at raising per capita growth in the urban and rural areas. In the short term, donor-facilitated public sector investment can serve as the main driving force of economic growth. However, as aid is scaled back, sustaining economic growth will require rapid expansion of private sector investment. The reforms necessary to achieve a high and sustainable rate of private sector-led growth and an improvement in living standards involve the following aspects: establishing a macroeconomic environment conducive to investment, reallocating government expenditure toward productive areas in order to provide the necessary infrastructure and government services for private sector activity, and other structural reforms including strengthening governance to underpin permanent improvements in the investment climate.

25. On the macroeconomic front, containing the fiscal deficit through expenditure restraint and enhancing revenue collection is a priority. Financing of the high deficits had put a strain on the economy and discouraged private investment. Borrowing from the central bank and the financial sector accelerated the rate of inflation and crowded out private sector investment. Once borrowing opportunities were exhausted, the government resorted to running arrears on expenditure and debt servicing, further weakening the financial balances of the private sector and the state owned enterprises. A broadly balanced budget will help regularize payments to suppliers and creditors of the government, sustain the current low rate of inflation, and expand credit opportunities for the private sector.

26. The rehabilitation of infrastructure is necessary to provide essential services to households and businesses. Infrastructure in the Solomon Islands was damaged extensively during the turmoil because of the immediate effects of the conflict and a lack of maintenance. Inter-island shipping is scarce, roads are in a poor state, and power outages are a regular occurrence. Agricultural and fisheries sectors would benefit from the consequent expansion of market access, while tourism and mining sectors would be more likely to attract new investment. The 2004 development budget provides limited funds for infrastructure spending only: about 10 percent of funds committed by the donors are earmarked for infrastructure, with the bulk allocated towards health and education outlays. As the government consolidates its financial position, and donors diversify their focus, a shift toward infrastructure investment could be an important element to ensure sustainable high rates of economic growth. 
27. It is also imperative to increase the provision of basic social services such as health and education. Shortcomings in social indicators, while amenable to improvement through economic growth, are a fundamental hindrance to growth in itself. For example, the very high incidence of malaria in the Solomon Islands, apart from causing immense human suffering, appears in many countries' travel advisories (limiting tourism and foreign direct investment), decreases labor productivity, and discourages domestic mobility. Lack of human capital is also a disincentive for local and foreign investors. Better provision of social services should be underpinned by more than just increased funding. For example, the extreme concentration of public employment in administrative tasks and in Honiara limits the availability of public services in other areas of the country. Extending the provision of public services to the rural poor requires reallocating the workforce and increasing the proportion of front line workers (e.g., teachers, nurses, and agricultural extension workers) relative to administrators. Similarly, social spending should be focused on preventive health care and primary education to make the largest impact on poverty.

28. Provision of agricultural extension and information services to the rural sector is another area where government expenditure could be productive. Diversification of the agricultural base can play an important role in decreasing the vulnerability of the rural population and providing an impetus to higher export receipts. A recent successful effort to introduce seaweed in the Solomon Islands, which requires low initial investment and has a secure export market, has shown that there are market niches that can be exploited even in a difficult environment. A household survey in the Western province indicated that seaweed has become the primary cash crop grown.

29. Credit availability to the rural sector will need to be expanded to support the market-oriented agricultural production. Typically, rural producers require small loans but have no collateral given the absence of individual titles to land. Micro-finance may be an appropriate method of extending credit in these circumstances, and the existing social networks can facilitate group lending in which successive loans to members are conditioned on repayment by each member.

30. The bureaucratic and regulatory environment faced by investors needs to be improved (Box I.3). Simpler and more transparent regulations would help current operators be more efficient, encourage new entrants, and enhance competition. Complex and arbitrary regulations exacerbate poverty by stifling growth and employment opportunities and by creating inequities in available information and connections.

31. An important component of efforts to encourage urban sector activity is reform of public enterprises to ensure a reliable supply of utility services. Public enterprises face financial and operational problems, and interruptions of service remain a frequent occurrence. Low cash collection rates, partly due to government arrears, and tariffs that are inadequate to cover recurrent costs, have caused a deterioration in their financial situation. The government has started paying for its current usage and is about to start to clear some of the arrears. Donors are also providing technical assistance and needed capital equipment. However, tariffs need to be increased further, and the enterprises need to streamline their 
operations, cut costs, and develop plans for regular maintenance of their infrastructure. Enhancing the quality and independence of their Boards would also help provide a more effective management.

\section{Box I.3. Solomon Islands: Regulatory Environment for Investors}

The regulations governing private sector investment in the Solomon Islands are not only overly restrictive, but often applied arbitrarily. Some of the more significant impediments to investment are the following:

- The Honiara City Council requires an excessive list of permits for private businesses to operate in the city. Specific permits are necessary for selling many categories of merchandise. For example, a gas station reportedly was required to furnish ten separate permits to cover gas sales, repairs, selling spare parts and sales of other retail products such as ice cream. Moreover, there is no published schedule for these fees.

- All foreign investment needs to be approved by the Foreign Investment Board. The process takes more than a year in most cases, and the criteria are non-transparent. Investors need to apply separately for further licenses, e.g., to the city council, provincial government, and for fisheries licenses. The Board often recommends (to a special committee) a new investment be granted extensive tax holidays (up to 10 years), disadvantaging already established operators.

- The shortage of skilled workers is exacerbated by the difficulty of getting labor permits for foreign workers, a process which involves providing evidence that no Solomon Islander has the specific skills for the position concerned, and assuring that the firm will train a Solomon Islander to take up the post in due course.

- Customs processing is slow, and export duties add to bureaucratic complexities while bringing negligible fiscal revenue (accounting for 0.01 percent of GDP in the period 2000-02, excluding those for logs).

The government has started to address the regulatory issues. The need to review the current regulation of foreign investment was identified in the National Economic Recovery, Reform, and Development Plan, and Australia and the World Bank's Foreign Investment Advisory Service (FIAS) are providing assistance for that purpose. Consultations with stakeholders on the elements of a new foreign investment policy are ongoing and customs procedures are being overhauled, also with donor assistance.

32. Improving the quality of governance is also important. Steps in this direction should include increasing transparency in government actions, and bolstering checks and balances, including an assurance of a free press and an independent judiciary. Efforts to strengthen governance in key areas such as the judiciary and policing have already started, and monitoring institutions such as Leadership Code Commission, Ombudsman, and Auditor General are being strengthened.

33. Bringing the pace of logging back to a sustainable level is another challenge. The forestry sector has been marred by weak enforcement of rules and questionable tax exemptions. Strengthening the administrative capacity of the enforcing agencies (e.g., the 
Forestry Board and Customs Administration), and freezing new licenses and exemptions, would be initial steps in the reform of the sector, as would reevaluation of outstanding licenses. In the medium term, plantation forestry could assist in ensuring a sustainable logging industry and the preservation of natural forests. The recent expansion of large plantations and smaller household enterprises is encouraging, and needs to be supported by simplified tax regulations and information and extension services.

\section{Finally, land reform is a medium-term challenge that has the potential to} invigorate many sectors, but especially agriculture, tourism, and mining. Technical assistance from outside agencies that have experience in land reform projects throughout the region, and an open and consensus-based domestic planning process, can help the Solomon Islands overcome this challenge. 


\section{State OF THE FinANCIAL SECTOR ${ }^{1}$}

1. The financial sector in the Solomon Islands has come under increasing stress over the past decade. Following the large government borrowing in the early 1990s, the subsequent debt default in 1996, and the outbreak of social tensions in mid-1999, the level and quality of the loan portfolios of financial institutions has deteriorated. While their balance sheets were weakened, the commercial banks have, nonetheless, been able to compensate for shortfalls in their income from lending activities by enhancing their earnings from foreign exchange transactions. In contrast, the largest government-controlled nonbank institutions, notably the National Provident Fund and the Development Bank of Solomon Islands, have experienced severe difficulties, in terms of both their balance sheets and liquidity position. These difficulties have only recently started to be addressed.

\section{A. Financial System Assessment}

2. Despite the small size of its economy, the Solomon Islands' financial system is diverse, consisting of a banking system and a number of nonbank financial institutions. The banking system comprises the Central Bank of Solomon Islands (CBSI) and three commercial banks. The nonbank financial sector includes the National Provident Fund (NPF), the state-owned Development Bank of the Solomon Islands (DBSI), and a number of specialized institutions (credit unions, insurance, and housing schemes).

3. Total assets of the financial system have been around 85 percent of GDP and are spread roughly equally among the central bank, the commercial banks, and the main nonbank institutions. The stock of commercial bank assets has hovered around 30 percent of GDP (the domestically-owned National Bank of Solomon Islands accounts for half of these assets), central bank assets at 22 percent of GDP, NPF assets at 24 percent of GDP, and DBSI assets at 3 percent of GDP.

\section{Central Bank of the Solomon Islands (CBSI)}

4. Under the Central Bank Act, the CBSI is independent of the government and responsible for conducting the country's monetary and exchange rate policies to foster balanced economic growth and to develop and promote financial stability in the Solomon Islands. The weak fiscal policy in recent years has led to a marked deterioration in the quality of the CBSI's balance sheet and its profit and loss account. The bulk of the CBSI's assets are foreign exchange reserves, the level of which declined rapidly during the period of civil conflict as money demand dropped sharply, and lending to central government, all of which has been in default. As a consequence, CBSI profits have declined from positive SI\$2.5 million in 1998 to negative SI\$7 million in 2002. Following the decision by the CBSI's Board to fully provision against the non-performing government assets, the CBSI

\footnotetext{
${ }^{1}$ Prepared by Philippe Marciniak (ext. 36732).
} 
recorded a net liability of SI\$53 million in 2002, and the government has not replenished the CBSI's capital base as required under the Central Bank Act. Due to the increased level and valuation of its foreign exchange holdings in 2003, the CBSI's net liability improved somewhat to negative SI\$28 million, and its loss position declined to SI\$5 million, in 2003.

5. Given this weak balance sheet and profit and loss account, the CBSI has found it difficult to manage excess liquidity within the banking system, which has now reached 20 percent of deposits, and provide an orderly foreign exchange market. The CBSI has not been able to issue its own securities to mop up liquidity since it cannot afford to service the interest cost, and the government default has limited the degree of interest by the commercial banks in purchasing government securities that are sold through the CBSI. In the absence of these indirect instruments, the CBSI has had to rely on the liquid asset requirement (currently 7.5 percent) and, since 2000, has made recourse to exchange restrictions to preserve the dwindling stock of foreign exchange. The increase in the level of international reserves since mid-2003 has enabled the CBSI to remove these restrictions effective April 2004, and the CBSI's ability to undertake open market operations is expected to be greatly improved once the current government debt restructuring discussions have been concluded.

6. The CBSI is also responsible for oversight of the financial sector. ${ }^{2}$ The 1998 Financial Institutions Act equipped the CBSI to supervise licensed financial institutions, including most nonbank entities. Draft prudential guidelines that are in line with the Basle Core Principles were developed with World Bank technical assistance and were issued to commercial banks in 2000 (Box II.1). These guidelines will be submitted to the CBSI Board for final approval in mid-2004.

\section{The CBSI has recently strengthened its supervisory role over the nonbank} sector. The necessary government orders to bring the NPF and DBSI under CBSI supervision were issued in August 2002. The CBSI performed its first on-site inspection of both institutions in late 2003, utilizing foreign technical assistance, and an action plan for both institutions is being drafted. The CBSI is also expected to formally take over supervision of insurance companies from the Office of the Controller of Insurance later in 2004. Credit unions are certified and supervised by the Solomon Islands Credit Union League (SICUL), which undertakes monthly monitoring, annual auditing, and training to credit union staff. However, since SICUL has experienced financial difficulties in recent years, credit union supervision may fall under the CBSI in the near future. The CBSI took legal action in 2003 against the Family Charity Trust, a pyramid scheme, in line with its commitment to combat fraudulent financial schemes.

\footnotetext{
${ }^{2}$ There is no deposit insurance in the Solomon Islands.
} 


\section{Box II.1. Solomon Islands: Prudential Regulations}

Section 8 of the 1998 Financial Institutions Act provides the CBSI with a general framework for prudential regulation. More specific guidance is found in the "Prudential Supervision Policies" that were developed in 1999 with World Bank technical assistance and disseminated to the commercial banks in 2000. These draft prudential regulations are in accordance with the Basle Core Principles. The final version, which was prepared following commercial bank' comments, is expected to be approved by the CBSI Board in mid2004. The main features of the guidelines are as follows:

- Asset Quality. The guidelines address issues related to: (i) the recognition and measurement of impaired assets; (ii) security valuation and provisioning; and (iii) credit risk-grading systems. Nonaccrual items include facilities where contractual payments are 90 or more days in arrears and, more generally, all facilities for which there is reasonable doubt about collectibility. The guidelines provide for a standard credit grading system. Minimum provisions range from 20 percent of the outstanding balance (substandard) to 100 percent (loss), and are to be maintained on non accrual items.

- Capital Adequacy. At least 50 percent of financial institutions' capital must be paid-up (in shares, reserves, and/or retained earnings) with the remainder held in unimpaired reserves (revaluation reserves, general provisions for doubtful debts, and unaudited retained earnings). The 1998 Financial Institutions Act sets the minimum amount of paid-up capital at SI\$5 million for banks and SI\$1 million for credit institutions. Under recently revised draft guidelines, financial institutions would be required to maintain a minimum ratio of total paid-up capital to risk-weighted assets of 15 percent as against the current 10 percent. The CBSI requires a higher ratio for banks with excessive risk exposure or newly established banks.

- Liquidity. Under the recently revised draft guidelines, the CBSI would require financial institutions to maintain a minimum liquid assets ratio of 7 percent of total liabilities as against 7.5 percent currently. Financial institutions are advised to strengthen liquidity management through: (i) limits on maturity mismatching; (ii) diversification of liabilities; (iii) access to the interbank market; (iv) foreign exchange liquidity; and (v) liquidity management among branches and subsidiaries.

- Corporate Governance. The guidelines set standards for Boards and Management to ensure prudent management and prevent conflicts of interest. Senior management should demonstrate that they are "fit and proper."

- Large Exposures. To avoid risk concentration, the 1998 Financial Institutions Act sets a limit of 25 percent of total capital on financial institutions exposure to the same client. However, total exposure to other banks and the government are not subject to a statutory limit.

- External Audit. Financial institutions are required to complete annual external audits and to submit them to the CBSI within three months after the close of their financial year.

\section{Commercial Banks}

\section{The private banking sector is comprised of three commercial banks, all of which provide similar services, although the National Bank of Solomon Islands (NBSI) is the only bank with a substantive branch network outside Honiara. ANZ and Westpac are branches of well-established Australian banks that mainly cater to businesses. Both pose minimal risks to the financial system, as the CBSI holds letters of understanding from the head offices of both banks promising to provide funds to cover all obligations and liabilities incurred by their subsidiaries in the Solomon Islands. The NBSI's ownership status has been}


unclear since the Bank of Hawaii gifted its 51 percent share to three privately-held trusts in 2000. ${ }^{1}$ This transfer of shares was challenged by the CBSI on the grounds that the transfer required the consent of the CBSI, but the challenge was abrogated by the High Court. However, the formal transfer of shares to the trustees requires unanimous consent of the shareholders and directors, and thus far the NPF, which holds 49 percent of the shares of the NBSI, has dissented.

9. The balance sheets of the commercial banks weakened after the outbreak of ethnic tension, but have recently started to recover. In line with the decline in nominal GDP, deposits declined from a peak of SI\$502 million at end-1999 to SI\$470 million at end-2002, before increasing sharply to SI\$572 million at end-2003. The term structure of deposits has increasingly shortened, with demand deposits now accounting for 52 percent of total deposits at end-2003 compared with just 40 percent at end-1998.

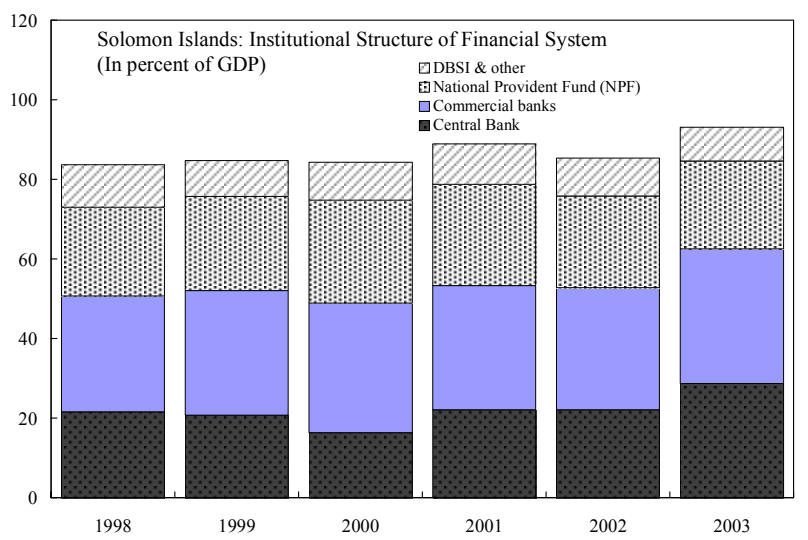

10. Currently, only one-third of total commercial bank assets are for loans and advances, down from two-fifths before the outbreak of the social tensions. Although bank lending covers a wide range of economic activities, the bulk of the lending is for short-term working capital and overdrafts for established businesses focused in the forestry and trade and services sectors. Most private sector loans are at a fixed rate and require collateral in the form of cash or deposits; assets are only acceptable if located on registered land (around 15 percent of total land, primarily in Honiara). Accordingly, start-up businesses in rural areas are largely excluded from commercial bank loans. Non-performing loans (NPLs) have increased in recent years, due in part to the substantial arrears the government has incurred with private companies and state-owned enterprises. Accordingly, lending interest rates have been high (around 15 percent at end-2003), although in recent months they have declined somewhat following the restoration of law and order.

11. Holdings of government securities account for another one-third of commercial bank assets, all of which have been in default since 1996 (Box II.2). Much of the balance of commercial bank assets represents cash deposits held at the CBSI, which have increased from SI\$52 million at end-1998 (11 percent of total commercial bank assets) to SI\$105 million at end-2003 (20 percent). Of this amount, SI\$83 million are holdings in

\footnotetext{
${ }^{1}$ The private trusts are charitable organizations to service the health and welfare sector, the education sector, and for NBSI employees. Each trust fund holds a 17 percent stake in NBSI.
} 
excess of legal requirements for which the banks earn no interest. This reflects the lack of profitable lending opportunities.

\section{Box II.2. Solomon Islands: Government Debt}

Holdings of government debt by the financial sector increased rapidly in the 1990s due to the large budget deficits, the CBSI's prudential requirement that commercial banks hold 40 percent of their assets in either cash or government securities (which was rescinded in 1998), and directed purchases of securities by the nonbank institutions. Following the first default in 1996, the government forcibly rolled over the outstanding stock of (short-dated) treasury bills.

In April 1999, the financial sector institutions were allowed to convert these "frozen treasury bills" into "restructured bonds" that were to be repaid in four annual tranches starting April 15, 2001. Bondholders were given the choice of receiving a fixed rate set at $7 \frac{1}{2}-10$ percent (depending on the length of maturity) or a floating rate of 1-2 percent above a reference rate (initially, the prevailing 6-month commercial bank deposit rate, and later the prevailing treasury bill rate). Following the outbreak of civil conflict in mid-1999, none of these scheduled repayments were made, and in September 2002 the government unilaterally started to pay in cash an interest rate equivalent to 3 percent on the stock of the "restructured bonds," and to accrue the balance of the interest due. The commercial banks won a court order to require the government to repay this debt on its original terms, although this judgment has not been fulfilled by the government given its lack of resources. The government has paid no interest on their overdraft to the CBSI.

Government formal domestic debt at end-2003 stood at SI\$465 million (26 percent of GDP, compared with 20 percent of GDP in 1998). This included SI $\$ 186$ million in the overdraft account held at the CBSI, SI $\$ 150$ million in restructured bonds held by the commercial banks, SI\$94 million held by the NPF in restructured bonds and other forms of government securities, and around SI\$30 million of short-term treasury bills issued through the CBSI for monetary policy purposes for which the cash raised is held in a blocked account at the CBSI. A strategy to restructure all but the last of these government debt obligations is under preparation, with foreign technical assistance.

12. Despite the significant exposure of the banks to non-performing government debt and the high level of excess liquidity, commercial banks have maintained adequate operating profits (Table II.1 and Figure II.1):

- Operating income declined after the outbreak of violence in 1999, but increased in 2002-03. Net interest earnings fell during 1998-2003 as the decline in deposit rates (to around 1 percent a year, although deposit rates are higher for large customers) did not fully offset the decline in banks' income from government securities, increase in private sector NPLs, limited new lending opportunities, and zero interest income earned from excess cash deposits. In contrast, non-interest earnings, especially from fees and charges on deposit activity and from the wide bid/ask spreads on foreign exchange transactions, have been substantial, with their share in total operating income rising from 43 percent in 1998 to 65 percent by 2003 .

- Bank profitability was also maintained, reflecting the rising level of noninterest income and the containment of operating expenses. Net profit (before tax) increased to 32 percent of operating income in 2003, compared with 26 percent in 1998, and the return on assets reached 5.1 percent in 2003 against 3.2 percent in 1999. 
Table II.1. Solomon Islands: Financial Soundness Indicators of Commercial Banks, 1998-2003 (In percent)

\begin{tabular}{|c|c|c|c|c|c|c|}
\hline & 1998 & 1999 & 2000 & 2001 & 2002 & 2003 \\
\hline \multicolumn{7}{|l|}{ Sectoral distribution of private sector loans } \\
\hline Agriculture, forestry, and fisheries & 8.9 & 10.5 & 16.4 & 12.7 & 13.4 & 22.3 \\
\hline Manufacturing and mining & 14.9 & 17.7 & 27.9 & 27.3 & 25.7 & 14.8 \\
\hline Trade and services & 42.7 & 33.3 & 25.2 & 30.4 & 35.1 & 40.9 \\
\hline Personal & 28.3 & 34.3 & 25.2 & 23.3 & 19.7 & 15.8 \\
\hline Other & 5.3 & 4.2 & 5.3 & 6.3 & 6.1 & 6.3 \\
\hline \multicolumn{7}{|l|}{ Capital adequacy } \\
\hline Regulatory capital to risk-weighted assets & 20.4 & 22.6 & 25.4 & 30.4 & 28.2 & 27.7 \\
\hline Capital to assets & 13.8 & 14.4 & 15.4 & 19.4 & 20.0 & 16.9 \\
\hline \multicolumn{7}{|l|}{ Asset quality } \\
\hline Nonperforming loans to total gross loans & 3.5 & 3.8 & 6.6 & 12.4 & 11.3 & 8.3 \\
\hline Nonperforming loans net of provisions to capital & 9.7 & 10.1 & 15.7 & 19.8 & 18.9 & 12.7 \\
\hline Provisions to nonperforming loans & 85.8 & 57.4 & 43.0 & 32.3 & 32.4 & 53.2 \\
\hline Household debt to GDP & 3.2 & 4.1 & 3.2 & 2.5 & 2.2 & 2.0 \\
\hline \multicolumn{7}{|l|}{ Earnings and profitability } \\
\hline Return on assets (net income to average total assets) & $\ldots$ & 3.2 & 2.9 & 3.3 & 4.5 & 5.1 \\
\hline Return on equity (net income to average capital) & $\ldots$ & 23.0 & 19.7 & 18.8 & 22.6 & 27.8 \\
\hline Net interest income to gross income & 57.2 & 57.9 & 60.5 & 56.4 & 42.9 & 34.9 \\
\hline Non-interest income to gross income & 42.8 & 42.1 & 39.5 & 43.6 & 57.1 & 65.1 \\
\hline Of which: Forex income & 32.8 & 31.7 & 30.5 & 33.3 & 45.7 & 52.5 \\
\hline Non-interest expenses to gross income & 48.9 & 51.9 & 58.6 & 57.4 & 54.4 & 50.1 \\
\hline Net profit to gross income & 26.4 & 24.9 & 26.2 & 28.1 & 29.3 & 31.7 \\
\hline Personnel expenses to noninterest expenses & 40.9 & 44.6 & 42.9 & 47.8 & 38.6 & 41.2 \\
\hline Spread between reference lending and deposit rates & 10.9 & 10.9 & 12.1 & 14.1 & 15.0 & 14.6 \\
\hline \multicolumn{7}{|l|}{ Liquidity } \\
\hline Liquid assets to total assets & 11.4 & 10.4 & 12.3 & 14.3 & 13.0 & 18.4 \\
\hline Liquid assets to short-term liabilities (demand deposits) & 35.6 & 29.2 & 36.9 & 39.5 & 39.2 & 53.1 \\
\hline Deposits to total loans & 204.1 & 190.3 & 189.7 & 204.4 & 180.3 & 197.4 \\
\hline Liquidity ratio (liquid assets to total deposits) & 14.2 & 14.1 & 16.1 & 20.4 & 19.1 & 27.7 \\
\hline
\end{tabular}

Sources: Central Bank of Solomon Islands; and Fund staff estimates. 
Figure II.1. Solomon Islands: Commercial Banking Environment
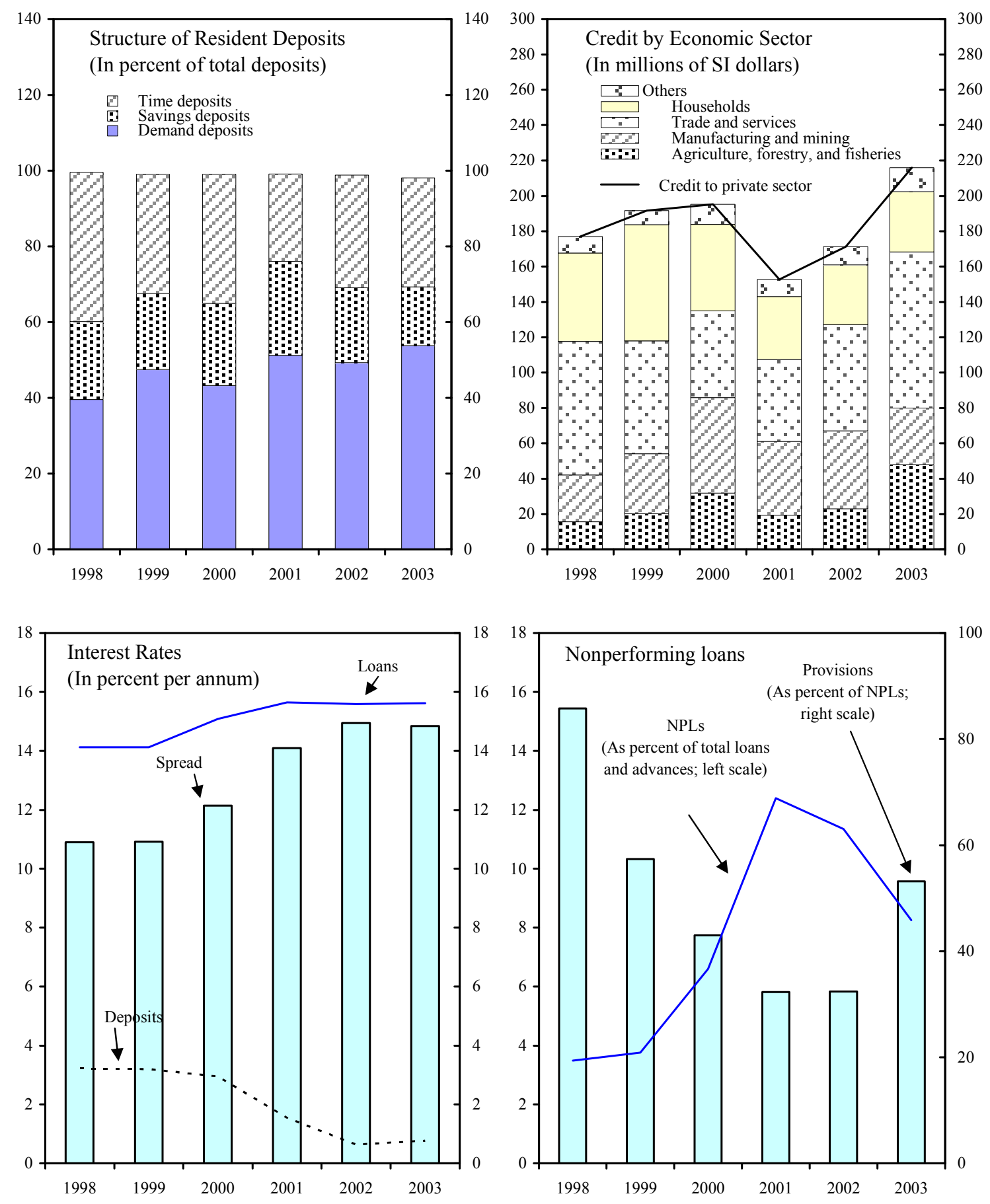

Sources: Solomon Islands authorities; and Fund staff calculations. 
- Asset quality, as measured by NPLs, has deteriorated since 1998 in view of the civil conflict, rising from SI\$6 million in 1998 (3 percent of private sector loans) to SI\$20 million in 2002 (11 percent), before falling back to SI\$16 million (8 percent) in 2003. Moreover, while provisions against NPLs have increased to 53 percent in 2003, no provision has been taken for the government assets in the commercial banks' balance sheets.

- Capital adequacy, as measured by risk-weighted assets, was maintained throughout the period at levels well above the 10 percent prudential requirement (currently 28 percent). All the banks hold capital that far exceeds the required minimum level (SI\$5 million), reflecting the perceived high risk associated with banking activities in the Solomon Islands.

- Liquidity requirements were met during 1998 to 2003. The liquidity ratio (liquid assets to total deposits) increased from 14 percent in 1998 to 28 percent in 2003 . While primarily representing the lack of lending opportunities, this high level has strengthened the ability of banks to withstand shocks arising from economic turnarounds or from any surge in deposit withdrawals.

\section{National Provident Fund (NPF)}

\section{The National Provident Fund (NPF) plays a crucial role in household savings} and income support. NPF members, who number around 50,000, make monthly mandatory contributions of $12 \frac{1}{2}$ percent of wages ( $71 / 2$ percent paid by the employer, 5 percent by the employee). The NPF guarantees a minimal annual return on contributions of $2 \frac{1}{2}$ percent. Members are eligible to receive a lump-sum benefit at age 50, although members over age 40 can also retire, as long as they indicate that they do not intend to re-enter the labor force. Up to one-third of total contributions a year can be withdrawn if a worker of any age becomes redundant and cannot find a new job within 3 months. In addition, members can receive government-guaranteed loans for housing and furniture, and can use two-thirds of their total contributions as collateral for commercial bank loans (although the commercial banks note that they have discontinued such lending). Non-retirement withdrawals are common, and typically workers withdraw most of their savings prior to reaching the (low) retirement age.

\section{The NPF is also a key financial institution owing to its sizeable assets and} linkages with a wide range of public institutions and private households. It is the largest financial institution in the Solomon Islands, with total assets of SI\$376 million at end-June 2003 (two-thirds of total commercial bank assets). Member contributions account for the bulk of NPF liabilities and reached SI\$327 million as of mid-2003; the balance is mostly capital and reserves (SI\$45 million). The NPF's assets are concentrated heavily on government and quasi-government entities, including holdings of central government securities (SI\$94 million), loans to Malaita and Western province (SI\$18 million), and commercial loans to the electricity utility, Solomon Fishing, and the DBSI (collectively SI\$47 million). In 
regard to the private sector, the main NPF assets are housing loans to members (SI\$48 million), its share portfolio (SI\$66 million, mainly in Telekom and the NBSI), and its rental property (SI\$20 million). Demand and term deposits largely constitute the balance of its assets, much of which is held with the DBSI.

\section{The NPF's profitability and liquidity positions have come under increasing} stress (Table II.2). Earnings have steadily declined in line with the weak performance of interest and non-interest income, reflecting the poor loan performance, especially for housing lending to members and on term deposits held at the DBSI, and low income from equity investment and properties rented to the government. Although the return on member contributions has been kept low (contributions have had a positive real return in only two years since 1991), administration costs have been allowed to increase, and the net income

Table II.2. Solomon Islands: Financial Soundness Indicators of the NPF and the DBSI, 1998-2003

(In percent)

\begin{tabular}{|c|c|c|c|c|c|c|}
\hline & 1998 & 1999 & 2000 & 2001 & 2002 & 2003 \\
\hline \multicolumn{7}{|l|}{ National Provident Fund } \\
\hline \multicolumn{7}{|l|}{ Capital adequacy } \\
\hline Capital to average assets & 5.0 & 5.3 & 5.9 & 9.4 & 11.1 & 12.3 \\
\hline \multicolumn{7}{|l|}{ Earnings and profitability } \\
\hline Return on assets (net income to average total assets) & 7.0 & 7.8 & 6.0 & 4.8 & 3.4 & 2.8 \\
\hline Noninterest expenses to gross income & 35.9 & 32.9 & 40.8 & 42.7 & 56.7 & 64.0 \\
\hline Net operating income to gross income & 64.1 & 67.1 & 59.2 & 57.3 & 43.3 & 36.0 \\
\hline \multicolumn{7}{|l|}{ Liquidity } \\
\hline $\begin{array}{l}\text { Interest payout rate (interest appropriated to members } \\
\text { to net operating income) }\end{array}$ & 86.2 & 80.8 & 84.2 & 40.2 & 67.2 & 66.7 \\
\hline \multicolumn{7}{|l|}{ Development Bank of Solomon Islands } \\
\hline \multicolumn{7}{|l|}{ Capital adequacy } \\
\hline Capital to average assets & $\ldots$ & 5.6 & 4.8 & -11.4 & -32.1 & -38.4 \\
\hline \multicolumn{7}{|l|}{ Earnings and profitability } \\
\hline Return on assets (net income to average total assets) & $\ldots$ & -13.8 & -1.8 & -16.0 & -17.2 & -4.3 \\
\hline Noninterest expenses to gross income & 135.9 & 225.1 & 152.4 & 275.4 & 186.0 & 210.8 \\
\hline Net operating income to gross income & -33.5 & -114.6 & -14.8 & -175.4 & -261.7 & -110.8 \\
\hline \multicolumn{7}{|l|}{ Liquidity } \\
\hline Liquid assets to total assets & 6.3 & 1.3 & 0.8 & 1.2 & 1.2 & 2.6 \\
\hline
\end{tabular}


to total assets ratio has fallen from between 7 percent to 8 percent in 1998-99 to less than 3 percent in 2003. Liquidity levels at the NPF have also been under strain as a result of large government and private sector arrears on the contributions for their employees, and a surge in withdrawals in the wake of the government redundancy program in 2000. During the threeyear period mid-2000 to mid-2003, withdrawals amounted to SI\$170 million compared with contributions of just SI\$98 million. The NPF's liquidity position has recently improved somewhat following the payment since October 2003 of the government's current obligations, and the ending of the 3-year withdrawals associated with the 2000 redundancy program.

\section{Development Bank of Solomon Islands (DBSI)}

16. The state-owned DBSI has experienced severe liquidity and solvency difficulties. The DBSI was established in 1977 with the aim of promoting private sector-based economic development, and has assets represent about 7 percent of total commercial bank assets. The financial position of the DBSI has weakened for some time, and the DBSI has reported widening losses since 1997 and negative net assets since 2001 (SI\$23 million as of end-September 2003).

17. The DBSI's difficulties are in large part attributable to weak managerial and collection practices. Its loan portfolio, which accounts for the bulk of DBSI's assets, is severely impaired (SI\$58 million, of which SI\$22 million is reported as non-performing). Its lending operations have often been guided by noncommercial considerations based on a culture of loan rescheduling and perpetuation, poor credit assessment and management, and political interference. Lending has also been primarily focused on the agricultural sector where lending risks are especially high given the uncertainty over land ownership.

18. In the face of these difficulties, the DBSI has compounded its problems in its efforts to boost liquidity. In 1995, the DBSI began to accept deposits from the public, offering high interest rates in order to compete with the commercial banks, and borrowed heavily from the NPF. Since the average return on its assets has been around $3 \frac{1}{2}$ percent, the high rates offered on these deposits soon led to difficulties. As at end-2003, the DBSI's liabilities included borrowing obligations (SI\$29 million) and deposits (SI\$20 million), all of which are now in default. The DBSI's financial position also deteriorated markedly after the 1997 devaluation which triggered a surge in loan provisions, staff salaries, and foreign exchange losses on the European Investment Bank's (government-guaranteed) credit line. Subsequently, foreign credit line resources were discontinued.

19. The DBSI has attempted to cut costs to offset these negative developments, but these efforts have been insufficient. In 2002, the DBSI reduced working hours to six per day, retired several staff members, and closed four of its seven branches. The CBSI's on-site examination of DBSI largely confirmed that the DBSI has breached key prudential guidelines by a wide margin and has become illiquid and insolvent. The DBSI is slated for major restructuring or liquidation in the aftermath of the June 2004 Court decision that has transferred management of the DBSI to the CBSI. 


\section{Other Financial Institutions}

20. Following a rapid expansion in the 1990s, credit union activity has declined sharply in recent years. Of the 170 credit unions registered, only 18 are active, of which only three are in rural areas. Of the urban-based credit unions, their total assets amounted to SI\$30 million at end-2003. The standard interest rate on credit union loans is 12 percent. Members' deposits do not earn interest but are remunerated instead through distribution of profits in the form of dividends. By law, 10 percent of members' deposits must be held in bank deposits. The profitability of most urban credit unions has dropped and cash flow problems have emerged due to declining membership and the non-payment of contributions that are supposed to be deducted and transmitted directly by the government from members' salary.

21. The current business environment has left the insurance industry vulnerable. In 2003, there were five insurance companies, including two life insurance companies, and two insurance brokers, operating in the Solomon Islands. Total premiums received declined to SI\$16 million in the period 2000-02 from SI\$25 million in 1999.

22. The operations of the Home Finance Corporation (HFC) and the Small Business Finance Scheme (SBFC) have been considerably reduced. The HFC was established in 1990 to provide loans for low-to medium income housing. Funding was provided by the NPF, the Asian Development Bank, and from proceeds from the sale of HFC properties. The lack of funding since 1999 has brought HFC's lending to a standstill and attempts to privatize HFC in 2002 were unsuccessful. The SBFC was created in 1990 under the umbrella of the CBSI. It aims at facilitating access to bank credit for enterprises that are viable but lack required collateral. The CBSI vets loan applications, and provides an 80 percent guarantee on the unsecured portion of the approved loan and a rebate of 3 percentage points off the market interest rate. Lending under the SBFC scheme has been minimal; the outstanding portfolio at end-2003 was less than SI\$ million.

23. Finally, the operations of the Investment Corporation of Solomon Islands (ICSI) have been subdued in the aftermath of the 1999 civil conflict. The ICSI was established in 1988 to hold the government's shares in major public companies. The ICSI's main sources of income include bank term deposits and the government securities sold by the CBSI. While during 2003 several portfolio companies continued to experience severe financial difficulties (e.g., Solomon Islands Plantation Limited, Solomon Airlines, Solomon Islands Printers, and Sasape Marina), several other companies (e.g., Solomon Telekom, Kolombangara Forestry Plantation, and Soltai Fishing) improved their profitability. These improvements, however, fell short of improving the ICSI's financial position.

\section{B. Agenda for Financial Sector Reform}

24. A range of reform actions in the financial sector could assist in promoting private sector-based economic recovery in the medium term, focused in the following general areas. 
- The completion of the government debt restructuring discussion and repayment of arrears are preconditions for strengthening the financial system. The government debt default has weakened the balance sheet of all financial institutions and prevented the CBSI from undertaking liquidity management through open market operations. Furthermore, government arrears on rents and contributions for civil servants placed the NPF under financial distress. The partial settlement of these arrears in 2003 is a step in the right direction but needs to be sustained.

- Major bottlenecks affecting lending need to be alleviated. The high spreads levied by commercial banks, which reflect high lending risks, should narrow as the fiscal situation improves and lending demand recovers. A land reform program is required to broaden lending eligibility.

- The ownership status of the NBSI needs to be resolved. The current situation is not conducive to sound banking, especially given that the NBSI is the largest commercial bank and the only bank with a rural network.

- The NPF needs to strengthen its investment policies. The NPF has already taken steps in this direction, following recommendations of the 2003 on-site examination and ongoing technical assistance from the World Bank. Loan recovery has been stepped-up, and a comprehensive review of its investment policy is underway. Allowing the NPF to invest abroad could also be considered (Box II.3).

\section{Box II.3. Solomon Islands: Should The NPF Invest Abroad?}

Governments are typically reluctant to allow pension and provident funds to invest abroad due to concerns that this will increase the government's borrowing costs (by reducing demand for government securities), while jeopardizing the central bank's external reserve position. While these concerns are valid, there are several important offsetting considerations:

First, if there are significant inflows of foreign exchange, purchases of foreign assets by a provident fund can help reduce the need for open market operations to mop up excess liquidity. The current significant external budget support from Australia and other donors, and difficulties in conducting open market operations, suggests that this may be an opportune time to ease restrictions on foreign asset purchases by the NPF. Given the excess liquidity that presently exists in the banking sector, there is little risk that government financing costs will increase in the near-term if some savings are placed abroad.

Second, foreign asset purchases can yield significant diversification benefits, particularly for a small open economy like the Solomon Islands. These benefits accrue from allowing contributors to own a wide portfolio of foreign assets, the selection of which can be tailored so that asset price covariance with the economy's current prospects is negative. Moreover, since adverse economic shocks tend to weaken the currency, the local currency value of the pension funds assets increases when the economy stagnates.

However, allowing the NPF to acquire foreign assets would require vigilant supervision to ensure these funds are not lost in dubious investments. Much could be gained by restricting foreign asset purchases to broad equity index funds, and high grade corporate bonds and foreign government debt. 
- Finally, the recent Court decision to transfer the management of the DBSI to the CBSI paves the way for resolution of the future status of the DBSI. The CBSI is expected to enact a plan of action aimed at recovering overdue obligations and paying creditors and depositors, including through the sale of DBSI assets, and reducing wage and other operating costs. At the same time a sound strategy for development lending to farmers and small enterprises should be prepared, although this plan would not likely be executed through the DBSI. Micro financing through specialized institutions and financing of small projects by credit unions could be explored, utilizing donor assistance. 


\section{TAX SUMMARY ${ }^{1}$}

\section{A. Direct Taxes}

\section{Taxation of individuals}

Nature of tax: Residents are taxed on their worldwide income. Taxable income includes income from any business, employment, services rendered, rents, dividends, interest, pensions, and alimony. The values of housing and vehicle subsidies supplied by employers and education allowances paid by employers, are taxable. The tax year is the calendar year, although businesses may adopt an alternative accounting period. Tax returns are to be filed within three months of the balance date. Wages and salaries are taxed under the PAYE system.

Exemptions and deductions: Personal exemptions and deductions apply to residents only. When an individual is resident for only part of a year, the exemptions are subject to apportionment on a pro-rata basis. The basic exemption is SI\$,800 per taxpayer, with no distinction between single and married taxpayer. Otherwise deductions are: the cost not reimbursed by the employer for travel related to medical treatment of the taxpayer or of his/her family, the cost of overseas education not reimbursed by the employer for up to four single trips a child, life insurance premiums and contributions to superannuation funds to the extent that they exceed 5 percent but not more than 12.5 percent of the taxpayer's income, and alimony payments. Interest income of less than SI\$5,000 from savings deposits with any bank in the Solomon Islands is exempt. Residents qualify for double taxation relief when they are liable for overseas income tax.

$\begin{array}{lc}\underline{\text { Individuals }} & \underline{\text { Percent }} \\ \text { Up to } \$ 15,000 & 11 \\ \$ 15,001-\$ 30,000 & 23 \\ \$ 30,001-60,000 & 35 \\ \$ 60,001 \text { and up } & 40\end{array}$

\section{Taxation of Companies}

Nature of tax: Payable on resident company income accruing in, derived from, or receivable in the Solomon Islands or elsewhere. Companies incorporated in the Solomon Islands are residents. Nonresident companies pay tax on income accruing in, or derived from, the Solomon Islands. Under the provisional tax system, companies and businesses are required to make quarterly payments of taxes that will be payable for the current year. Such payments are credited against the tax for the year when the annual assessment is made.

\footnotetext{
${ }^{1}$ Prepared by Engin Dalgic (ext. 38771).
} 
Exemptions and deductions: The Commissioner of Inland Revenue, acting on the recommendation of the Foreign Investment Board, may grant any company (resident or nonresident) that commences a business in the Solomon Islands a tax holiday. The total income during the tax holiday is exempt from tax for periods of five years. Dividend contributions may also be exempt, subject to certain restrictions. In addition, The Minister of Finance may grant an income tax exemption to new business operations conducted by Solomon Islanders or Solomon Islands companies. The first SI\$25,000 of profits is exempt; this limit can be raised to a maximum of SI\$100,000 upon the Minister's discretion and Cabinet approval. The exemption can exceptionally be extended to 10 years with Cabinet approval. Profits of public enterprises and of any religious, charitable, benevolent, or educational institution are exempt.

Resident companies are required to deduct withholding tax from dividends paid to residents and nonresidents. The tax is final for nonresidents and for residents whose income (including dividend income) is less than SI\$10,000. When the income of a resident exceeds SI $\$ 10,000$, credit is given for the tax withheld on dividends. Losses may be carried forward for five years and be set off against future profits if majority shareholding remains unchanged. Bond issues are exempt until the amount capitalized is distributed. Business license fees paid to provinces are treated as prepayments of income tax. Accelerated depreciation is provided for capital expenditure in timber and mining operations, while certain expenditures on agricultural development, including for coconuts, palm oil, and cocoa, can be written off in full in the year they are incurred.

Rates (in percent):

Companies incorporated in the Solomon Islands $\quad 30$

Other companies

Withholding taxes (in percent):

Residents:

Income from contracting

Royalties

Fishing operations

Lease of property

Sale of marine products

Stevedoring services

Nonresidents:

Interest

Royalties

Income from contracting

Income from ships and aircraft

Insurance premiums

Film rental

Remuneration to pole and line or long-line fishermen Lease income 
Dividends

Dividend Taxes (in percent):

Residents

Nonresidents

\section{Social security contributions}

Nature of tax: Compulsory social security scheme for all public and private employees. A total of 7.5 percent of earnings is paid by the employer, and 5 percent by the employee.

\section{Capital Gains tax}

None, except for business assets.

\section{Estate, gift, and death duties}

None

\section{B. Indirect Taxes}

\section{Excise duties}

Nature of tax: An excise duty is levied on plugs, twist, fig, stick, cake, and coarse cut tobacco, and on beer and cigarettes.
Beer
SI\$4.00 per litre
Tobacco
SI $\$ 40.00$ per $\mathrm{kg}$.
Cigarettes
SI\$0.30 per stick or SI\$360.00 per kg.

\section{Goods taxes}

Nature of tax: Imposed and levied on the final wholesale price of goods that are produced domestically or imported, whether new or used. Manufacturers and wholesale merchants are required to register with the Inland Revenue and are obliged to calculate the tax payable, charge and collect the tax from customers, and pay the tax to the Inland Revenue Division each month.

\section{Exemptions and deductions:}

- $\quad$ Drugs and medicine, and surgical tools

- $\quad$ Educational, scientific and religious goods, works of art and antiques

- $\quad$ Goods for use by governments, representatives of governments, and public bodies 
- $\quad$ Goods manufactured and sold by small businesses

- Miscellaneous: contraceptives, goods designed for use by disabled people, secondhand goods, goods purchased for export, coffins, bird food, aquatic and marine food, coins, goods used as aids to manufacture, safety equipment, aircraft, buses, flags, awards, fire equipment.

Rates (in percent):

Imported goods

Locally manufactured goods

Rice

\section{Services taxes}

Nature of tax: A sales tax is levied at the retail level for specified services.

Rates (in percent, unless otherwise noted):

Local and overseas telecommunications $\quad 10$

Restaurant services 10

Tickets for overseas travel $\quad$ SI\$10

Tickets for domestic air travel SI\$10

Tickets for domestic sea travel 10

Hire of video $\quad$ SI\$2 per tape

Movie tickets $\quad$ SI\$0.50 per ticket

Accounting, legal, and security services 10

Motor vehicle rental 10

Real estate agency services $\quad 10$

Professional services $\quad 10$

Petroleum and diesel SI\$0.1 per liter

Video equipment hire $\quad 10$

Computer equipment hire $\quad 10$

Hire of vessel and aircraft 10

Hire of plant machinery and equipment 10

Electricity repairs and equipment 10

Barber and beauty saloon services $\quad 10$

Casinos

SI\$5 per entrance

Laundry services 10

$\begin{array}{ll}\text { Tire services } & 10\end{array}$

\section{Import taxes}

Nature of tax: Levied at an ad valorem rate on the c.i.f. value of imports, although specific rates apply on alcoholic beverages, tobacco products, and fuel. 
Exemptions and deductions: The following imports are exempt:

- $\quad$ Nonconsumable goods for all levels of government.

- Goods imported under diplomatic and similar privileges, or under memoranda of understanding with foreign governments and international organizations.

- $\quad$ Aircraft parts and equipment, aircraft fuel, and lubricants for use in foreign aircraft.

- $\quad$ Containers, coverings, packages, etc.

- $\quad$ Cultural and educational articles; health goods for relief work and charity; fire fighting equipment; goods for volunteer organizations; marine and port equipment; fuel and life-saving equipment; religious goods; scientific and meteorological equipment; goods for telecommunications systems.

- $\quad$ Fishing gear and equipment.

- $\quad$ Most capital goods and agricultural equipment.

- $\quad$ Goods for tourism or imported under investment incentives.

- $\quad$ Goods imported by armed forces, demolition explosives and machinery, clothes and accessories required for civil servants.

- Medals and decorations; uniforms and insignias of youth organizations; advertising samples; portraits, films, recordings for personal use.

Rates (in percent):

Foodstuff

Minerals, fuels

Chemicals

Machinery and transport equipment

Domestic products

Beer

Cigarettes
$0-20$

$0-20$, plus specific rates

$5-15$

$5-20$

$0-20$

SI 10 per litre

SI $\$ 0.42$ per stick or SI $\$ 500$ per $\mathrm{kg}$.

\section{Export Taxes}

Nature of tax: Levied on various land and marine fauna shells, gold, metal scrap, logs and lumber, fish, and various agricultural products. The valuation base is the f.o.b. price or value of the export, except in the case of timber and some fish where the value for duty is a "determined value" adjustable from time to time.

Exemptions and deductions: Spices, coconut, palm oil, canned fish, rice, some shells, copra, biscuits, beer, manufactured tobacco. Exemptions for export taxes on logs are granted on a case-by-case basis. 
Rates (in percent, unless otherwise noted):

Shells

Gold

Metal scrap-nonferrous

SI\$1.5/metric ton

Metal scrap

15

Timber logs:

If valued up to SI $\$ 550 / \mathrm{m}^{3}$

25 percent (of the determined value)

If valued between SIS $550-850 / \mathrm{m}^{3}$

SI $\$ 137.50$ plus 40 percent of difference

If valued more than SI $\$ 850 / \mathrm{m}^{3}$

Fresh, chilled, or frozen fish (some) SI\$257.50 plus 60 percent of difference

Dried, salted, smoked or cooked fish 5

Various other agricultural, forest, marine products

\section{Other Taxes and Charges}

\section{Business licenses}

Nature of tax: Annual levy payable by retail traders at various rates.

\section{Other licenses}

Nature of tax: Licenses on motor vehicles, driving permits, fishing vessels, work permits, and firearms.

Motor vehicles: specific rates according to engine displacement and weight varying from SI\$150 to SI\$2,500.

Driving license: SI\$75

Dealer license: SI $\$ 10,000$

Work permits application: SI\$200, and upon approval SI\$500 for two years.

\section{Stamp duties}

Nature of tax: Levied on agreements, insurance policies, bills of sales and exchange, promissory notes, and various property and title transfers. Some ad valorem, some specific.

Exemptions and deductions: Bills of exchange by any bank for government purposes.

The duty varies from SI\$2 on any instrument, and between $0.15-3.75$ percent depending on the value of property. 
Table 1. Solomon Islands: Summary of Real Sector Indicators, 1997-2003

\begin{tabular}{|c|c|c|c|c|c|c|c|}
\hline & 1997 & 1998 & 1999 & 2000 & 2001 & 2002 & $\begin{array}{r}\text { Est. } \\
2003\end{array}$ \\
\hline \multicolumn{8}{|l|}{ Real GDP 1/ } \\
\hline \multirow[t]{2}{*}{ Percentage growth } & -1.4 & 1.8 & -0.5 & -14.3 & -9.0 & -1.6 & 5.1 \\
\hline & \multicolumn{7}{|c|}{ (Contribution to growth; in percent) } \\
\hline Primary & 0.3 & -1.0 & -0.7 & -6.0 & -1.3 & 0.8 & 5.8 \\
\hline Agriculture & 0.4 & -0.2 & -1.0 & -0.7 & -0.5 & 0.3 & 1.2 \\
\hline Forestry & -0.4 & -1.9 & 0.6 & -0.7 & 0.0 & 0.2 & 1.7 \\
\hline Fishing & 0.3 & 1.1 & -0.3 & -4.7 & -0.8 & 0.3 & 2.9 \\
\hline Secondary $2 /$ & -0.9 & -1.0 & -0.6 & -1.2 & -1.0 & 0.2 & 0.4 \\
\hline Tertiary $3 /$ & -0.8 & 1.2 & -0.9 & -2.4 & -2.3 & -2.4 & -1.0 \\
\hline Nonmonetary sector & 0.2 & -0.2 & 0.8 & 0.5 & 0.7 & 0.7 & -0.1 \\
\hline \multirow[t]{2}{*}{ Indirect taxes and subsidies } & -0.2 & 2.8 & 0.9 & -5.0 & -5.1 & -0.8 & $\ldots$ \\
\hline & \multicolumn{7}{|c|}{ (In 1,000 metric tons, unless otherwise specified) } \\
\hline \multicolumn{8}{|l|}{ Production of major commodities } \\
\hline Timber $(1,000$ cubic meters $)$ & 650.0 & 604.0 & 622.0 & 536.0 & 534.0 & 550.0 & 714.1 \\
\hline Fish & 40.7 & 49.4 & 48.0 & 21.2 & 17.7 & 18.5 & 29.0 \\
\hline Copra & 28.7 & 27.0 & 23.2 & 19.0 & 1.7 & 1.7 & 14.8 \\
\hline Cocoa & 3.9 & 3.5 & 2.4 & 2.3 & 2.0 & 2.9 & 4.6 \\
\hline \multirow[t]{2}{*}{ Palm oil } & 28.9 & 29.1 & 12.9 & $\ldots$ & $\ldots$ & $\ldots$ & $\ldots$ \\
\hline & \multicolumn{7}{|c|}{ (Annual percentage change) } \\
\hline Consumer prices (average) & 8.1 & 12.3 & 8.0 & 6.9 & 7.6 & 9.4 & 10.1 \\
\hline Consumer prices (end-of-period) & 10.3 & 10.3 & 7.3 & 7.6 & 6.5 & 15.4 & 3.8 \\
\hline
\end{tabular}

Sources: Data provided by the Solomon Islands authorities; and Fund staff estimates.

1/ Estimates at 1992 factor cost.

2/ Includes mining and exploration, manufacturing, electricity and water, and construction.

3 / Includes retail and wholesale trade, transportation and communications, finance, and other services. 
Table 2. Solomon Islands: Real GDP by Sectoral Origin, 1997-2003

(In millions of Solomon Islands dollars; estimates at 1992 prices)

\begin{tabular}{|c|c|c|c|c|c|c|c|}
\hline & 1997 & 1998 & 1999 & 2000 & 2001 & 2002 & $\begin{array}{r}\text { Est. } \\
2003\end{array}$ \\
\hline Primary sector & 151.1 & 143.2 & 137.4 & 90.6 & 81.6 & 88.9 & 123.5 \\
\hline Agriculture & 36.8 & 35.4 & 27.6 & 22.2 & 18.9 & 20.6 & 27.6 \\
\hline Forestry & 47.7 & 32.9 & 37.3 & 32.2 & 32.0 & 34.1 & 44.2 \\
\hline Fishing & 66.5 & 74.9 & 72.5 & 36.2 & 30.7 & 34.1 & 51.7 \\
\hline Secondary sector & 61.1 & 53.2 & 48.4 & 39.1 & 32.3 & 33.0 & 35.1 \\
\hline Mining and exploration & 0.5 & -1.7 & -4.8 & -2.3 & 0.1 & 0.1 & 0.0 \\
\hline Manufacturing & 28.5 & 29.4 & 29.4 & 23.6 & 18.9 & 17.9 & 16.1 \\
\hline Electricity and water & 15.4 & 16.3 & 17.1 & 14.3 & 11.3 & 13.3 & 15.8 \\
\hline Construction & 16.7 & 9.2 & 6.6 & 3.5 & 1.9 & 1.7 & 3.2 \\
\hline Tertiary & 280.8 & 290.3 & 283.6 & 264.8 & 249.6 & 234.7 & 228.7 \\
\hline Retail and wholesale trade & 73.7 & 80.3 & 75.2 & 67.6 & 60.2 & 66.1 & 68.1 \\
\hline Transportation and communications & 30.8 & 34.6 & 36.4 & 29.1 & 23.3 & 26.3 & 11.8 \\
\hline Finance & 36.5 & 31.6 & 32.1 & 31.0 & 30.0 & 29.6 & 29.1 \\
\hline Other services & 139.9 & 143.8 & 139.9 & 137.1 & 136.2 & 112.7 & 119.7 \\
\hline Monetary GDP at factor cost & 493.0 & 486.7 & 469.4 & 394.5 & 363.5 & 356.6 & 387.3 \\
\hline Nonmonetary GDP at factor cost & 199.3 & 197.8 & 203.7 & 207.3 & 211.7 & 216.1 & 215.8 \\
\hline Food & 157.2 & 160.3 & 165.6 & 170.0 & 175.1 & 179.8 & 179.9 \\
\hline Construction & 4.3 & 4.4 & 4.5 & 4.7 & 4.9 & 5.0 & 5.0 \\
\hline Real GDP at factor cost & 692.2 & 685.5 & 673.1 & 601.8 & 575.3 & 572.7 & 603.1 \\
\hline \multicolumn{8}{|l|}{ Memorandum item: } \\
\hline Nominal GDP at current market prices & 1,452 & 1,561 & 1,605 & 1,523 & 1,447 & 1,605 & 1,772 \\
\hline
\end{tabular}

Sources: Data provided by the Solomon Islands authorities; and Fund staff estimates. 
Table 3. Solomon Islands: Real GDP Growth Rates by Sectoral Origin, 1997-2003 (Annual percentage change)

\begin{tabular}{lrrrrrrr}
\hline & & & & & & & \\
& 1997 & 1998 & 1999 & 2000 & 2001 & 2002 & 2003 \\
& & & & & & & \\
& & & & & & & \\
& & & & & & & \\
& 1.5 & -5.2 & -4.0 & -34.1 & -10.0 & 5.8 & 12.9 \\
Primary sector & 10.3 & -3.8 & -22.0 & -19.8 & -14.6 & 9.0 & 33.6 \\
$\quad$ Agriculture & -6.7 & -31.1 & 13.4 & -13.6 & -0.8 & 6.7 & 29.5 \\
Forestry & 3.5 & 12.7 & -3.2 & -50.1 & -15.2 & 11.2 & 51.7 \\
Fishing & & & & & & & \\
& -10.6 & -13.0 & -9.4 & -18.8 & -17.3 & 4.0 & -5.2 \\
Secondary sector & 65.7 & -62.1 & 180.7 & -51.4 & $\ldots$ & $\ldots$ & $\ldots$ \\
Mining and exploration & 1.1 & 3.3 & 0.1 & -19.8 & -19.8 & -5.2 & -10.3 \\
Manufacturing & 7.4 & 5.5 & 4.9 & -16.4 & -20.6 & 16.9 & 19.4 \\
Electricity and water & -34.6 & -45.2 & -27.7 & -46.6 & -45.6 & -12.4 & 88.0 \\
Construction & & & & & & & \\
& -2.2 & 9.0 & -6.3 & -10.2 & -10.9 & 9.7 & 3.0 \\
Tertiary & -0.2 & 9.0 & -6.3 & -10.2 & -10.9 & 9.7 & 3.0 \\
Retail and wholesale trade & -5.4 & 12.3 & 5.0 & -20.0 & -20.0 & 13.9 & 5.7 \\
Transportation and communications & -7.1 & -13.4 & 1.5 & -3.3 & -3.3 & -1.3 & -1.7 \\
Finance & 0.3 & 6.4 & -3.5 & -1.8 & -0.2 & -20.1 & -12.4 \\
Other services & & & & & & & \\
& -2.3 & -1.3 & -3.6 & -16.0 & -7.9 & -1.9 & 8.6 \\
Monetary GDP at factor cost & & & & & & & \\
& 0.8 & -0.2 & 2.4 & 1.8 & 2.2 & 2.1 & -0.2 \\
Nonmonetary GDP at factor cost & 2.7 & 2.6 & 2.6 & 2.6 & 3.1 & 2.6 & 0.1 \\
Food & 1.9 & 2.0 & 1.9 & 4.0 & 4.0 & 2.0 & 0.1 \\
Construction & & & & & & & \\
Real GDP at market prices & -1.4 & 1.8 & -0.5 & -14.3 & -9.0 & -1.6 & 5.1 \\
& & & & & & & \\
\hline & & & & & & &
\end{tabular}

Sources: Data provided by the Solomon Islands authorities; and Fund staff estimates. 
Table 4. Solomon Islands: Honiara Retail Price Index, 1997-2003

$$
(1990=100)
$$

\begin{tabular}{|c|c|c|c|c|c|c|c|c|c|}
\hline Weight & $\begin{array}{c}\text { Food } \\
468\end{array}$ & $\begin{array}{c}\text { Drink } \\
\text { and } \\
\text { Tobacco } \\
50\end{array}$ & $\begin{array}{l}\text { Clothing } \\
\text { and } \\
\text { Footwear } \\
57\end{array}$ & $\begin{array}{c}\text { Transport } \\
110\end{array}$ & $\begin{array}{c}\text { Housing } \\
\text { and } \\
\text { Utilities } \\
109\end{array}$ & $\begin{array}{c}\text { Miscel- } \\
\text { laneous } \\
99\end{array}$ & $\begin{array}{c}\text { Local } \\
\text { Items } \\
79\end{array}$ & $\begin{array}{l}\text { Imported } \\
\text { Items } \\
28\end{array}$ & $\begin{array}{c}\text { All } \\
\text { Items } \\
1,000\end{array}$ \\
\hline 1997 & 160.5 & 173.6 & 127.4 & 170.0 & 144.4 & 157.3 & 182.0 & 147.7 & 159.6 \\
\hline 1998 & 181.6 & 189.7 & 135.6 & 175.5 & 170.1 & 195.0 & 194.3 & 165.7 & 179.3 \\
\hline 1999 & 201.8 & 186.7 & 136.5 & 190.6 & 182.3 & 207.6 & 201.1 & 173.6 & 193.7 \\
\hline 2000 & 215.1 & 231.1 & 137.4 & 207.9 & 199.1 & 213.1 & 211.9 & 176.3 & 207.4 \\
\hline 2001 & 235.3 & 240.4 & 136.9 & 224.0 & 197.3 & 220.3 & 237.5 & 178.1 & 223.3 \\
\hline 2002 & 260.4 & 282.3 & 138.3 & 247.8 & 206.6 & 254.5 & 256.6 & 181.7 & 244.2 \\
\hline 2003 & 271.0 & 314.1 & 139.3 & 310.5 & 242.7 & 288.8 & 294.5 & 198.7 & 268.5 \\
\hline \multicolumn{10}{|l|}{2000} \\
\hline January & 202.1 & 226.7 & 137.7 & 193.0 & 193.7 & 211.4 & 205.3 & 174.7 & 198.1 \\
\hline February & 202.8 & 232.8 & 137.9 & 196.3 & 197.7 & 210.9 & 204.5 & 176.2 & 199.5 \\
\hline March & 202.4 & 208.2 & 138.0 & 196.3 & 196.2 & 211.3 & 204.4 & 175.9 & 198.0 \\
\hline April & 210.5 & 203.6 & 137.8 & 197.9 & 196.7 & 212.2 & 209.4 & 176.0 & 202.2 \\
\hline May & 212.3 & 207.9 & 137.8 & 197.9 & 197.0 & 212.2 & 209.6 & 176.3 & 203.4 \\
\hline June & 212.8 & 207.9 & 137.8 & 197.9 & 197.1 & 212.2 & 209.6 & 176.5 & 203.6 \\
\hline July & 224.0 & 262.4 & 137.8 & 211.8 & 200.3 & 214.3 & 214.5 & 176.6 & 214.0 \\
\hline August & 224.1 & 262.4 & 137.3 & 219.4 & 201.2 & 214.6 & 214.5 & 176.6 & 215.0 \\
\hline September & 222.7 & 261.2 & 137.0 & 219.7 & 201.2 & 214.5 & 217.7 & 176.8 & 214.6 \\
\hline October & 223.3 & 232.4 & 137.0 & 219.7 & 202.5 & 214.5 & 217.7 & 176.8 & 213.6 \\
\hline November & 222.2 & 233.6 & 136.4 & 221.9 & 202.5 & 214.5 & 217.9 & 176.8 & 213.3 \\
\hline December & 221.7 & 233.6 & 136.6 & 222.3 & 203.3 & 214.6 & 217.9 & 176.8 & 213.3 \\
\hline \multicolumn{10}{|l|}{2001} \\
\hline January & 228.1 & 233.3 & 136.7 & 225.9 & 196.4 & 220.6 & 235.8 & 177.2 & 219.5 \\
\hline February & 229.3 & 233.4 & 136.7 & 225.9 & 196.4 & 220.6 & 235.7 & 178.8 & 220.1 \\
\hline March & 230.6 & 233.4 & 136.7 & 225.9 & 196.8 & 220.6 & 236.4 & 180.4 & 220.9 \\
\hline April & 236.5 & 229.7 & 136.7 & 225.8 & 200.5 & 220.6 & 237.0 & 180.1 & 223.9 \\
\hline May & 235.5 & 245.7 & 136.7 & 224.7 & 198.7 & 220.6 & 237.0 & 180.0 & 224.1 \\
\hline June & 232.0 & 232.2 & 136.7 & 225.9 & 201.1 & 222.0 & 237.1 & 180.0 & 222.2 \\
\hline July & 237.6 & 245.3 & 136.7 & 225.9 & 193.3 & 220.4 & 237.5 & 180.0 & 224.5 \\
\hline August & 235.2 & 232.3 & 136.7 & 225.9 & 196.6 & 218.0 & 237.8 & 180.0 & 222.8 \\
\hline September & 238.0 & 230.9 & 137.2 & 220.6 & 197.1 & 220.9 & 238.9 & 175.4 & 223.7 \\
\hline October & 238.8 & 250.3 & 137.2 & 220.6 & 197.1 & 220.0 & 238.9 & 175.1 & 225.0 \\
\hline November & 240.7 & 255.5 & 137.3 & 220.6 & 197.1 & 218.6 & 238.9 & 175.1 & 226.1 \\
\hline December & 241.7 & 262.9 & 137.3 & 220.6 & 197.1 & 220.4 & 238.9 & 175.1 & 227.1 \\
\hline
\end{tabular}


Table 4. Solomon Islands: Honiara Retail Price Index, 1997-2003 (continued)

$$
(1990=100)
$$

\begin{tabular}{|c|c|c|c|c|c|c|c|c|c|}
\hline Weight & $\begin{array}{c}\text { Food } \\
468\end{array}$ & $\begin{array}{c}\text { Drink } \\
\text { and } \\
\text { Tobacco } \\
50\end{array}$ & $\begin{array}{c}\text { Clothing } \\
\text { and } \\
\text { Footwear } \\
57\end{array}$ & $\begin{array}{c}\text { Transport } \\
110\end{array}$ & $\begin{array}{c}\text { Housing } \\
\text { and } \\
\text { Utilities } \\
109\end{array}$ & $\begin{array}{l}\text { Miscel- } \\
\text { laneous } \\
99\end{array}$ & $\begin{array}{l}\text { Local } \\
\text { Items } \\
79\end{array}$ & $\begin{array}{l}\text { Imported } \\
\text { Items } \\
28\end{array}$ & $\begin{array}{c}\text { All } \\
\text { Items } \\
1,000\end{array}$ \\
\hline \multicolumn{10}{|l|}{2002} \\
\hline January & 242.6 & 267.4 & 137.3 & 220.8 & 202.8 & 227.7 & 250.2 & 176.5 & 228.4 \\
\hline February & 247.0 & 267.8 & 137.6 & 220.8 & 202.5 & 227.7 & 250.5 & 176.5 & 230.5 \\
\hline March & 250.0 & 268.3 & 137.6 & 220.8 & 202.9 & 227.7 & 250.5 & 176.9 & 232.0 \\
\hline April & 248.3 & 270.0 & 137.6 & 231.5 & 203.7 & 230.0 & 250.5 & 178.5 & 232.7 \\
\hline May & 251.1 & 274.0 & 137.6 & 231.5 & 204.1 & 232.8 & 250.7 & 178.9 & 234.6 \\
\hline June & 258.9 & 259.9 & 139.5 & 234.1 & 204.5 & 268.4 & 251.4 & 178.4 & 241.6 \\
\hline July & 262.7 & 274.9 & 139.5 & 234.1 & 205.0 & 268.4 & 254.4 & 179.8 & 244.4 \\
\hline August & 267.0 & 283.6 & 139.5 & 234.1 & 206.6 & 268.4 & 255.7 & 182.5 & 247.2 \\
\hline September & 271.7 & 298.7 & 138.5 & 279.3 & 210.3 & 267.1 & 264.9 & 186.6 & 256.2 \\
\hline October & 274.3 & 303.8 & 138.5 & 285.0 & 211.7 & 276.6 & 266.6 & 188.3 & 259.6 \\
\hline November & 275.1 & 307.8 & 138.5 & 290.0 & 212.5 & 279.3 & 267.1 & 188.7 & 261.1 \\
\hline December & 275.5 & 311.7 & 138.5 & 291.4 & 212.9 & 280.3 & 266.4 & 189.3 & 261.8 \\
\hline \multicolumn{10}{|l|}{2003} \\
\hline January & 274.8 & 312.3 & 138.5 & 295.4 & 212.3 & 281.2 & 290.4 & 190.6 & 263.9 \\
\hline February & 269.3 & 312.8 & 138.6 & 299.7 & 213.6 & 283.8 & 290.4 & 192.1 & 262.2 \\
\hline March & 270.5 & 299.1 & 138.6 & 299.7 & 223.6 & 283.8 & 290.5 & 193.7 & 263.3 \\
\hline April & 269.5 & 304.7 & 139.5 & 323.9 & 249.5 & 290.0 & 292.3 & 196.4 & 269.4 \\
\hline May & 272.6 & 301.5 & 139.5 & 320.9 & 250.1 & 288.9 & 293.8 & 198.1 & 270.5 \\
\hline June & 268.5 & 306.4 & 139.5 & 315.0 & 250.8 & 288.6 & 294.1 & 200.8 & 268.4 \\
\hline July & 268.0 & 307.4 & 139.5 & 315.2 & 251.9 & 288.4 & 297.8 & 201.9 & 268.6 \\
\hline August & 271.2 & 311.3 & 139.5 & 318.9 & 252.0 & 290.3 & 296.9 & 201.7 & 270.8 \\
\hline September & 270.5 & 311.3 & 139.5 & 317.3 & 252.0 & 291.4 & 296.9 & 201.7 & 270.4 \\
\hline October & 272.7 & 332.0 & 139.5 & 306.8 & 252.2 & 292.4 & 297.0 & 201.9 & 271.4 \\
\hline November & 272.5 & 334.5 & 139.5 & 306.8 & 252.4 & 292.4 & 297.6 & 202.7 & 271.6 \\
\hline December & 271.9 & 336.4 & 139.5 & 306.8 & 252.4 & 294.2 & 296.8 & 202.7 & 271.5 \\
\hline \multicolumn{10}{|l|}{2004} \\
\hline January & 282.3 & 341.2 & 139.5 & 308.2 & 252.3 & 294.4 & 306.2 & 202.8 & 277.6 \\
\hline February & 290.3 & 345.1 & 139.7 & 310.6 & 254.6 & 302.0 & 307.2 & 204.3 & 282.9 \\
\hline March & 289.5 & 345.4 & 139.7 & 310.1 & 256.2 & 304.3 & 309.7 & 203.4 & 283.0 \\
\hline
\end{tabular}

Sources: National Statistical Office; and Central Bank of Solomon Islands. 
Table 5. Solomon Islands: Formal Employment, 1997-2003

(Number of employees)

\begin{tabular}{|c|c|c|c|c|c|c|c|}
\hline & 1997 & 1998 & 1999 & 2000 & 2001 & 2002 & $\begin{array}{r}\text { Est. } \\
2003\end{array}$ \\
\hline Total & 33,349 & 34,061 & 31,061 & 28,286 & 28,826 & 27,876 & 28,376 \\
\hline \multicolumn{8}{|l|}{ Classification by industry } \\
\hline Agriculture & 3,393 & 3,356 & $\ldots$ & $\ldots$ & $\ldots$ & $\ldots$ & $\ldots$ \\
\hline Forestry & 3,001 & 2,658 & $\ldots$ & $\ldots$ & $\ldots$ & $\ldots$ & $\ldots$ \\
\hline Fishing & 1,677 & 1,412 & $\ldots$ & $\ldots$ & $\ldots$ & $\ldots$ & $\ldots$ \\
\hline Manufacturing 1/ & 4,098 & 4,348 & $\ldots$ & $\ldots$ & $\ldots$ & $\ldots$ & $\ldots$ \\
\hline Electricity and water & 329 & 387 & $\ldots$ & $\ldots$ & $\ldots$ & $\ldots$ & $\ldots$ \\
\hline Construction & 1,367 & 1,187 & $\ldots$ & $\ldots$ & $\ldots$ & $\ldots$ & $\ldots$ \\
\hline Trading 2/ & 4,210 & 4,641 & $\ldots$ & $\ldots$ & $\ldots$ & $\ldots$ & $\ldots$ \\
\hline Transportation and communications & 1,672 & 1,878 & $\ldots$ & $\ldots$ & $\ldots$ & $\ldots$ & $\ldots$ \\
\hline Finance & 1,392 & 1,183 & $\ldots$ & $\ldots$ & $\ldots$ & $\ldots$ & $\ldots$ \\
\hline Administration & 3,937 & 4,261 & $\ldots$ & $\ldots$ & $\ldots$ & $\ldots$ & $\ldots$ \\
\hline Other services & 8,273 & 8,750 & $\ldots$ & $\cdots$ & $\cdots$ & $\cdots$ & $\cdots$ \\
\hline \multicolumn{8}{|l|}{ Classification by public/private sector } \\
\hline Total public sector & 10,105 & 10,348 & $\ldots$ & $\ldots$ & $\ldots$ & $\ldots$ & $\ldots$ \\
\hline Central government & 8,500 & 8,176 & $\ldots$ & $\ldots$ & $\ldots$ & $\ldots$ & $\ldots$ \\
\hline Provincial governments & 826 & 1,321 & $\ldots$ & $\ldots$ & $\ldots$ & $\ldots$ & $\ldots$ \\
\hline Statutory authorities & 779 & 851 & $\ldots$ & $\ldots$ & $\ldots$ & $\ldots$ & $\ldots$ \\
\hline Total private sector & 23,244 & 23,713 & $\ldots$ & $\ldots$ & $\ldots$ & $\ldots$ & $\ldots$ \\
\hline
\end{tabular}

Sources: National Statistical Office; and Central Bank of Solomon Islands.

1/ Manufacturing includes mining.

2/ Trading includes retail, wholesale, restaurants, and hotels. 
Table 6. Solomon Islands: Summary of Central Government Budget, 1997-2003

\begin{tabular}{|c|c|c|c|c|c|c|c|}
\hline & 1997 & 1998 & 1999 & 2000 & 2001 & 2002 & $\begin{array}{r}\text { Est. } \\
2003\end{array}$ \\
\hline Total revenue and grants & 28.9 & 29.0 & 27.0 & 22.1 & 23.5 & 18.7 & 39.8 \\
\hline Total revenue & 22.2 & 21.9 & 24.4 & 18.3 & 15.3 & 16.1 & 21.5 \\
\hline Tax revenue & 19.2 & 19.7 & 22.1 & 16.9 & 14.0 & 15.4 & 19.6 \\
\hline Income and profits & 6.7 & 8.3 & 8.7 & 6.3 & 5.1 & 4.8 & 5.3 \\
\hline Goods and services & 3.2 & 3.7 & 5.1 & 4.4 & 4.4 & 4.6 & 6.6 \\
\hline International trade & 9.3 & 7.7 & 8.3 & 6.1 & 4.5 & 6.1 & 7.7 \\
\hline Other revenue & 3.0 & 2.1 & 2.3 & 1.5 & 1.3 & 0.7 & 1.8 \\
\hline Stamp duty & 0.3 & 0.2 & 0.2 & 0.1 & 0.1 & 0.2 & 0.2 \\
\hline Licenses and fees & 0.2 & 0.2 & 0.2 & 0.1 & 0.1 & 0.2 & 0.2 \\
\hline Miscellaneous revenue & 2.6 & 1.7 & 1.9 & 1.3 & 1.0 & 0.3 & 1.4 \\
\hline Grants & 6.7 & 7.1 & 2.6 & 3.7 & 8.2 & 2.6 & 18.3 \\
\hline Development grants & 6.7 & 18.5 & 17.1 & 14.4 & 8.0 & 2.2 & 14.4 \\
\hline Recurrent budget grants & 0.0 & 2.3 & 0.3 & 0.7 & 0.3 & 0.5 & 3.9 \\
\hline Expenditure 1/ & 33.2 & 28.2 & 30.3 & 29.7 & 36.1 & 29.7 & 39.6 \\
\hline Recurrent expenditure & 25.7 & 21.0 & 26.0 & 25.1 & 27.2 & 26.5 & 23.8 \\
\hline Compensation of employees & 11.2 & 10.2 & 11.2 & 13.3 & 13.1 & 11.7 & 9.7 \\
\hline Goods and services & 7.6 & 4.7 & 5.0 & 4.7 & 5.0 & 4.5 & 5.2 \\
\hline Interest & 3.4 & 1.7 & 4.2 & 3.5 & 1.3 & 3.4 & 2.9 \\
\hline Grants to provinces and others & 2.9 & 3.8 & 4.5 & 2.8 & 2.3 & 0.9 & 2.2 \\
\hline Employer social benefits & 0.2 & 0.2 & 0.6 & 0.3 & 0.0 & 0.2 & 0.2 \\
\hline Compensation payments and other & 0.5 & 0.4 & 0.4 & 0.5 & 5.4 & 5.8 & 3.6 \\
\hline Development expenditure & 7.5 & 7.2 & 4.3 & 4.6 & 8.9 & 3.2 & 15.7 \\
\hline Current balance & -3.5 & 3.2 & -1.3 & -6.1 & -11.7 & -9.9 & 1.5 \\
\hline Overall balance (above-the-line) & -4.3 & 0.8 & -3.3 & -7.6 & -12.6 & -10.9 & 0.2 \\
\hline Discrepancy 2/ & -0.7 & -1.1 & -0.4 & 2.6 & 0.7 & 1.4 & -1.6 \\
\hline Overall balance (below-the-line) & -4.9 & -0.3 & -3.7 & -4.9 & -11.9 & -9.6 & -1.4 \\
\hline Financing & 4.9 & 0.3 & 3.7 & 4.9 & 11.9 & 9.6 & 1.4 \\
\hline Foreign (net) & -0.3 & 4.9 & 1.9 & 0.6 & 5.0 & 3.8 & 0.4 \\
\hline Disbursements & 0.7 & 5.9 & 2.9 & 1.5 & 6.1 & 5.4 & 1.4 \\
\hline Amortization 1/ & -1.0 & -1.0 & -1.0 & -0.9 & -1.1 & -1.6 & -1.6 \\
\hline Debt forgiveness & 0.0 & 0.0 & 0.0 & 0.0 & 0.0 & 0.0 & 0.7 \\
\hline Domestic bank and nonbank (net) & 0.2 & -1.4 & -0.1 & 4.2 & -1.4 & -2.9 & -6.6 \\
\hline Banking system 1/ & 0.2 & -3.0 & -0.1 & 5.2 & -3.3 & -1.0 & -6.6 \\
\hline Central bank & 0.0 & -3.4 & -0.4 & 4.3 & 2.9 & 2.4 & -3.9 \\
\hline Commercial banks & 0.1 & 0.4 & 0.4 & 1.0 & -6.2 & -3.5 & -2.7 \\
\hline Nonbank 1/ & 0.0 & 1.6 & 0.0 & -1.1 & 1.9 & -1.9 & 0.0 \\
\hline National Provident Fund & 0.1 & 2.1 & 0.1 & -1.4 & 0.7 & -1.2 & 0.0 \\
\hline Other & -0.1 & -0.5 & -0.1 & 0.4 & 1.2 & -0.7 & 0.0 \\
\hline Privatization receipts & 0.0 & 0.0 & 1.8 & 0.0 & 0.0 & 0.0 & 0.0 \\
\hline Increase in expenditure arrears & 3.7 & -2.4 & -0.4 & 1.4 & 3.6 & 3.5 & 4.0 \\
\hline Increase in principal debt arrears & 1.4 & -0.8 & 0.5 & -1.2 & 4.7 & 5.2 & 3.6 \\
\hline External & 1.4 & -0.8 & 0.5 & -1.2 & 0.8 & 1.9 & 0.1 \\
\hline Domestic & 0.0 & 0.0 & 0.0 & 0.0 & 3.9 & 3.4 & 3.5 \\
\hline \multicolumn{8}{|l|}{ Memorandum item: } \\
\hline Nominal GDP (in millions of S.I. dollars) & 1,452 & 1,561 & 1,605 & 1,523 & 1,447 & 1,605 & 1,772 \\
\hline
\end{tabular}

Sources: Data provided by the Solomon Islands authorities; and Fund staff estimates.

1/ All expenditures and debt service are presented on an accrual basis.

2/ Negative sign indicates net expenditures. 
Table 7. Solomon Islands: Central Government Revenue and Grants, 1997-2003 (In millions of Solomon Islands dollars)

\begin{tabular}{|c|c|c|c|c|c|c|c|}
\hline & 1997 & 1998 & 1999 & 2000 & 2001 & 2002 & 2003 \\
\hline Total revenue and grants & 378.9 & 458.8 & 443.1 & 360.7 & 380.0 & 296.2 & 681.3 \\
\hline Total revenue & 323.0 & 341.4 & 391.9 & 279.3 & 220.9 & 247.2 & 364.2 \\
\hline Tax revenue & 279.3 & 308.3 & 355.1 & 256.7 & 202.6 & 237.1 & 332.9 \\
\hline Income and profits & 96.6 & 129.9 & 139.5 & 96.3 & 73.6 & 73.2 & 90.0 \\
\hline Individuals & 55.0 & 56.5 & 62.2 & 54.1 & 42.7 & 37.6 & 43.8 \\
\hline Corporations & 41.7 & 73.4 & 77.3 & 42.2 & 30.9 & 35.6 & 46.2 \\
\hline Goods and services & 47.1 & 57.9 & 81.9 & 66.9 & 63.3 & 70.1 & 111.5 \\
\hline Sales taxes & 42.2 & 53.7 & 71.3 & 59.4 & 56.8 & 63.0 & 96.6 \\
\hline Excises & 4.9 & 4.3 & 10.6 & 7.6 & 6.5 & 7.1 & 14.9 \\
\hline International trade & 135.5 & 120.4 & 133.7 & 93.5 & 65.7 & 93.8 & 131.3 \\
\hline Customs and import duties & 69.9 & 72.4 & 77.3 & 52.7 & 42.7 & 54.5 & 69.1 \\
\hline Export taxes & 65.6 & 48.1 & 56.4 & 40.8 & 23.0 & 39.3 & 62.2 \\
\hline Other revenue & 43.7 & 33.1 & 36.8 & 22.6 & 18.3 & 10.1 & 31.3 \\
\hline Stamp duty & 3.7 & 2.6 & 3.7 & 1.7 & 1.9 & 3.0 & 3.5 \\
\hline Licenses and fees & 2.9 & 3.8 & 2.8 & 1.6 & 2.0 & 2.9 & 4.0 \\
\hline Miscellaneous revenue & 37.1 & 26.7 & 30.3 & 19.3 & 14.4 & 4.2 & 23.8 \\
\hline Grants & 96.6 & 111.5 & 41.6 & 57.0 & 119.4 & 40.4 & 309.5 \\
\hline Development grants & 96.6 & 75.7 & 37.1 & 46.9 & 115.7 & 33.3 & 243.7 \\
\hline Cash & 60.4 & 47.3 & 23.2 & 29.3 & 72.3 & 20.8 & 152.3 \\
\hline Noncash 1/ & 36.2 & 28.4 & 13.9 & 17.6 & 43.4 & 12.5 & 91.4 \\
\hline Recurrent budget grants & 0.0 & 35.8 & 4.5 & 10.1 & 3.7 & 7.1 & 65.8 \\
\hline
\end{tabular}

Sources: Data provided by the Solomon Islands authorities; and Fund staff estimates.

1/ Estimated. 
Table 8. Solomon Islands: Central Government Expenditure, 1997-2003 1/

(In millions of Solomon Islands dollars)

\begin{tabular}{|c|c|c|c|c|c|c|c|}
\hline & 1997 & 1998 & 1999 & 2000 & 2001 & 2002 & 2003 \\
\hline Expenditure & 481.6 & 439.9 & 486.3 & 451.8 & 517.9 & 455.6 & 670.9 \\
\hline Recurrent expenditure & 372.9 & 327.3 & 416.7 & 382.3 & 389.3 & 406.9 & 404.1 \\
\hline Compensation of employees & 162.0 & 160.0 & 180.1 & 202.1 & 190.2 & 180.0 & 163.9 \\
\hline Salaries and wages & 147.0 & 153.1 & 166.0 & 181.8 & 180.0 & 161.5 & 138.8 \\
\hline Of which: Arrears & 0.0 & 0.0 & 15.8 & 9.5 & 9.5 & 1.6 & 1.6 \\
\hline Social contributions & 15.0 & 6.9 & 14.1 & 20.3 & 10.2 & 18.6 & 25.1 \\
\hline Of which: Arrears & 2.0 & 0.0 & 3.0 & 6.9 & 9.0 & 9.0 & 9.0 \\
\hline Goods and services & 110.9 & 72.9 & 79.6 & 72.3 & 72.2 & 68.3 & 88.6 \\
\hline Of which: Arrears & 17.0 & 0.0 & 0.0 & 15.0 & 26.0 & 26.0 & 26.0 \\
\hline Interest & 48.8 & 11.2 & 68.2 & 51.8 & 14.5 & 50.6 & 49.8 \\
\hline To nonresidents & 8.1 & 7.8 & 8.1 & 8.9 & 16.2 & 31.9 & 36.5 \\
\hline Of which: Arrears & 7.8 & 0.8 & 5.8 & 0.0 & 4.7 & 14.2 & 19.1 \\
\hline To residents other than government & 41.7 & 3.4 & 60.1 & 42.8 & 2.9 & 18.1 & 8.3 \\
\hline Of which: Arrears & 26.5 & 0 & 0 & 2.5 & 2.5 & 2.5 & 2.5 \\
\hline Grants & 41.5 & 59.2 & 72.6 & 43.0 & 33.2 & 14.2 & 37.5 \\
\hline To international organizations & 1.4 & 12.7 & 7.8 & 2.0 & 0.0 & 0.0 & 3.3 \\
\hline To other government units & 40.1 & 46.5 & 64.8 & 41.0 & 33.2 & 14.2 & 34.2 \\
\hline Of which: Arrears & 0.0 & 0.0 & 0.0 & 0.0 & 0.0 & 0.0 & 9.5 \\
\hline Employer social benefits & 2.8 & 3.0 & 9.5 & 4.4 & 0.6 & 2.8 & 3.0 \\
\hline Other expenses & 4.1 & 2.6 & 4.3 & 3.4 & 77.3 & 89.0 & 59.0 \\
\hline Property expense other than interest & 1.0 & 0.8 & 1.7 & 1.6 & 0.3 & 0.3 & 1.8 \\
\hline Miscellaneous other expenses 2/ & 3.1 & 1.8 & 2.7 & 1.9 & 77.0 & 88.7 & 57.2 \\
\hline Nonfinancial assets & 2.8 & 3.6 & 2.3 & 3.7 & 1.3 & 0.0 & 2.3 \\
\hline Purchase & 1.5 & 2.5 & 2.2 & 3.1 & 1.3 & 0.0 & 2.3 \\
\hline Sale & 1.2 & 1.1 & 0.1 & 0.6 & 0.0 & 0.0 & 0.0 \\
\hline Development expenditure & 108.6 & 112.7 & 69.6 & 69.5 & 128.6 & 48.7 & 266.9 \\
\hline Grant financed & 96.6 & 75.7 & 37.1 & 46.9 & 115.7 & 33.3 & 243.7 \\
\hline Of which: Cash & 60.4 & 47.3 & 23.2 & 29.3 & 72.3 & 20.8 & 152.3 \\
\hline Loan financed & 12.0 & 37.0 & 32.5 & 22.6 & 12.9 & 15.4 & 23.2 \\
\hline Domestic & 12.0 & 21.8 & 20.5 & 0.0 & 0.0 & 0.0 & 0.0 \\
\hline Foreign & 0.0 & 15.2 & 12.0 & 22.6 & 12.9 & 15.4 & 23.2 \\
\hline Current balance & -50.0 & 49.9 & -20.3 & -92.9 & -169.4 & -152.6 & 25.9 \\
\hline Overall balance (above-the-line) & -62.0 & 12.9 & -52.8 & -115.5 & -182.3 & -168.0 & 2.7 \\
\hline
\end{tabular}

Sources: Data provided by the Solomon Islands authorities; and Fund staff estimates.

1/ All expenditures are presented on an accrual basis.

2 / Including compensation payments. 
Table 9. Solomon Islands: Central Government Budget Financing, 1997-2003 1/

(In millions of Solomon Islands dollars)

\begin{tabular}{|c|c|c|c|c|c|c|c|}
\hline & 1997 & 1998 & 1999 & 2000 & 2001 & 2002 & 2003 \\
\hline Total financing & 71.7 & 4.9 & 60.0 & 73.7 & 170.2 & 145.1 & 24.3 \\
\hline Foreign (net) & -5.0 & 76.7 & 31.1 & 8.7 & 72.5 & 58.1 & 7.5 \\
\hline Disbursement & 9.7 & 92.8 & 47.0 & 22.6 & 88.6 & 82.8 & 23.2 \\
\hline Amortization & 14.7 & 16.1 & 15.9 & 13.9 & 16.1 & 24.7 & 26.9 \\
\hline Debt forgiveness & 0.0 & 0.0 & 0.0 & 0.0 & 0.0 & 0.0 & 11.2 \\
\hline Domestic bank and non-bank (net) & 2.8 & -22.0 & -1.6 & 63.5 & -20.5 & -45.1 & -111.8 \\
\hline Banking sector & 2.2 & -46.5 & -0.8 & 79.7 & -47.7 & -16.1 & -111.8 \\
\hline Central bank (net) & 0.2 & -53.2 & -7.0 & 65.1 & 42.3 & 37.3 & -65.9 \\
\hline Securities & -0.9 & 0.0 & 4.7 & 0.0 & 0.0 & 0.2 & -0.1 \\
\hline Lending & 3.9 & 0.0 & -30.5 & -1.3 & 130.7 & 0.9 & 0.2 \\
\hline Drawdown in deposits & -2.8 & -53.2 & 18.7 & 66.5 & -88.4 & 36.2 & -66.0 \\
\hline Commercial banks (net) & 2.0 & 6.7 & 6.2 & 14.6 & -90.0 & -53.3 & -45.9 \\
\hline Securities & 0.4 & 6.5 & 14.8 & 4.1 & -91.2 & -51.5 & -44.9 \\
\hline Lending & 1.9 & -3.7 & 0.0 & 0.0 & 0.0 & 0.0 & 0.0 \\
\hline Drawdown in deposits & -0.4 & 3.8 & -8.5 & 10.5 & 1.2 & -1.8 & -1.0 \\
\hline Nonbank sector & 0.6 & 24.5 & -0.8 & -16.3 & 27.2 & -29.1 & 0.0 \\
\hline Development Bank & 0.0 & -0.8 & 0.0 & 0.0 & 0.0 & 0.0 & 0.0 \\
\hline National Provident Fund & 1.5 & 32.3 & 1.4 & -22.0 & 9.8 & -18.4 & 0.0 \\
\hline Other & -0.9 & -6.9 & -2.2 & 5.7 & 17.4 & -10.7 & 0.0 \\
\hline Privatization receipts & 0.0 & 0.0 & 28.5 & 0.0 & 0.0 & 0.0 & 0.0 \\
\hline Increase in expenditure arrears & 53.3 & -37.2 & -5.8 & 21.3 & 51.6 & 53.3 & 67.6 \\
\hline Interest & 34.3 & -22.3 & -12.5 & -10.1 & 7.2 & 16.8 & 21.6 \\
\hline External & 7.8 & 0.8 & 5.8 & -12.7 & 4.7 & 14.2 & 19.1 \\
\hline Domestic & 26.5 & -23.1 & -18.3 & 2.5 & 2.5 & 2.5 & 2.5 \\
\hline Other expenditure & 19.0 & -14.9 & 6.7 & 31.4 & 44.4 & 36.5 & 46.0 \\
\hline Increase in principal debt arrears & 20.6 & -12.7 & 7.7 & -18.2 & 68.1 & 80.5 & 61.1 \\
\hline External & 20.6 & -12.7 & 7.7 & -18.2 & 11.4 & 29.0 & 1.8 \\
\hline Domestic & 0.0 & 0.0 & 0.0 & 0.0 & 56.7 & 51.5 & 59.3 \\
\hline
\end{tabular}

Sources: Data provided by the Solomon Islands authorities; and Fund staff estimates.

1/ All debt servicing is presented on an accrual basis. 
Table 10. Solomon Islands: Central Government Gross Domestic Debt, 1997-2003 (In millions of Solomon Islands dollars)

\begin{tabular}{|c|c|c|c|c|c|c|c|}
\hline & 1997 & 1998 & 1999 & 2000 & 2001 & 2002 & 2003 \\
\hline Total & 355.4 & 382.8 & 371.3 & 357.4 & 480.8 & 452.8 & 467.3 \\
\hline Securities & 246.7 & 287.3 & 315.5 & 302.9 & 295.6 & 266.8 & 281.0 \\
\hline Bonds & 39.4 & 69.2 & 238.8 & 257.8 & 275.8 & 265.1 & 265.1 \\
\hline Bills & 207.3 & 218.2 & 76.6 & 45.1 & 19.9 & 1.7 & 15.9 \\
\hline \multirow[t]{2}{*}{ Loans } & 108.7 & 95.4 & 55.8 & 54.5 & 185.2 & 186.1 & 186.3 \\
\hline & \multicolumn{7}{|c|}{ (Distribution by holder) } \\
\hline Central bank & 81.6 & 81.6 & 55.8 & 54.5 & 185.2 & 186.3 & 186.4 \\
\hline Securities & 0.0 & 0.0 & 0.0 & 0.0 & 0.0 & 0.2 & 0.1 \\
\hline Bonds & 0.0 & 0.0 & 0.0 & 0.0 & 0.0 & 0.0 & 0.0 \\
\hline Bills & 0.0 & 0.0 & 0.0 & 0.0 & 0.0 & 0.2 & 0.1 \\
\hline Loans & 81.5 & 81.6 & 55.8 & 54.5 & 185.2 & 186.1 & 186.3 \\
\hline Commercial banks & 162.7 & 165.5 & 180.3 & 184.4 & 149.8 & 149.8 & 164.2 \\
\hline Securities & 159.0 & 165.5 & 180.3 & 184.4 & 149.8 & 149.8 & 164.2 \\
\hline Bonds & 4.5 & 3.5 & 118.3 & 149.8 & 149.8 & 149.8 & 149.8 \\
\hline Bills & 154.5 & 162.0 & 62.0 & 34.5 & 0.0 & 0.0 & 14.4 \\
\hline Loans & 3.7 & 0.0 & 0.0 & 0.0 & 0.0 & 0.0 & 0.0 \\
\hline National Provident Fund & 91.2 & 123.4 & 125.1 & 102.9 & 112.7 & 94.3 & 94.3 \\
\hline Securities & 67.8 & 109.6 & 125.1 & 102.9 & 112.7 & 94.3 & 94.3 \\
\hline Bonds & 16.1 & 53.8 & 110.5 & 92.3 & 94.3 & 94.3 & 94.3 \\
\hline Bills & 51.7 & 55.8 & 14.6 & 10.6 & 18.4 & 0.0 & 0.0 \\
\hline Loans & 23.4 & 13.9 & 0.0 & 0.0 & 0.0 & 0.0 & 0.0 \\
\hline Statutory corporations & 0.8 & 0.0 & 0.0 & 0.0 & 0.0 & 0.0 & 0.0 \\
\hline Securities & 0.8 & 0.0 & 0.0 & 0.0 & 0.0 & 0.0 & 0.0 \\
\hline Bonds & 0.0 & 0.0 & 0.0 & 0.0 & 0.0 & 0.0 & 0.0 \\
\hline Bills & 0.8 & 0.0 & 0.0 & 0.0 & 0.0 & 0.0 & 0.0 \\
\hline Loans & 0.0 & 0.0 & 0.0 & 0.0 & 0.0 & 0.0 & 0.0 \\
\hline Others & 19.2 & 12.2 & 10.0 & 15.7 & 33.1 & 22.5 & 22.5 \\
\hline Securities & 19.2 & 12.2 & 10.0 & 15.7 & 33.1 & 22.5 & 22.5 \\
\hline Bonds & 0.3 & 0.3 & 0.0 & 0.0 & 1.5 & 1.5 & 1.5 \\
\hline Bills & 18.8 & 11.9 & 10.0 & 15.7 & 31.6 & 21.0 & 21.0 \\
\hline
\end{tabular}

Sources: Central Bank of Solomon Islands; Ministry of Finance; and Fund staff estimates. 
Table 11. Solomon Islands: Equity Investment of the

Investment Corporation of Solomon Islands, 1997-2003

(Percent share)

\begin{tabular}{|c|c|c|c|c|c|c|c|}
\hline & 1997 & 1998 & 1999 & 2000 & 2001 & 2002 & 2003 \\
\hline \multicolumn{8}{|l|}{ Nonfinancial sector } \\
\hline \multicolumn{8}{|l|}{ Agriculture/agro-industry sectors } \\
\hline Solomon Islands Plantation Ltd. & 30 & 30 & 30 & 30 & 30 & 30 & 30 \\
\hline Kolombangara Forestry and Plantation Ltd. & 49 & 49 & 49 & 49 & 19 & 19 & 19 \\
\hline Solomon Taiyo Ltd. & 51 & 51 & 51 & 51 & $\ldots$ & $\ldots$ & $\ldots$ \\
\hline Soltai Fishing Company 1/ & $\ldots$ & $\ldots$ & $\ldots$ & $\ldots$ & 51 & 51 & 51 \\
\hline \multicolumn{8}{|l|}{ Others } \\
\hline Sasape Marina Ltd. & 100 & 100 & 100 & 100 & 100 & 100 & 100 \\
\hline Solomon Airlines & 100 & 100 & 100 & 100 & 100 & 100 & 100 \\
\hline Solomon Telekom & 58 & 58 & 58.1 & 10 & 7 & 7 & 7 \\
\hline Air Pacific & 0.7 & 0.7 & 0.7 & 0.7 & $\ldots$ & $\ldots$ & $\ldots$ \\
\hline Pacific Forum Line Ltd. & 0.5 & 0.5 & 0.5 & 0.5 & $\ldots$ & $\ldots$ & $\ldots$ \\
\hline Solomon Islands Printers & 100 & 100 & 100 & 100 & 100 & 100 & 100 \\
\hline \multicolumn{8}{|l|}{ Financial sector } \\
\hline Development Bank of Solomon Islands & 84 & 84 & 84 & 84 & 10 & 10 & 10 \\
\hline Central Bank of Solomon Islands & 100 & 100 & 100 & 100 & 100 & 100 & 100 \\
\hline
\end{tabular}

Source: Central Bank of Solomon Islands Annual Report .

1/ Incorporated to take over Solomon Taiyo's assets. The remaining 49 percent is owned by the Western Province government. 
Table 12. Solomon Islands: Summary Accounts of the Banking System, 1997-2003

(In millions of Solomon Islands dollars, end of period)

\begin{tabular}{|c|c|c|c|c|c|c|c|}
\hline & 1997 & 1998 & 1999 & 2000 & 2001 & 2002 & 2003 \\
\hline \multicolumn{8}{|l|}{ I. Central bank } \\
\hline Net foreign reserves & 143.9 & 225.0 & 240.8 & 147.7 & 91.0 & 117.5 & 248.3 \\
\hline Assets & 150.4 & 233.4 & 255.9 & 159.8 & 103.0 & 130.4 & 269.7 \\
\hline Liabilities & -6.5 & -8.4 & -15.1 & -12.1 & -12.1 & -12.9 & -21.4 \\
\hline Net domestic assets & -52.2 & -90.0 & -88.6 & 6.8 & 56.8 & 55.8 & -27.6 \\
\hline Net credit to central government & 75.1 & 21.9 & 14.9 & 80.0 & 122.3 & 159.5 & 93.6 \\
\hline Claims & 81.6 & 81.6 & 55.8 & 54.5 & 185.2 & 186.3 & 186.4 \\
\hline Deposits & -6.5 & -59.7 & -41.0 & 25.5 & -62.9 & -26.8 & -92.8 \\
\hline Credit to rest of NFPS & 0.0 & 0.0 & -0.2 & 0.0 & -0.1 & 0.0 & 0.0 \\
\hline Other items (net) & -127.3 & -111.9 & -103.2 & -73.2 & -65.4 & -103.6 & -121.2 \\
\hline Of which: Central bank bills & -47.6 & -25.5 & -8.4 & 0.0 & 0.0 & 0.0 & 0.0 \\
\hline Base money & 92.5 & 135.0 & 152.4 & 154.4 & 149.4 & 174.0 & 220.7 \\
\hline Currency outside banks & 70.8 & 81.3 & 100.1 & 88.3 & 84.7 & 91.5 & 102.7 \\
\hline Banking system reserves & 21.7 & 53.7 & 52.3 & 66.1 & 64.7 & 82.5 & 118.0 \\
\hline Currency in vault & 2.6 & 3.7 & 3.6 & 5.3 & 7.3 & 6.3 & 8.5 \\
\hline Deposits at CBSI & 19.1 & 49.9 & 48.7 & 60.9 & 57.4 & 76.1 & 109.5 \\
\hline \multicolumn{8}{|l|}{ II. Commercial banks } \\
\hline Net foreign assets & 9.8 & 2.2 & 6.6 & 1.2 & 10.6 & 14.8 & 24.7 \\
\hline Monetary reserves and CBSI securities & 66.7 & 61.5 & 60.3 & 60.9 & 64.6 & 81.3 & 115.3 \\
\hline Reserves & 21.7 & 51.5 & 52.3 & 60.9 & 64.6 & 81.3 & 115.3 \\
\hline CBSI bills & 45.0 & 10.0 & 8.0 & 0.0 & 0.0 & 0.0 & 0.0 \\
\hline Net domestic assets & 272.5 & 292.2 & 293.4 & 313.5 & 243.0 & 231.6 & 285.4 \\
\hline Net credit to central government & 154.5 & 161.2 & 167.4 & 182.2 & 148.8 & 147.0 & 160.4 \\
\hline Credit & 162.7 & 165.5 & 180.3 & 184.4 & 149.8 & 149.8 & 164.2 \\
\hline Deposits & -8.2 & -4.4 & -12.9 & -2.2 & -1.0 & -2.8 & -3.8 \\
\hline Net credit to provincial governments & -2.7 & -5.1 & -4.0 & -3.3 & -1.1 & -8.3 & -4.4 \\
\hline Credit & 0.3 & 0.2 & 0.2 & 0.2 & 0.2 & 0.8 & 0.7 \\
\hline Deposits & -3.0 & -5.3 & -4.2 & -3.5 & -1.3 & -9.0 & -5.1 \\
\hline Credit to rest of NFPS & 0.7 & 0.8 & 2.6 & 3.6 & 2.0 & 2.0 & 1.4 \\
\hline Credit to private sector & 141.2 & 177.0 & 191.7 & 195.2 & 152.7 & 171.3 & 216.0 \\
\hline Other items (net) & -23.9 & -41.7 & -64.3 & -64.1 & -59.5 & -80.4 & -87.9 \\
\hline Deposits & 349.0 & 355.9 & 360.4 & 375.6 & 318.1 & 327.7 & 425.5 \\
\hline \multicolumn{8}{|l|}{ III. Banking system } \\
\hline Net foreign assets & 153.7 & 227.3 & 247.5 & 148.9 & 101.6 & 132.2 & 273.0 \\
\hline Net domestic assets & 277.3 & 213.5 & 214.9 & 315.6 & 301.6 & 287.1 & 255.4 \\
\hline Net domestic credit & 368.8 & 355.8 & 372.4 & 457.6 & 424.7 & 471.4 & 467.0 \\
\hline Net credit to central government & 229.6 & 183.1 & 182.3 & 262.2 & 271.1 & 306.5 & 254.0 \\
\hline Credit & 244.3 & 247.1 & 236.1 & 238.9 & 335.0 & 336.1 & 350.6 \\
\hline Deposits & -14.7 & -64.1 & -53.9 & 23.3 & -63.9 & -29.6 & -96.6 \\
\hline Net credit to provincial governments & -2.7 & -5.1 & -4.0 & -3.3 & -1.1 & -8.3 & -4.4 \\
\hline Credit & 0.3 & 0.2 & 0.2 & 0.2 & 0.2 & 0.8 & 0.7 \\
\hline Deposits & -3.0 & -5.3 & -4.2 & -3.5 & -1.3 & -9.0 & -5.1 \\
\hline Credit to rest of NFPS & 0.7 & 0.8 & 2.4 & 3.6 & 1.9 & 1.8 & 1.4 \\
\hline Credit to private sector & 141.2 & 177.0 & 191.7 & 195.2 & 152.7 & 171.3 & 216.0 \\
\hline Other items (net) & -94.2 & -142.3 & -157.5 & -142.0 & -123.0 & -184.3 & -211.5 \\
\hline M2 & 431.0 & 440.7 & 462.4 & 464.5 & 403.2 & 419.3 & 528.4 \\
\hline Narrow money & 215.5 & 220.6 & 264.8 & 248.3 & 246.4 & 247.1 & 327.9 \\
\hline Currency in circulation & 70.8 & 81.3 & 100.1 & 88.3 & 84.7 & 91.5 & 102.7 \\
\hline Demand deposits & 144.6 & 139.2 & 164.6 & 160.0 & 161.6 & 155.6 & 225.2 \\
\hline Quasi-money & 215.5 & 220.1 & 197.6 & 216.2 & 156.8 & 172.2 & 200.5 \\
\hline Savings deposits & 77.1 & 74.8 & 75.8 & 82.2 & 79.6 & 67.4 & 67.5 \\
\hline Time deposits & 138.4 & 145.4 & 121.8 & 134.0 & 77.2 & 104.8 & 133.1 \\
\hline
\end{tabular}

Source: Central Bank of Solomon Islands. 
Table 13. Solomon Islands: Assets and Liabilities of the Central Bank of Solomon Islands, 1997-2003

(In millions of Solomon Islands dollars, end of period)

\begin{tabular}{lrrrrrrr}
\hline & 1997 & 1998 & 1999 & 2000 & 2001 & 2002 & 2003 \\
& & & & & & & \\
\hline & & & & & & & \\
Assets & 253.8 & 337.3 & 332.7 & 247.5 & 318.7 & 339.9 & 485.5 \\
External & 150.4 & 233.4 & 255.9 & 159.8 & 103.0 & 130.4 & 269.7 \\
Domestic & 103.4 & 103.9 & 76.7 & 87.8 & 215.7 & 209.5 & 215.8 \\
$\quad$ Central government & 81.6 & 81.6 & 55.8 & 54.5 & 185.2 & 186.3 & 186.4 \\
$\quad$ Loans & 75.1 & 75.2 & 44.7 & 43.4 & 174.1 & 175.0 & 175.2 \\
$\quad$ Securities & 6.4 & 6.4 & 11.1 & 11.1 & 11.1 & 11.3 & 11.2 \\
Other domestic assets & 21.9 & 22.3 & 21.1 & 33.2 & 30.6 & 23.4 & 29.4 \\
$\quad$ Securities and investments & 4.2 & 4.2 & 4.2 & 4.2 & 3.4 & 2.0 & 1.3 \\
Other & 17.7 & 18.1 & 16.9 & 29.1 & 27.3 & 21.4 & 28.0 \\
& & & & & & & \\
Liabilities & 254.7 & 337.3 & 332.8 & 247.5 & 320.3 & 340.6 & 485.5 \\
External & 6.5 & 8.4 & 15.1 & 12.1 & 12.1 & 12.9 & 21.4 \\
Domestic & 248.2 & 329.0 & 317.7 & 235.4 & 308.3 & 327.7 & 464.1 \\
Currency issued & 73.4 & 85.1 & 103.7 & 93.6 & 92.0 & 97.8 & 111.2 \\
Deposits & 26.9 & 113.2 & 91.6 & 36.0 & 120.6 & 103.0 & 202.5 \\
$\quad$ Banks & 19.1 & 49.9 & 48.7 & 60.9 & 57.4 & 76.1 & 109.5 \\
Central government & 6.5 & 59.7 & 41.0 & -25.5 & 62.9 & 26.8 & 92.8 \\
Other & 1.3 & 3.5 & 1.9 & 0.6 & 0.3 & 0.1 & 0.2 \\
Central bank bills & 47.6 & 25.5 & 8.4 & 0.0 & 0.0 & 0.0 & 0.0 \\
Other (including provisions) & 39.9 & 9.2 & 6.9 & -2.0 & -0.2 & 177.9 & 176.1 \\
Capital & 60.3 & 96.1 & 107.1 & 107.9 & 95.9 & -51.0 & -25.8 \\
& & & & & & & \\
\hline & & & & & & &
\end{tabular}

Source: Central Bank of Solomon Islands. 
Table 14. Solomon Islands: Assets and Liabilities of Commercial Banks, 1997-2003 (In millions of Solomon Islands dollars, end of period)

\begin{tabular}{|c|c|c|c|c|c|c|c|}
\hline & 1997 & 1998 & 1999 & 2000 & 2001 & 2002 & 2003 \\
\hline Assets & 425.1 & 452.8 & 502.2 & 496.9 & 452.9 & 493.8 & 612.2 \\
\hline External & 19.2 & 6.3 & 30.8 & 12.4 & 30.7 & 39.9 & 55.2 \\
\hline Domestic & 405.9 & 448.6 & 471.4 & 488.2 & 422.2 & 455.0 & 559.7 \\
\hline Cash & 2.6 & 3.7 & 3.6 & 5.3 & 7.3 & 6.3 & 8.5 \\
\hline Deposits at central bank & 19.1 & 49.9 & 48.7 & 60.9 & 57.4 & 76.1 & 109.5 \\
\hline Securities & 204.0 & 175.5 & 188.3 & 184.4 & 149.8 & 149.8 & 164.2 \\
\hline Treasury bills & 154.5 & 162.0 & 62.0 & 34.5 & 0.0 & 0.0 & 14.4 \\
\hline Other government securities & 4.5 & 3.5 & 118.3 & 149.8 & 149.8 & 149.8 & 149.8 \\
\hline Central bank securities (Bokolo bills) & 45.0 & 10.0 & 8.0 & 0.0 & 0.0 & 0.0 & 0.0 \\
\hline Loans and advances & 145.9 & 178.0 & 194.5 & 199.0 & 154.9 & 174.1 & 218.1 \\
\hline Central government & 3.7 & 0.0 & 0.0 & 0.0 & 0.0 & 0.0 & 0.0 \\
\hline Provincial governments & 0.3 & 0.2 & 0.2 & 0.2 & 0.2 & 0.8 & 0.7 \\
\hline Statutory corporations & 0.7 & 0.8 & 2.6 & 3.6 & 2.0 & 2.0 & 1.4 \\
\hline Other & 141.2 & 177.0 & 191.7 & 195.2 & 152.7 & 171.3 & 216.0 \\
\hline Premises, equipment, and other & 34.3 & 41.5 & 36.3 & 39.5 & 52.9 & 48.7 & 59.4 \\
\hline Liabilities & 425.2 & 452.8 & 502.2 & 495.3 & 452.4 & 493.5 & 611.9 \\
\hline External & 9.4 & 4.1 & 24.2 & 11.2 & 20.1 & 25.2 & 30.5 \\
\hline Domestic & 415.8 & 448.7 & 478.1 & 484.1 & 432.4 & 468.3 & 581.4 \\
\hline Deposits & 360.1 & 365.5 & 377.5 & 381.2 & 320.4 & 339.6 & 434.4 \\
\hline Central government & 8.2 & 4.4 & 12.9 & 2.2 & 1.0 & 2.8 & 3.8 \\
\hline Provincial governments & 3.0 & 5.3 & 4.2 & 3.5 & 1.3 & 9.0 & 5.1 \\
\hline Statutory corporations & 37.2 & 34.9 & 35.6 & 40.2 & 13.3 & 17.3 & 13.4 \\
\hline Other & 311.8 & 321.0 & 324.7 & 335.4 & 304.9 & 310.4 & 412.1 \\
\hline Capital and reserves & 38.4 & 62.4 & 72.2 & 76.3 & 87.9 & 95.8 & 99.6 \\
\hline Other & 17.3 & 20.8 & 28.4 & 26.5 & 24.1 & 32.9 & 47.4 \\
\hline
\end{tabular}

Source: Central Bank of Solomon Islands. 


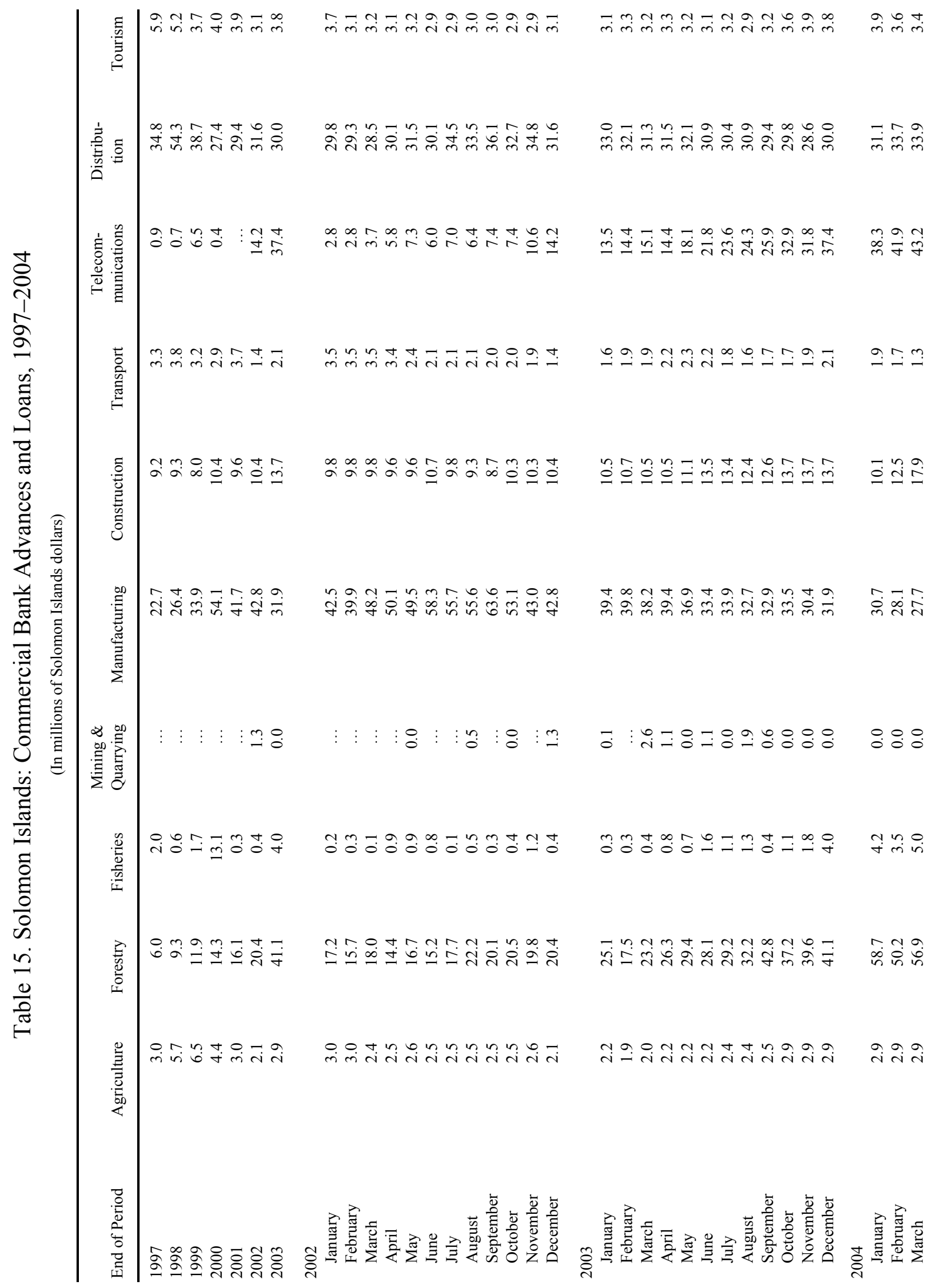




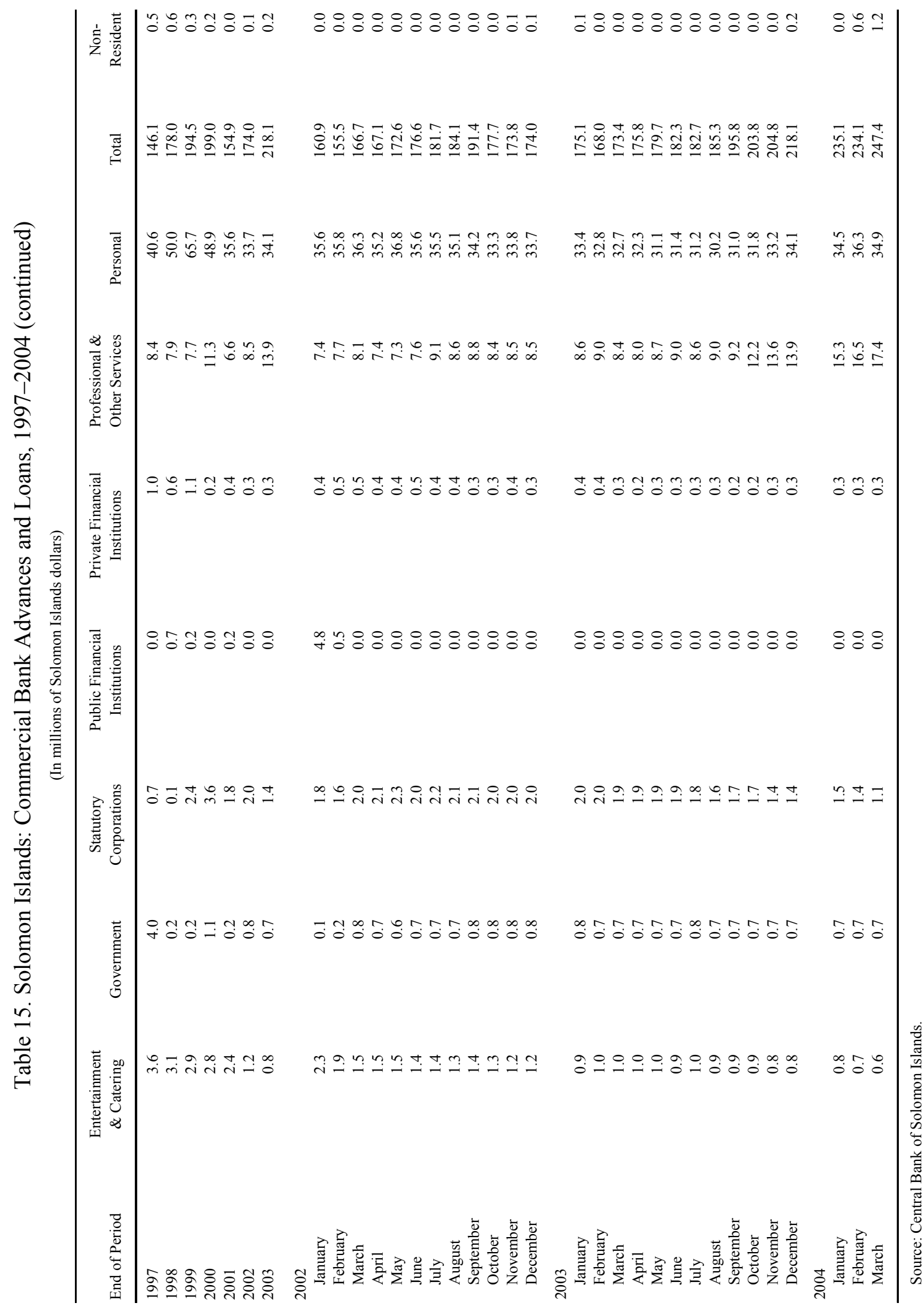




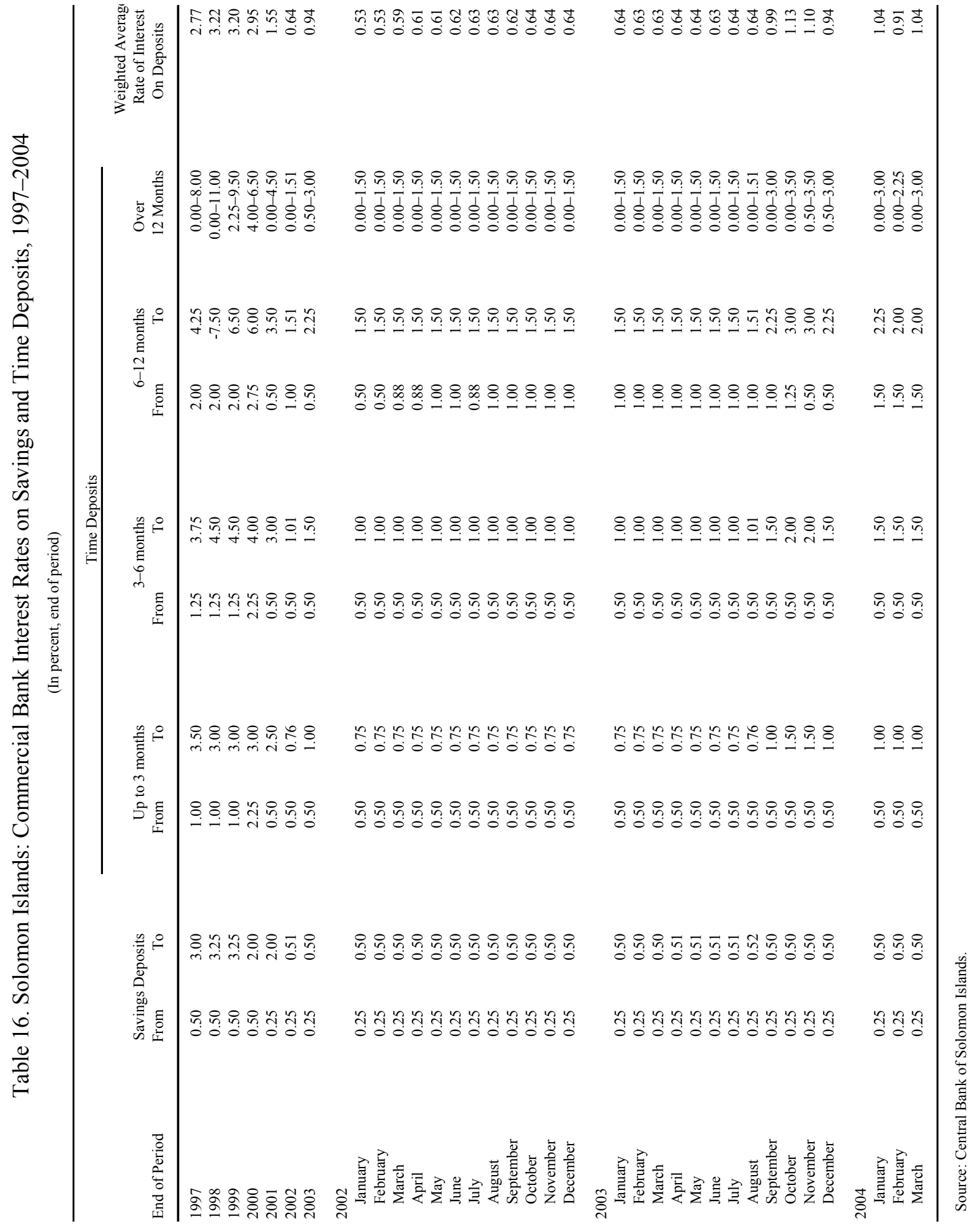


Table 17. Solomon Islands: Commercial Bank Interest Rates on Loans and Overdrafts, 1997-2004

(In percent, end of period)

\begin{tabular}{|c|c|c|c|c|}
\hline End of Period & Personal Loans & Other Loans & Overdrafts & $\begin{array}{l}\text { Weighted Average } \\
\text { Rate of Interest on } \\
\text { Loans and Overdrafts }\end{array}$ \\
\hline 1997 & $15.00-19.50$ & $10.00-18.50$ & $14.00-18.50$ & 15.71 \\
\hline 1998 & $14.00-15.00$ & $10.00-16.25$ & $14.00-15.75$ & 14.12 \\
\hline 1999 & $14.00-15.00$ & $10.00-16.25$ & $14.00-15.75$ & 14.12 \\
\hline 2000 & $14.00-17.50$ & $10.00-21.50$ & $10.00-18.00$ & 15.09 \\
\hline 2001 & $14.00-17.50$ & $10.00-21.50$ & $10.00-20.50$ & 15.65 \\
\hline 2002 & $14.00-17.50$ & $10.50-21.50$ & $10.00-20.50$ & 15.59 \\
\hline 2003 & $14.00-17.50$ & $5.80-21.50$ & $10.00-20.50$ & 14.68 \\
\hline \multicolumn{5}{|l|}{2002} \\
\hline January & $14.00-17.50$ & $10.50-21.50$ & $10.00-20.50$ & 15.64 \\
\hline February & $14.00-17.50$ & $10.50-21.50$ & $10.00-20.50$ & 15.65 \\
\hline March & $14.00-17.50$ & $10.50-21.50$ & $10.00-20.50$ & 15.63 \\
\hline April & $14.00-17.50$ & $10.50-21.50$ & $10.00-20.50$ & 15.64 \\
\hline May & $14.00-17.50$ & $10.50-21.50$ & $10.00-20.50$ & 15.64 \\
\hline June & $14.00-17.50$ & $10.50-21.50$ & $10.00-20.50$ & 15.63 \\
\hline July & $14.00-17.50$ & $10.50-21.50$ & $10.00-20.50$ & 15.62 \\
\hline August & $14.00-17.50$ & $10.50-21.50$ & $10.00-20.50$ & 15.65 \\
\hline September & $14.00-17.50$ & $10.50-21.50$ & $10.00-20.50$ & 15.64 \\
\hline October & $14.00-17.50$ & $10.50-21.50$ & $10.00-20.50$ & 15.58 \\
\hline November & $14.00-17.50$ & $10.50-21.50$ & $10.00-20.50$ & 15.58 \\
\hline December & $14.00-17.50$ & $10.50-21.50$ & $10.00-20.50$ & 15.59 \\
\hline \multicolumn{5}{|l|}{2003} \\
\hline January & $14.00-17.50$ & $10.50-21.50$ & $10.00-20.50$ & 15.58 \\
\hline February & $14.00-17.50$ & $10.50-21.50$ & $10.00-20.50$ & 15.59 \\
\hline March & $14.00-17.50$ & $10.50-21.50$ & $10.00-20.50$ & 15.58 \\
\hline April & $14.00-17.50$ & $10.50-21.50$ & $10.00-20.50$ & 15.58 \\
\hline May & $14.00-17.50$ & $10.50-21.50$ & $10.00-20.50$ & 15.58 \\
\hline June & $14.00-17.50$ & $10.50-21.50$ & $10.00-20.50$ & 15.58 \\
\hline July & $14.00-17.50$ & $10.50-21.50$ & $10.00-20.50$ & 15.60 \\
\hline August & $14.00-17.50$ & $10.50-21.50$ & $10.00-20.50$ & 15.59 \\
\hline September & $14.00-17.50$ & $10.50-21.50$ & $10.00-20.50$ & 15.39 \\
\hline October & $14.00-17.50$ & $10.50-21.50$ & $10.00-20.50$ & 15.53 \\
\hline November & $14.00-17.50$ & $5.80-21.50$ & $10.00-20.50$ & 14.72 \\
\hline December & $14.00-17.50$ & $5.80-21.50$ & $10.00-20.50$ & 14.68 \\
\hline \multicolumn{5}{|l|}{2004} \\
\hline January & $14.00-17.50$ & $5.90-21.50$ & $10.00-20.50$ & 14.73 \\
\hline February & $14.00-17.50$ & $5.90-21.50$ & $10.00-20.50$ & 14.72 \\
\hline March & $14.50-17.50$ & $5.90-21.50$ & $10.00-20.50$ & 14.75 \\
\hline
\end{tabular}

Source: Central Bank of Solomon Islands. 


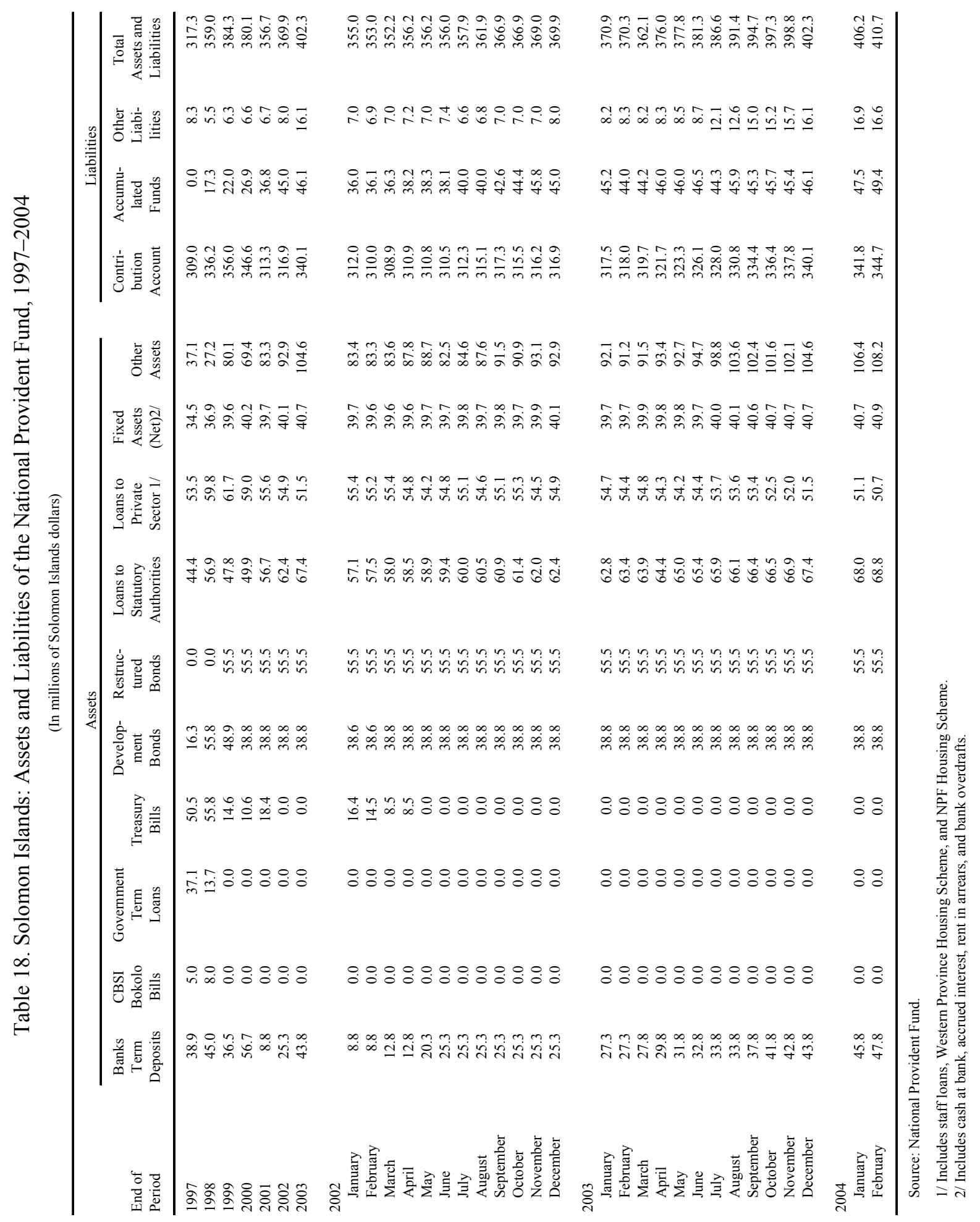


Table 19. Solomon Islands: Income Statement of the National Provident Fund, 1998-2003 1/ (In millions of Solomon Islands dollars)

\begin{tabular}{|c|c|c|c|c|c|c|}
\hline & 1998 & 1999 & 2000 & 2001 & 2002 & 2003 \\
\hline Interest income & 27.9 & 28.8 & 27.2 & 23.8 & 22.2 & 22.4 \\
\hline Non-interest income & 8.3 & 13.8 & 12.3 & 8.3 & 6.0 & 5.9 \\
\hline Dividends received & 0.0 & 7.4 & 6.9 & 3.9 & 0.9 & 0.9 \\
\hline Rentals & 3.9 & 4.1 & 4.2 & 3.4 & 4.2 & 3.9 \\
\hline Surcharges & 4.2 & 2.1 & 1.0 & 1.0 & 0.9 & 0.9 \\
\hline Sundry income & 0.2 & 0.1 & 0.1 & 0.0 & 0.0 & 0.1 \\
\hline Profit on sales of assets & 0.0 & 0.1 & 0.1 & 0.0 & 0.0 & 0.1 \\
\hline Operating income & 36.2 & 42.6 & 39.5 & 32.1 & 28.2 & 28.3 \\
\hline Less: Operating expenses & 13.0 & 14.0 & 16.1 & 13.7 & 16.0 & 18.1 \\
\hline Administration & 12.0 & 12.5 & 14.3 & 11.8 & 15.6 & 17.8 \\
\hline Members & 1.0 & 1.5 & 1.8 & 1.9 & 0.4 & 0.3 \\
\hline Net operating income & 23.2 & 28.6 & 23.4 & 18.4 & 12.2 & 10.2 \\
\hline Interest appropriated to members & 20.0 & 23.1 & 19.7 & 7.4 & 8.2 & 6.8 \\
\hline Transfer to reserves & 3.2 & 5.5 & 3.7 & 11.0 & 4.0 & 3.4 \\
\hline
\end{tabular}

Sources: Central Bank of Solomon Islands; and NPF Off-Site Supervision Report, October 2003.

1/ Financial year ending in June. 


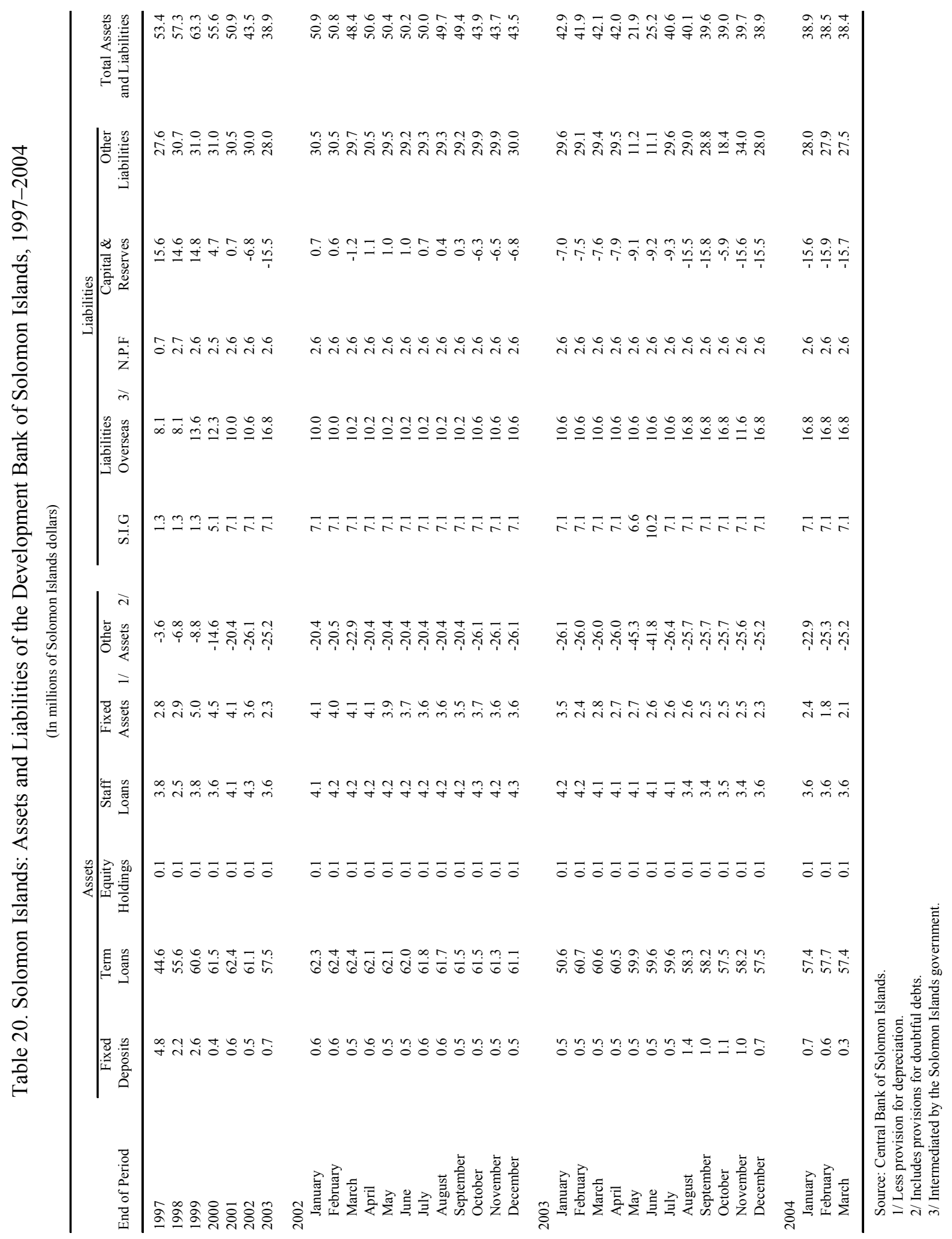


Table 21. Solomon Islands: Income Statement of the Development Bank of Solomon Islands, 1998-2003

(In millions of Solomon Islands dollars)

\begin{tabular}{|c|c|c|c|c|c|c|}
\hline & 1998 & 1999 & 2000 & 2001 & 2002 & 2003 \\
\hline Interest income & 6.9 & 8.3 & 7.9 & 6.4 & 4.5 & 4.1 \\
\hline Interest on loans & 6.7 & 8.2 & 7.9 & 6.3 & 4.5 & 4.1 \\
\hline Interest on short-term deposits & 0.2 & 0.1 & 0.0 & 0.0 & 0.0 & 0.0 \\
\hline Less: borrowing costs & 2.5 & 2.4 & 2.2 & 2.6 & 2.2 & 2.1 \\
\hline Net interest income & 4.4 & 5.9 & 5.7 & 3.8 & 2.2 & 2.0 \\
\hline Noninterest income & 1.0 & 0.4 & 0.3 & 0.4 & 0.6 & 0.6 \\
\hline Fees & 0.9 & 0.2 & 0.2 & 0.1 & 0.1 & 0.0 \\
\hline Dividends & 0.0 & 0.0 & 0.0 & 0.0 & 0.0 & 0.0 \\
\hline Rents received & 0.0 & 0.0 & 0.0 & 0.0 & 0.0 & 0.0 \\
\hline Other income & 0.1 & 0.1 & 0.1 & 0.3 & 0.4 & 0.6 \\
\hline Profit from sale of fixed assets & 0.0 & 0.0 & 0.0 & 0.0 & 0.1 & 0.0 \\
\hline Operating income after borrowing costs & 5.4 & 6.3 & 6.0 & 4.3 & 2.9 & 2.6 \\
\hline Noninterest expenses & 7.3 & 14.1 & 9.1 & 11.8 & 5.3 & 8.6 \\
\hline General operating costs & 4.9 & 5.6 & 5.1 & 5.1 & 3.9 & 4.2 \\
\hline Director fees & 0.0 & 0.1 & 0.1 & 0.0 & 0.1 & 0.0 \\
\hline Audit fees & 0.2 & 0.1 & 0.2 & 0.1 & 0.3 & 0.0 \\
\hline Depreciation & 0.4 & 0.6 & 0.7 & 0.7 & 0.6 & 0.0 \\
\hline Doubtful debt provision & 1.8 & 7.7 & 3.1 & 5.8 & 0.4 & 4.4 \\
\hline \multicolumn{7}{|l|}{ Net operating income } \\
\hline Before foreign exchange gains/losses & -1.9 & -7.9 & -3.1 & -7.5 & -2.5 & -5.9 \\
\hline Foreign exchange gains/losses & 0.1 & 0.7 & 2.3 & 0.0 & -5.0 & -3.4 \\
\hline Net profit/loss for current year & -1.8 & -7.2 & -0.9 & -7.5 & -7.5 & -9.4 \\
\hline Retained profits/losses brought forward & -1.5 & -3.3 & -10.5 & -9.1 & -16.6 & -24.0 \\
\hline Transfer from reserve & 0.0 & 0.0 & 2.3 & 0.0 & 0.0 & 0.0 \\
\hline Net profit/loss for current year & -1.8 & -7.2 & -0.9 & -7.5 & -7.5 & -9.4 \\
\hline Retained profits/losses at end-year & -3.3 & -10.5 & -9.1 & -16.6 & -24.0 & -33.3 \\
\hline
\end{tabular}

Sources: Central Bank of Solomon Islands; DBSI Onsite Examination Report, December 2003; and DBSI Audited Profit and Loss Accounts. 
Table 22. Solomon Islands: Balance of Payments, 1997-2003

(In millions of Solomon Islands dollars)

\begin{tabular}{|c|c|c|c|c|c|c|c|}
\hline & 1997 & 1998 & 1999 & 2000 & 2001 & 2002 & $\begin{array}{r}\text { Est. } \\
2003\end{array}$ \\
\hline Current account balance & -82.2 & -24.9 & 50.1 & -161.2 & -185.9 & -109.2 & 24.3 \\
\hline Trade balance & -152.9 & -7.1 & 50.5 & -167.7 & -229.5 & -27.1 & -82.5 \\
\hline Merchandise exports, f.o.b. & 648.7 & 608.3 & 589.0 & 331.3 & 248.7 & 393.0 & 557.0 \\
\hline Timber & 309.4 & 196.3 & 250.7 & 224.4 & 190.5 & 257.1 & 371.4 \\
\hline Fish & 182.4 & 194.2 & 159.0 & 41.2 & 37.3 & 70.8 & 92.9 \\
\hline Minerals & 0.0 & 0.0 & 25.6 & 1.3 & 0.4 & 0.2 & 0.6 \\
\hline Palm oil & 57.4 & 97.9 & 65.1 & 6.6 & 0.2 & 0.0 & 0.0 \\
\hline Copra & 17.7 & 39.2 & 39.3 & 34.7 & 0.4 & 2.2 & 7.8 \\
\hline Cocoa & 44.5 & 30.3 & 24.4 & 9.3 & 4.5 & 27.7 & 53.2 \\
\hline Other & 37.3 & 50.5 & 24.9 & 13.8 & 15.3 & 35.0 & 31.2 \\
\hline Merchandise imports, c.i.f.1/ & 801.6 & 615.4 & 538.5 & 499.0 & 478.1 & 420.1 & 639.5 \\
\hline Of which: Petroleum & 100.7 & 103.7 & 75.2 & 93.4 & 75.8 & 75.6 & 87.9 \\
\hline Services and income (net) & -77.4 & -73.7 & -7.6 & 70.4 & -33.9 & -45.4 & 6.4 \\
\hline Nonfactor services (net) & -47.4 & -39.1 & 20.7 & 74.3 & -33.7 & -3.1 & 44.9 \\
\hline Factor income from abroad (net, accrual) & -30.0 & -34.5 & -28.4 & -3.9 & -0.2 & -42.3 & -38.5 \\
\hline Net current transfers & 147.0 & 55.9 & 7.2 & -64.0 & 77.4 & -36.6 & 100.4 \\
\hline Private sector & 39.5 & 21.9 & 0.3 & -67.6 & 26.5 & -82.8 & 31.7 \\
\hline Public sector & 107.5 & 34.0 & 6.9 & 3.6 & 50.9 & 46.2 & 68.7 \\
\hline Capital account balance & 30.9 & 72.4 & -6.5 & 43.5 & 90.0 & 40.2 & 83.4 \\
\hline Government sector & -5.0 & 110.0 & 34.6 & 36.9 & 95.6 & 36.7 & 91.7 \\
\hline Monetary authorities (net) & 0.0 & -0.1 & 0.0 & 0.0 & 0.0 & 0.0 & 0.0 \\
\hline Medium and long-term lending & -5.0 & 76.8 & 31.1 & 8.7 & 72.5 & 15.9 & -3.7 \\
\hline Inflows & 9.7 & 92.8 & 47.0 & 22.6 & 88.6 & 40.6 & 23.2 \\
\hline Amortization (accrual) & 14.7 & 16.1 & 15.9 & 13.9 & 16.1 & 24.7 & 26.9 \\
\hline Investment flow (project) & 0.0 & 33.3 & 3.4 & 28.2 & 23.1 & 20.8 & 95.4 \\
\hline Private sector & 35.9 & -37.6 & -41.0 & 6.6 & -5.6 & 3.5 & -8.3 \\
\hline Investment activities & -0.6 & 0.1 & 12.9 & 12.4 & 5.4 & 7.0 & -0.7 \\
\hline Medium and long-term lending & 41.3 & -36.5 & -46.4 & -2.5 & -6.2 & -0.1 & -5.5 \\
\hline Inflows & 81.0 & 13.4 & 3.2 & 1.9 & 0.2 & 3.1 & 0.2 \\
\hline Amortization & 39.7 & 49.9 & 49.7 & 4.4 & 6.4 & 3.2 & 5.7 \\
\hline Other flows & -4.8 & -1.3 & -7.5 & -3.4 & -4.8 & -3.5 & -2.1 \\
\hline Overall balance (accrual) & -52.4 & 47.5 & 43.6 & -117.7 & -96.0 & -69.0 & 107.7 \\
\hline Commercial bank holdings (increase) & 6.1 & -12.9 & 24.5 & -18.4 & 18.2 & 9.3 & 15.2 \\
\hline Errors and omissions & 79.6 & 42.7 & -1.1 & -10.3 & -14.8 & 73.0 & 32.2 \\
\hline Exceptional financing & 12.6 & -20.1 & 4.5 & 13.6 & 72.2 & 32.7 & 14.6 \\
\hline Interest arrears & 6.1 & -2.0 & -1.5 & 5.9 & 13.4 & 26.5 & 21.0 \\
\hline Amortization arrears & 6.5 & -18.1 & 6.0 & 7.7 & 12.6 & 22.4 & 11.1 \\
\hline Pending foreign exchange import requests & 0.0 & 0.0 & 0.0 & 0.0 & 46.2 & -16.2 & -17.5 \\
\hline Debt forgiveness & 0.0 & 0.0 & 0.0 & 0.0 & 0.0 & 0.0 & 11.2 \\
\hline Overall balance (cash) & 33.8 & 83.0 & 22.5 & -96.1 & -56.8 & 27.4 & 139.3 \\
\hline
\end{tabular}

Sources: Data provided by the Solomon Islands authorities; and Fund staff estimates.

1/ Including pending foreign exchange import requests; value for 2003 reflects customs clearance data. 
Table 23. Solomon Islands: Balance of Payments, 1997-2003

(In millions of U.S. dollars)

\begin{tabular}{|c|c|c|c|c|c|c|c|}
\hline & 1997 & 1998 & 1999 & 2000 & 2001 & 2002 & $\begin{array}{l}\text { Est. } \\
2003\end{array}$ \\
\hline Current account balance & -21.7 & -5.1 & 10.4 & -31.7 & -35.1 & -15.7 & 3.2 \\
\hline Trade balance & -41.1 & -1.5 & 10.4 & -32.9 & -43.5 & -4.0 & -11.0 \\
\hline Merchandise exports, f.o.b. & 174.5 & 126.3 & 121.7 & 65.1 & 47.1 & 58.2 & 74.2 \\
\hline Timber & 83.2 & 40.8 & 51.8 & 44.1 & 36.1 & 38.1 & 49.5 \\
\hline Fish & 49.1 & 40.3 & 32.9 & 8.1 & 7.1 & 10.5 & 12.4 \\
\hline Minerals & 0.0 & 0.0 & 5.3 & 0.3 & 0.1 & 0.0 & 0.1 \\
\hline Palm oil & 15.4 & 20.3 & 13.5 & 1.3 & 0.0 & 0.0 & 0.0 \\
\hline Copra & 4.8 & 8.1 & 8.1 & 6.8 & 0.1 & 0.3 & 1.0 \\
\hline Cocoa & 12.0 & 6.3 & 5.0 & 1.8 & 0.9 & 4.1 & 7.1 \\
\hline Other & 10.0 & 10.5 & 5.1 & 2.7 & 2.9 & 5.2 & 4.2 \\
\hline Merchandise imports, c.i.f. 1/ & 215.7 & 127.8 & 111.3 & 98.1 & 90.6 & 62.3 & 85.2 \\
\hline Of which: Petroleum & 27.1 & 21.5 & 15.5 & 18.4 & 14.4 & 11.2 & 11.7 \\
\hline Services and income (net) & -20.1 & -15.3 & -1.5 & 13.8 & -6.3 & -6.3 & 0.9 \\
\hline Nonfactor services (net) & -12.8 & -8.1 & 4.3 & 14.6 & -6.4 & -0.5 & 6.0 \\
\hline Factor income from abroad (net, accrual) & -7.4 & -7.2 & -5.8 & -0.8 & 0.1 & -5.8 & -5.1 \\
\hline Net current transfers & 39.6 & 11.6 & 1.5 & -12.6 & 14.7 & -5.4 & 13.4 \\
\hline Private sector & 10.6 & 4.6 & 0.1 & -13.3 & 5.0 & -12.3 & 4.2 \\
\hline Public sector & 28.9 & 7.1 & 1.4 & 0.7 & 9.6 & 6.8 & 9.2 \\
\hline Capital account balance & 9.2 & 15.1 & -1.2 & 8.5 & 17.2 & 6.3 & 11.0 \\
\hline Government sector & -0.5 & 22.9 & 7.3 & 7.3 & 18.3 & 5.8 & 12.2 \\
\hline Monetary authorities (net) & 0.0 & 0.0 & 0.0 & 0.0 & 0.0 & 0.0 & 0.0 \\
\hline Medium- and long-term lending & -0.5 & 16.0 & 6.6 & 1.7 & 13.9 & 2.7 & -0.5 \\
\hline Inflows & 2.6 & 19.3 & 9.7 & 4.4 & 16.8 & 6.0 & 3.1 \\
\hline Amortization (accrual) & 3.1 & 3.3 & 3.1 & 2.7 & 2.9 & 3.3 & 3.6 \\
\hline Investment flow (project) & 0.0 & 6.9 & 0.7 & 5.5 & 4.4 & 3.1 & 12.7 \\
\hline Private sector & 9.7 & -7.8 & -8.5 & 1.3 & -1.1 & 0.5 & -1.2 \\
\hline Investment activities & -0.1 & 0.0 & 2.7 & 2.4 & 1.0 & 1.0 & -0.2 \\
\hline Medium- and long-term lending & 11.1 & -7.6 & -9.6 & -0.5 & -1.2 & 0.0 & -0.7 \\
\hline Inflows & 21.8 & 2.8 & 0.7 & 0.4 & 0.0 & 0.5 & 0.0 \\
\hline Amortization & 10.7 & 10.4 & 10.3 & 0.9 & 1.2 & 0.5 & 0.8 \\
\hline Other flows & -1.3 & -0.3 & -1.6 & -0.7 & -0.9 & -0.5 & -0.3 \\
\hline Overall balance (accrual) & -12.5 & 9.9 & 9.2 & -23.1 & -17.9 & -9.4 & 14.3 \\
\hline Commercial bank holdings (increase) & 1.6 & -2.7 & 5.1 & -3.6 & 3.5 & 1.4 & 2.0 \\
\hline Errors and omissions & 11.2 & 7.9 & -2.7 & -2.2 & -4.5 & 7.5 & 2.8 \\
\hline Exceptional financing & 2.7 & -4.1 & 0.9 & 2.7 & 13.0 & 2.3 & 3.4 \\
\hline Interest arrears & 1.3 & -0.4 & -0.3 & 1.2 & 2.4 & 3.5 & 2.8 \\
\hline Amortization arrears & 1.4 & -3.7 & 1.2 & 1.5 & 2.3 & 3.0 & 1.5 \\
\hline Pending foreign exchange import requests & 0.0 & 0.0 & 0.0 & 0.0 & 8.3 & -4.3 & -2.4 \\
\hline Debt forgiveness & 0.0 & 0.0 & 0.0 & 0.0 & 0.0 & 0.0 & 1.5 \\
\hline Overall balance (cash) & -0.5 & 16.4 & 2.4 & -19.1 & -12.8 & -1.0 & 18.4 \\
\hline \multicolumn{8}{|l|}{ Memorandum item: } \\
\hline Exchange rate (SI\$/US\$, average) & 3.79 & 4.81 & 4.93 & 5.09 & 5.30 & 6.75 & 7.51 \\
\hline
\end{tabular}

Sources: Data provided by the Solomon Islands authorities; and Fund staff estimates.

1/ Including pending foreign exchange import requests; value for 2003 reflects customs clearance data. 
Table 24. Solomon Islands: Trade Indicators, 1997-2003

\begin{tabular}{|c|c|c|c|c|c|c|c|}
\hline & 1997 & 1998 & 1999 & 2000 & 2001 & 2002 & $\begin{array}{r}\text { Est. } \\
2003\end{array}$ \\
\hline & \multicolumn{7}{|c|}{ (Percentage change) } \\
\hline Terms of trade & 23.1 & -7.0 & 15.8 & -11.0 & -11.4 & 30.5 & .. \\
\hline \multicolumn{8}{|l|}{ Export indices } \\
\hline Value & 7.0 & -27.6 & -3.6 & -46.5 & -27.6 & 23.6 & 27.4 \\
\hline Volume & -7.1 & -10.7 & -15.5 & -41.7 & -14.9 & -5.0 & $\ldots$ \\
\hline Unit price & 15.3 & -19.0 & 14.0 & -8.2 & -15.0 & 30.1 & $\ldots$ \\
\hline \multicolumn{8}{|l|}{ Import indices } \\
\hline Value & 38.5 & -40.7 & -12.9 & -11.9 & -7.6 & -31.3 & 36.8 \\
\hline Volume & 49.9 & -32.0 & -11.5 & -14.6 & -3.8 & -31.0 & 26.2 \\
\hline Unit price & -6.4 & -12.9 & -1.6 & 3.2 & -4.0 & -0.4 & 8.5 \\
\hline & \multicolumn{7}{|c|}{ (In percent of GDP) } \\
\hline \multicolumn{8}{|c|}{ Current account balance } \\
\hline Including grants & -5.6 & -1.6 & 3.1 & -10.6 & -12.8 & -6.9 & 1.4 \\
\hline Excluding grants & -15.7 & -5.2 & 2.7 & -6.4 & -18.1 & -4.5 & -4.5 \\
\hline
\end{tabular}

Sources: Data provided by the Solomon Islands authorities; and Fund staff estimates. 
Table 25. Solomon Islands: Composition of Exports, 1997-2003

(Total values in thousands of U.S. dollars; unit values in U.S. dollars; volumes in metric tons unless noted otherwise)

\begin{tabular}{|c|c|c|c|c|c|c|c|}
\hline & 1997 & 1998 & 1999 & 2000 & 2001 & 2002 & $\begin{array}{r}\text { Est. } \\
2003\end{array}$ \\
\hline \multicolumn{8}{|c|}{ Timber, logs (cubic meters) } \\
\hline Value & 83,239 & 40,757 & 51,809 & 44,100 & 36,085 & 38,101 & 49,476 \\
\hline Unit value $1 /$ & 128 & 67 & 83 & 82 & 68 & 69 & 69 \\
\hline Volume & 650,000 & 604,000 & 622,000 & 536,000 & 534,000 & 550,000 & 714,100 \\
\hline Unit value change & $\ldots$ & -47.3 & 23.4 & -1.2 & -17.9 & 2.5 & 0.0 \\
\hline \multicolumn{8}{|l|}{ Fish } \\
\hline Value & 49,073 & 40,322 & 32,873 & 8,091 & 7,074 & 10,484 & 12,372 \\
\hline Unit value $1 /$ & 1,206 & 816 & 685 & 382 & 400 & 566 & 427 \\
\hline Volume & 40,700 & 49,390 & 47,961 & 21,163 & 17,699 & 18,520 & 28,955 \\
\hline Unit value change & $\ldots$ & -32.3 & -16.0 & -44.2 & 4.5 & 41.6 & -24.5 \\
\hline \multicolumn{8}{|l|}{ Copra } \\
\hline Value & 4,765 & 8,133 & 8,121 & 6,827 & 82 & 329 & 1,042 \\
\hline Unit value 1 / & 166 & 302 & 349 & 359 & 48 & 190 & 70 \\
\hline Volume & 28,679 & 26,971 & 23,242 & 19,004 & 1,701 & 1,731 & 14,848 \\
\hline Unit value change & $\ldots$ & 81.5 & 15.9 & 2.8 & -86.6 & 294.6 & -63.0 \\
\hline \multicolumn{8}{|l|}{ Cocoa } \\
\hline Value & 11,973 & 6,288 & 5,042 & 1,823 & 859 & 4,109 & 7,085 \\
\hline Unit value 1/ & 3,070 & 1,820 & 2,105 & 787 & 422 & 1,413 & 1,545 \\
\hline Volume & 3,900 & 3,454 & 2,395 & 2,316 & 2,038 & 2,907 & 4,587 \\
\hline Unit value change & $\ldots$ & -40.7 & 15.6 & -62.6 & -46.4 & 235.2 & 9.3 \\
\hline \multicolumn{8}{|l|}{ Palm oil } \\
\hline Value & 15,445 & 20,332 & 13,465 & 1,290 & $\ldots$ & $\ldots$ & $\ldots$ \\
\hline Unit value $1 /$ & 534 & 699 & 1,046 & 1,021 & $\ldots$ & $\ldots$ & $\ldots$ \\
\hline Volume & 28,900 & 29,077 & 12,877 & 1,263 & $\ldots$ & $\ldots$ & $\ldots$ \\
\hline Unit value change & $\ldots$ & 30.8 & 49.5 & -2.3 & $\ldots$ & $\ldots$ & $\ldots$ \\
\hline Other (value) & 10,029 & 10,479 & 10,433 & 2,972 & 3,017 & 5,210 & 4,229 \\
\hline Total exports, f.o.b. & 174,525 & 126,311 & 121,742 & 65,102 & 47,118 & 58,232 & 74,203 \\
\hline
\end{tabular}

Sources: Data provided by the Solomon Islands authorities; and Fund staff estimates.

1/ Unit values reported are implied by data on the total volume and value of exports. 
Table 26. Solomon Islands: Composition of Imports, 1997-2003

\begin{tabular}{|c|c|c|c|c|c|c|c|}
\hline & 1997 & 1998 & 1999 & 2000 & 2001 & 2002 & $\begin{array}{r}\text { Est. } \\
2003\end{array}$ \\
\hline & \multicolumn{7}{|c|}{ (In thousands of U.S. dollars) } \\
\hline Oil imports & 27,097 & 21,536 & 15,535 & 18,357 & 14,352 & 11,426 & 11,710 \\
\hline Food imports & 23,160 & 17,056 & 17,161 & 15,595 & 20,547 & 16,224 & 14,962 \\
\hline Beverages \& tobacco & 2,300 & 1,904 & 1,271 & 1,003 & 1,762 & 1,660 & 924 \\
\hline Plants, vehicles \& transport equipment & 33,300 & 25,235 & 26,362 & 17,340 & 10,102 & 8,451 & 8,588 \\
\hline Building \& construction materials & $\ldots$ & 7,071 & 6,897 & 5,009 & 4,278 & 3,489 & 7,201 \\
\hline Chemical & $\ldots$ & 2,761 & 3,053 & 1,772 & 2,604 & 1,716 & 1,879 \\
\hline Other imports & $\ldots$ & 52,228 & 41,026 & 38,974 & 28,192 & 22,292 & 22,284 \\
\hline \multirow[t]{2}{*}{ Total imports (c.i.f.) $1 /$} & 215,657 & 127,792 & 111,305 & 98,050 & 81,837 & 65,257 & 67,548 \\
\hline & \multicolumn{7}{|c|}{ (In percent of total imports) } \\
\hline Oil imports & 12.6 & 16.9 & 14.0 & 18.7 & 17.5 & 17.5 & 17.3 \\
\hline Food imports & 10.7 & 13.3 & 15.4 & 15.9 & 25.1 & 24.9 & 22.2 \\
\hline Beverages and tobacco & 1.1 & 1.5 & 1.1 & 1.0 & 2.2 & 2.5 & 1.4 \\
\hline Plants, vehicles, and transport equipment & 15.4 & 19.7 & 23.7 & 17.7 & 12.3 & 12.9 & 12.7 \\
\hline Building and construction materials & $\ldots$ & 5.5 & 6.2 & 5.1 & 5.2 & 5.3 & 10.7 \\
\hline Chemical & $\ldots$ & 2.2 & 2.7 & 1.8 & 3.2 & 2.6 & 2.8 \\
\hline \multirow[t]{2}{*}{ Other imports } & $\ldots$ & 40.9 & 36.9 & 39.7 & 34.4 & 34.2 & 33.0 \\
\hline & \multicolumn{7}{|c|}{ (Annual percentage change) } \\
\hline Import value (in U.S. dollar terms) & 38.5 & -40.7 & -12.9 & -11.9 & -7.6 & -31.3 & 36.8 \\
\hline Import volume & 49.9 & -32.0 & -11.5 & -14.6 & -3.8 & -31.0 & 26.2 \\
\hline Import unit value (in U.S. dollar terms) & -6.4 & -12.9 & -1.6 & 3.2 & -4.0 & -0.4 & 8.5 \\
\hline
\end{tabular}

Sources: Data provided by the Solomon Islands authorities; and Fund staff estimates.

1/ The total imports value shown does not incorporate pending foreign exchange import requests and the 2003 figure is based on banking rather than customs clearance data. 
Table 27. Solomon Islands: Exports by Country of Destination, 1997-2003

(Percent of total)

\begin{tabular}{|c|c|c|c|c|c|c|c|}
\hline & 1997 & 1998 & 1999 & 2000 & 2001 & 2002 & 2003 \\
\hline $\begin{array}{l}\text { Industrial countries } \\
\text { Of which. }\end{array}$ & 64.7 & 48.7 & 52.8 & 36.9 & 32.0 & 24.7 & 23.7 \\
\hline Japan & 51.0 & 28.6 & 32.9 & 21.7 & 21.5 & 20.9 & 17.9 \\
\hline European Union & 11.3 & 16.0 & 17.3 & 11.0 & 5.2 & 1.9 & 2.1 \\
\hline Australia & 1.5 & 2.0 & 1.4 & 2.7 & 1.7 & 0.9 & 2.1 \\
\hline New Zealand & 0.3 & 0.3 & 0.5 & 0.7 & 0.3 & 0.3 & 0.5 \\
\hline Other & 0.5 & 1.7 & 0.7 & 0.8 & 3.4 & 0.8 & 1.2 \\
\hline $\begin{array}{l}\text { Asia: 1/ } \\
\text { Of which: }\end{array}$ & 34.5 & 49.0 & 47.0 & 62.9 & 67.5 & 74.9 & 76.0 \\
\hline Korea & 14.8 & 5.1 & 8.1 & 17.0 & 19.4 & 16.1 & 15.2 \\
\hline China & 1.0 & 3.2 & 9.6 & 16.7 & 11.5 & 21.9 & 25.8 \\
\hline Philippines & 8.2 & 5.9 & 12.1 & 10.1 & 9.2 & 10.2 & 9.9 \\
\hline Thailand & 2.4 & 20.2 & 8.3 & 5.3 & 9.3 & 7.5 & 6.2 \\
\hline Singapore & 2.3 & 2.9 & 0.3 & 0.9 & 1.2 & 4.0 & 5.6 \\
\hline Malaysia & 1.9 & 2.4 & 2.4 & 1.7 & 1.6 & 2.4 & 2.3 \\
\hline Papua New Guinea & 0.4 & 0.5 & 0.6 & 1.2 & 1.6 & 1.6 & 1.5 \\
\hline Other & 11.7 & 14.7 & 17.7 & 20.2 & 22.8 & 21.4 & 19.6 \\
\hline Other countries & 0.8 & 2.3 & 0.2 & 0.2 & 0.5 & 0.3 & 0.3 \\
\hline
\end{tabular}

Source: IMF, Direction of Trade Statistics.

1/ Excluding Japan. 
Table 28. Solomon Islands: Imports by Country of Origin, 1997-2003

(Percent of total)

\begin{tabular}{|c|c|c|c|c|c|c|c|}
\hline & 1997 & 1998 & 1999 & 2000 & 2001 & 2002 & 2003 \\
\hline $\begin{array}{l}\text { Industrial countries } \\
\text { Of which: }\end{array}$ & 59.7 & 60.4 & 63.2 & 46.2 & 47.5 & 43.2 & 40.8 \\
\hline Australia & 40.7 & 43.0 & 38.5 & 27.5 & 29.3 & 31.7 & 28.0 \\
\hline Japan & 10.3 & 6.4 & 10.6 & 5.4 & 3.6 & 2.3 & 3.1 \\
\hline New Zealand & 5.4 & 5.3 & 6.3 & 5.6 & 5.0 & 5.1 & 5.2 \\
\hline United States & 1.3 & 2.1 & 1.1 & 5.2 & 7.2 & 2.0 & 1.7 \\
\hline Other & 2.1 & 3.7 & 6.7 & 2.6 & 2.4 & 2.1 & 2.9 \\
\hline $\begin{array}{l}\text { Asia: 1/ } \\
\text { Of which: }\end{array}$ & 37.7 & 37.4 & 34.7 & 50.3 & 48.6 & 52.0 & 54.5 \\
\hline Singapore & 15.6 & 8.4 & 15.1 & 25.1 & 18.6 & 19.9 & 23.2 \\
\hline China & 3.3 & 3.2 & 2.9 & 3.2 & 3.9 & 2.8 & 3.7 \\
\hline Fiji & 1.6 & 2.1 & 1.9 & 3.1 & 3.8 & 4.6 & 4.6 \\
\hline Papua New Guinea & 1.5 & 2.0 & 1.8 & 3.1 & 3.7 & 4.5 & 4.4 \\
\hline Korea & 1.5 & 6.9 & 0.7 & 0.7 & 0.5 & 0.9 & 0.8 \\
\hline Thailand & 2.1 & 2.3 & 2.0 & 1.1 & 2.7 & 0.6 & 1.0 \\
\hline Malaysia & 3.6 & 1.1 & 1.6 & 1.8 & 1.2 & 1.0 & 1.0 \\
\hline Other & 8.6 & 11.3 & 8.6 & 12.2 & 14.4 & 17.5 & 15.7 \\
\hline Other countries & 2.6 & 2.2 & 2.1 & 3.4 & 3.9 & 4.8 & 4.7 \\
\hline
\end{tabular}

Source: IMF, Direction of Trade Statistics.

1/ Excluding Japan. 
Table 29. Solomon Islands: Services, Income, and Transfers, 1997-2003 (In millions of U.S. dollars)

\begin{tabular}{|c|c|c|c|c|c|c|c|}
\hline & 1997 & 1998 & 1999 & 2000 & 2001 & 2002 & $\begin{array}{r}\text { Est. } \\
2003\end{array}$ \\
\hline Services and income & -20.3 & -15.3 & -1.5 & 13.8 & -6.3 & -6.3 & 0.9 \\
\hline Nonfactor services (net) & -12.8 & -8.1 & 4.3 & 14.6 & -6.4 & -0.5 & 6.0 \\
\hline Exports & 64.2 & 59.1 & 52.5 & 48.6 & 24.7 & 16.7 & 21.2 \\
\hline Transportation & 2.6 & 1.6 & 1.1 & 0.6 & 1.2 & 1.0 & 1.0 \\
\hline Travel & 7.1 & 6.6 & 5.7 & 3.6 & 2.2 & 1.5 & 2.3 \\
\hline Communications & 0.0 & 2.2 & 2.3 & 1.8 & 0.0 & 1.2 & 0.1 \\
\hline Financial services & 0.0 & 19.1 & 19.2 & 21.7 & 7.9 & 1.8 & 0.9 \\
\hline Other & 55 & 29 & 24 & 21 & 13.4 & 11.3 & 17.0 \\
\hline Imports & 77.0 & 67.2 & 48.2 & 34.0 & 31.1 & 17.1 & 15.3 \\
\hline Transportation & 5.8 & 8.5 & 7.9 & 4.6 & 3.3 & 3.8 & 3.1 \\
\hline Travel & 9.0 & 5.6 & 7.2 & 8.7 & 6.5 & 4.3 & 4.4 \\
\hline Communications & 0 & 5 & 5 & 3 & 2 & 2 & 2 \\
\hline Financial services & 0 & 9 & 5 & 3 & 6 & 2 & 1 \\
\hline Other & 62.2 & 39.7 & 22.6 & 15.3 & 13.5 & 5.5 & 4.6 \\
\hline Factor income (net) & -7.6 & -7.2 & -5.8 & -0.8 & 0.1 & -5.8 & -5.1 \\
\hline Credit & 2.7 & 3.0 & 5.4 & 7.2 & 6.2 & 2.7 & 3.5 \\
\hline Official interest & 2.4 & 1.7 & 2.7 & 2.7 & 1.1 & 0.5 & 0.7 \\
\hline Other & 0.3 & 1.2 & 2.6 & 4.5 & 5.1 & 2.2 & 2.8 \\
\hline Debit & 10.3 & 10.1 & 11.2 & 8.0 & 6.1 & 8.5 & 8.6 \\
\hline Official interest (accrual) & 1.7 & 1.6 & 1.6 & 1.8 & 2.9 & 4.3 & 4.9 \\
\hline Other & 8.6 & 8.5 & 9.6 & 6.2 & 3.2 & 4.3 & 3.8 \\
\hline Current transfers (net) & 39.6 & 11.6 & 1.5 & -12.6 & 14.7 & -5.4 & 13.4 \\
\hline Private sector & 10.6 & 4.6 & 0.1 & -13.3 & 5.0 & -12.3 & 4.2 \\
\hline Receipts & 29.0 & 25.4 & 25.4 & 16.5 & 24.0 & 15.8 & 18.4 \\
\hline Payments & 18.4 & 20.9 & 25.3 & 29.7 & 19.0 & 28.1 & 14.2 \\
\hline Public sector & 28.9 & 7.1 & 1.4 & 0.7 & 9.6 & 6.8 & 9.2 \\
\hline Receipts & 30.6 & 10.3 & 5.0 & 2.2 & 10.0 & 7.5 & 14.3 \\
\hline Payments & 1.7 & 3.3 & 3.6 & 1.5 & 0.4 & 0.7 & 5.2 \\
\hline
\end{tabular}

Sources: Data provided by the Solomon Islands authorities; and Fund staff estimates. 
Table 30. Solomon Islands: Medium- and Long-Term Government External Debt and Disbursements, 1997-2003

(In millions of U.S. dollars)

\begin{tabular}{|c|c|c|c|c|c|c|c|}
\hline & 1997 & 1998 & 1999 & 2000 & 2001 & 2002 & 2003 \\
\hline Total debt outstanding at year-end $1 /$ & 117.4 & 122.2 & 130.5 & 125.6 & 134.2 & 151.6 & 163.9 \\
\hline Total multilateral & 69.5 & 89.3 & 95.7 & 92.2 & 87.9 & 89.8 & 99.8 \\
\hline Asian Development Bank & 36.7 & 49.9 & 49.3 & 47.0 & 44.7 & 45.2 & 49.2 \\
\hline International Development Association & 29.6 & 33.7 & 40.9 & 40.1 & 38.5 & 40.0 & 45.9 \\
\hline OPEC & 0.7 & 2.4 & 2.2 & 2.1 & 1.9 & 1.8 & 1.6 \\
\hline International Fund for Agricultural Development & 2.5 & 3.3 & 3.2 & 3.0 & 2.8 & 2.9 & 3.1 \\
\hline Total bilateral & 20.5 & 21.7 & 21.8 & 19.1 & 30.5 & 42.3 & 41.9 \\
\hline European Community & 9.1 & 6.9 & 7.2 & 6.1 & 5.8 & 6.2 & 7.3 \\
\hline European Investment Bank & 0.6 & 3.8 & 3.9 & 3.3 & 3.0 & 3.3 & 3.9 \\
\hline United Kingdom & 6.9 & 3.7 & 3.1 & 2.5 & 2.0 & 1.7 & 0.0 \\
\hline Kuwait & 2.0 & 7.1 & 6.8 & 6.3 & 5.8 & 5.3 & 4.9 \\
\hline $\mathrm{CDC}$ & 1.9 & 0.2 & 0.0 & 0.0 & 0.0 & 0.0 & 0.7 \\
\hline Taiwan Province of China & 0.0 & 0.0 & 0.9 & 0.9 & 13.9 & 25.8 & 25.0 \\
\hline Commercial creditors & 16.3 & 2.8 & 2.3 & 9.7 & 8.8 & 8.4 & 8.4 \\
\hline EFIC (Australia) & 9.4 & 0.0 & 0.0 & 7.8 & 7.3 & 7.4 & 7.8 \\
\hline Klockner (Germany) & 0.9 & 0.0 & 0.0 & 0.0 & 0.0 & 0.0 & 0.0 \\
\hline Marubeni (Hong Kong SAR) & 6.0 & 2.8 & 2.3 & 1.9 & 1.5 & 1.1 & 0.6 \\
\hline Arrears & 11.1 & 8.4 & 10.7 & 4.6 & 7.0 & 11.1 & 13.8 \\
\hline Total disbursements & 4.5 & 19.1 & 7.1 & 0.8 & 13.0 & 12.0 & 1.5 \\
\hline Multilateral & 4.4 & 19.1 & 7.1 & 0.8 & 0.0 & 0.0 & 1.5 \\
\hline Asian Development Bank & 0.0 & 16.1 & 0.0 & 0.0 & 0.0 & 0.0 & 0.0 \\
\hline International Development Association & $4 . .3$ & 3.0 & 7.1 & 0.8 & 0.0 & 0.0 & 1.5 \\
\hline OPEC & 0.0 & 0.0 & 0.0 & 0.0 & 0.0 & 0.0 & 0.0 \\
\hline International Fund for Agricultural Development & 0.1 & 0.0 & 0.0 & 0.0 & 0.0 & 0.0 & 0.0 \\
\hline Bilateral & 0.1 & 0.0 & 0.0 & 0.0 & 13.0 & 12.0 & 0.0 \\
\hline European Community & 0.0 & 0.0 & 0.0 & 0.0 & 0.0 & 0.0 & 0.0 \\
\hline European Investment Bank & 0.1 & 0.0 & 0.0 & 0.0 & 0.0 & 0.0 & 0.0 \\
\hline United Kingdom & 0.0 & 0.0 & 0.0 & 0.0 & 0.0 & 0.0 & 0.0 \\
\hline Kuwait & 0.0 & 0.0 & 0.0 & 0.0 & 0.0 & 0.0 & 0.0 \\
\hline $\mathrm{CDC}$ & 0.0 & 0.0 & 0.0 & 0.0 & 0.0 & 0.0 & 0.0 \\
\hline Taiwan Province of China & 0.0 & 0.0 & 0.0 & 0.0 & 13.0 & 12.0 & 0.0 \\
\hline Commercial creditors & 0.0 & 0.0 & 0.0 & 0.0 & 0.0 & 0.0 & 0.0 \\
\hline EFIC (Australia) & 0.0 & 0.0 & 0.0 & 0.0 & 0.0 & 0.0 & 0.0 \\
\hline Klockner (Germany) & 0.0 & 0.0 & 0.0 & 0.0 & 0.0 & 0.0 & 0.0 \\
\hline Marubeni (Hong Kong SAR) & 0.0 & 0.0 & 0.0 & 0.0 & 0.0 & 0.0 & 0.0 \\
\hline
\end{tabular}

Sources: Data provided by the Solomon Islands authorities; and Fund staff estimates.

1/ Includes arrears. 
Table 31. Solomon Islands: Medium- and Long-Term External Government Debt-Service Payments, 1997-2003

(Accrual basis; in millions of U.S. dollars)

\begin{tabular}{|c|c|c|c|c|c|c|c|}
\hline & 1997 & 1998 & 1999 & 2000 & 2001 & 2002 & 2003 \\
\hline Amortization & 3.1 & 3.3 & 3.1 & 2.7 & 2.9 & 3.3 & 3.6 \\
\hline Total multilateral & 0.6 & 1.3 & 1.2 & 1.2 & 1.3 & 1.4 & 1.8 \\
\hline Asian Development Bank & 0.4 & 0.9 & 0.9 & 0.9 & 1.0 & 1.0 & 1.1 \\
\hline International Development Association & 0.1 & 0.2 & 0.2 & 0.2 & 0.2 & 0.3 & 0.4 \\
\hline OPEC & 0.0 & 0.1 & 0.0 & 0.0 & 0.0 & 0.0 & 0.2 \\
\hline International Fund for Agricultural Development & 0.1 & 0.1 & 0.1 & 0.1 & 0.1 & 0.1 & 0.1 \\
\hline Total bilateral & 1.3 & 1.4 & 1.4 & 1.0 & 1.2 & 1.5 & 1.3 \\
\hline European Community & 0.2 & 0.0 & 0.2 & 0.1 & 0.1 & 0.3 & 0.3 \\
\hline European Investment Bank & 0.0 & 0.1 & 0.1 & 0.1 & 0.1 & 0.1 & 0.1 \\
\hline United Kingdom & 0.5 & 0.5 & 0.4 & 0.4 & 0.4 & 0.4 & 0.4 \\
\hline Kuwait & 0.4 & 0.7 & 0.4 & 0.4 & 0.6 & 0.6 & 0.4 \\
\hline $\mathrm{CDC}$ & 0.2 & 0.1 & 0.2 & 0.0 & 0.0 & 0.0 & 0.0 \\
\hline Taiwan Province of China & 0.0 & 0.0 & 0.0 & 0.0 & 0.0 & 0.1 & 0.1 \\
\hline Commercial creditors & 1.3 & 0.5 & 0.5 & 0.5 & 0.4 & 0.4 & 0.4 \\
\hline EFIC (Australia) & 0.9 & 0.1 & 0.1 & 0.1 & 0.0 & 0.0 & 0.0 \\
\hline Klockner (Germany) & 0.0 & 0.0 & 0.0 & 0.0 & 0.0 & 0.0 & 0.0 \\
\hline Marubeni (Hong Kong SAR) & 0.4 & 0.4 & 0.4 & 0.4 & 0.4 & 0.4 & 0.4 \\
\hline Interest payments & 1.7 & 1.6 & 1.6 & 1.8 & 2.9 & 4.3 & 4.9 \\
\hline Total multilateral & 0.4 & 0.8 & 0.9 & 0.9 & 0.8 & 0.8 & 0.9 \\
\hline Asian Development Bank & 0.3 & 0.5 & 0.5 & 0.5 & 0.4 & 0.5 & 0.5 \\
\hline International Development Association & 0.1 & 0.3 & 0.3 & 0.3 & 0.3 & 0.3 & 0.4 \\
\hline OPEC & 0.0 & 0.1 & 0.1 & 0.1 & 0.1 & 0.1 & 0.1 \\
\hline International Fund for Agricultural Development & 0.0 & 0.0 & 0.0 & 0.0 & 0.0 & 0.0 & 0.0 \\
\hline Total bilateral & 0.3 & 0.5 & 0.5 & 0.5 & 0.9 & 1.3 & 1.3 \\
\hline European Community & 0.1 & 0.1 & 0.1 & 0.1 & 0.0 & 0.1 & 0.1 \\
\hline European Investment Bank & 0.0 & 0.1 & 0.1 & 0.1 & 0.1 & 0.1 & 0.1 \\
\hline United Kingdom & 0.0 & 0.1 & 0.1 & 0.1 & 0.1 & 0.1 & 0.0 \\
\hline Kuwait & 0.1 & 0.3 & 0.3 & 0.2 & 0.2 & 0.2 & 0.2 \\
\hline $\mathrm{CDC}$ & 0.1 & 0.0 & 0.0 & 0.0 & 0.0 & 0.0 & 0.0 \\
\hline Taiwan Province of China & 0.0 & 0.0 & 0.0 & 0.0 & 0.5 & 0.9 & 0.9 \\
\hline Commercial creditors & 0.9 & 0.2 & 0.2 & 0.4 & 1.2 & 2.2 & 2.7 \\
\hline EFIC (Australia) & 0.4 & 0.0 & 0.0 & 0.3 & 0.3 & 0.3 & 0.3 \\
\hline Klockner (Germany) & 0.2 & 0.0 & 0.0 & 0.0 & 0.0 & 0.0 & 0.0 \\
\hline Marubeni (Hong Kong SAR) & 0.3 & 0.2 & 0.2 & 0.1 & 0.9 & 1.9 & 2.4 \\
\hline \multicolumn{8}{|l|}{ Memorandum items: } \\
\hline Rescheduling & 0.0 & 0.0 & 0.0 & 7.8 & 0.0 & 0.0 & 0.0 \\
\hline Arrears & 11.1 & 8.4 & 10.7 & 4.6 & 7.0 & 11.1 & 13.8 \\
\hline Principal & 8.0 & 5.2 & 6.5 & 2.9 & 4.7 & 7.4 & 7.6 \\
\hline Interest & 3.1 & 3.2 & 4.2 & 1.7 & 2.4 & 3.7 & 6.2 \\
\hline
\end{tabular}

Sources: Data provided by the Solomon Islands authorities; and Fund staff estimates. 
Table 32. Solomon Islands: Medium- and Long-Term

External Debt Indicators, 1997-2003

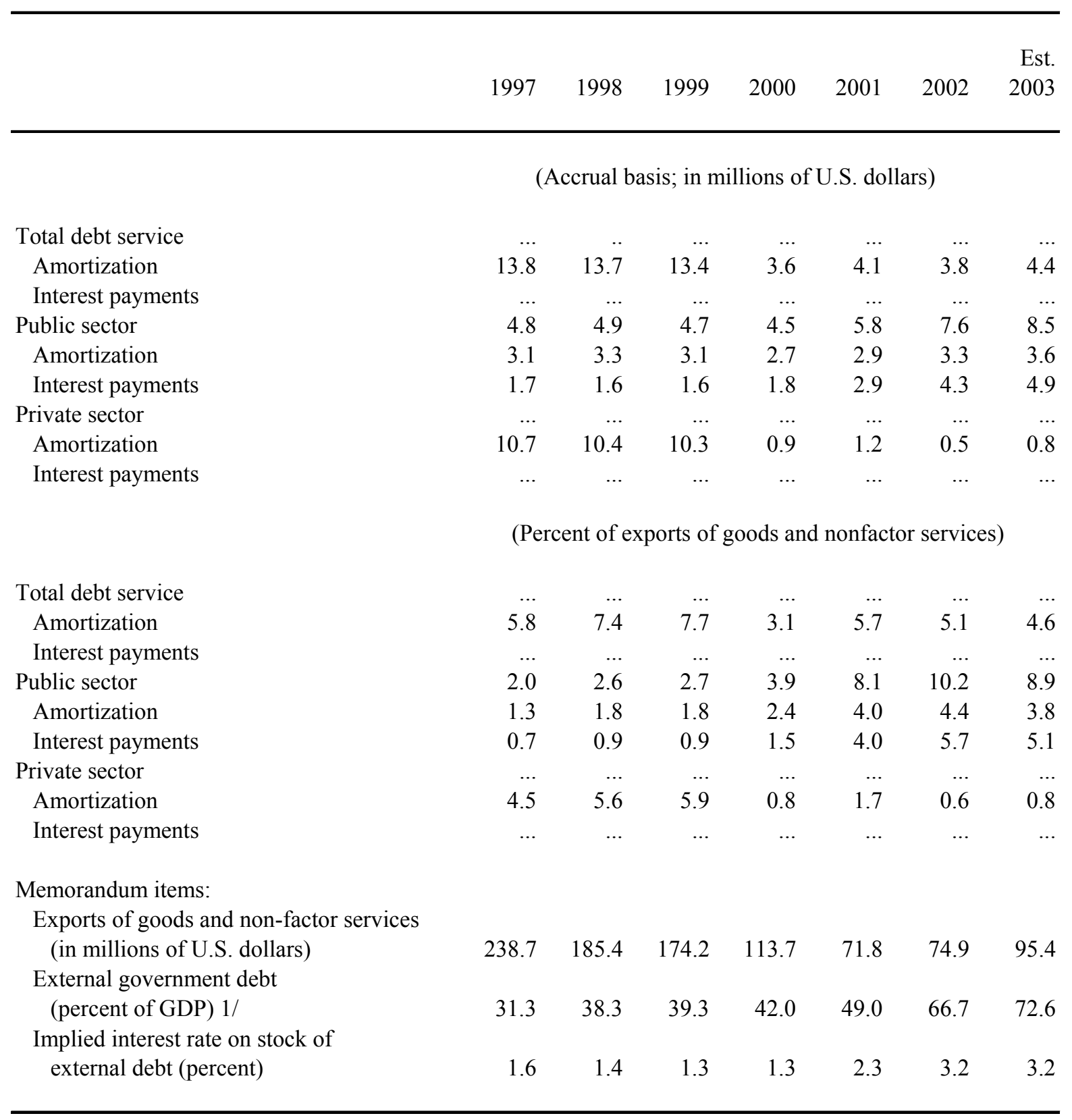

Sources: Data provided by the Solomon Islands authorities; and Fund staff estimates.

1/ Includes external debt arrears. 
Table 33. Solomon Islands: Bilateral Exchange Rates, 1997-2004

(In Solomon Islands dollars; per unit of foreign currency, end of period)

\begin{tabular}{|c|c|c|c|c|c|c|}
\hline & $\begin{array}{r}\text { Australian } \\
\text { Dollar }\end{array}$ & $\begin{array}{l}\text { Japanese } \\
\text { Yen 1/ }\end{array}$ & $\begin{array}{r}\text { New Zealand } \\
\text { Dollar }\end{array}$ & $\begin{array}{r}\text { U.S. } \\
\text { Dollar }\end{array}$ & $\begin{array}{r}\text { U.K. Pound } \\
\text { Sterling }\end{array}$ & SDR \\
\hline \multicolumn{7}{|c|}{ Annual averages } \\
\hline 1997 & 2.79 & 3.11 & 2.48 & 3.79 & 6.21 & 5.21 \\
\hline 1998 & 3.02 & 3.69 & 2.56 & 4.81 & 7.99 & 6.53 \\
\hline 1999 & 3.18 & 4.37 & 2.60 & 4.93 & 7.96 & 6.73 \\
\hline 2000 & 2.93 & 4.70 & 2.31 & 5.09 & 7.71 & 6.70 \\
\hline 2001 & 2.72 & 4.34 & 2.21 & 5.30 & 7.63 & 6.73 \\
\hline 2002 & 3.69 & 5.44 & 3.16 & 6.75 & 10.23 & 8.79 \\
\hline 2003 & 4.94 & 6.50 & 4.40 & 7.51 & 12.37 & 10.57 \\
\hline \multicolumn{7}{|l|}{2001} \\
\hline January & 2.79 & 4.40 & 2.25 & 5.11 & 7.47 & 6.63 \\
\hline February & 2.69 & 4.39 & 2.21 & 5.12 & 7.41 & 6.61 \\
\hline March & 2.53 & 4.16 & 2.11 & 5.18 & 7.39 & 6.53 \\
\hline April & 2.66 & 4.23 & 2.15 & 5.22 & 7.48 & 6.61 \\
\hline May & 2.68 & 4.41 & 2.19 & 5.25 & 7.44 & 6.59 \\
\hline June & 2.68 & 4.26 & 2.14 & 5.29 & 7.42 & 6.58 \\
\hline July & 2.67 & 4.24 & 2.18 & 5.29 & 7.54 & 6.66 \\
\hline August & 2.83 & 4.45 & 2.34 & 5.30 & 7.73 & 6.82 \\
\hline September & 2.64 & 4.49 & 2.15 & 5.36 & 7.88 & 6.91 \\
\hline October & 2.74 & 4.45 & 2.24 & 5.43 & 7.90 & 6.93 \\
\hline November & 2.85 & 4.42 & 2.26 & 5.48 & 7.81 & 6.93 \\
\hline December & 2.84 & 4.22 & 2.31 & 5.56 & 8.07 & 6.99 \\
\hline \multicolumn{7}{|l|}{2002} \\
\hline January & 2.90 & 4.30 & 2.38 & 5.71 & 8.07 & 7.09 \\
\hline February & 3.07 & 4.44 & 2.49 & 5.95 & 8.42 & 7.38 \\
\hline March & 3.17 & 4.48 & 2.60 & 5.97 & 8.50 & 7.44 \\
\hline April & 3.44 & 4.98 & 2.85 & 6.37 & 9.28 & 8.07 \\
\hline May & 3.65 & 5.17 & 3.06 & 6.43 & 9.43 & 8.30 \\
\hline June & 3.83 & 5.68 & 3.34 & 6.78 & 10.43 & 9.03 \\
\hline July & 3.96 & 6.03 & 3.38 & 7.23 & 11.32 & 9.56 \\
\hline August & 4.04 & 6.20 & 3.43 & 7.31 & 11.35 & 9.70 \\
\hline September & 3.93 & 5.95 & 3.39 & 7.23 & 11.31 & 9.56 \\
\hline October & 4.11 & 6.07 & 3.59 & 7.43 & 11.60 & 9.83 \\
\hline November & 3.99 & 5.82 & 3.52 & 7.11 & 11.04 & 9.42 \\
\hline December & 4.22 & 6.22 & 3.93 & 7.46 & 12.02 & 10.14 \\
\hline \multicolumn{7}{|l|}{2003} \\
\hline January & 4.39 & 6.27 & 4.08 & 7.46 & 12.32 & 10.27 \\
\hline February & 4.53 & 6.35 & 4.20 & 7.48 & 11.84 & 10.25 \\
\hline March & 4.54 & 6.26 & 4.15 & 7.52 & 11.88 & 10.33 \\
\hline April & 4.68 & 6.29 & 4.20 & 7.52 & 12.00 & 10.41 \\
\hline May & 4.90 & 6.35 & 4.34 & 7.52 & 12.39 & 10.68 \\
\hline June & 5.01 & 6.27 & 4.37 & 7.51 & 12.40 & 10.52 \\
\hline July & 4.91 & 6.26 & 4.38 & 7.52 & 12.11 & 10.47 \\
\hline August & 4.82 & 6.43 & 4.31 & 7.53 & 11.90 & 10.37 \\
\hline September & 5.11 & 6.76 & 4.46 & 7.51 & 12.57 & 10.74 \\
\hline October & 5.29 & 6.91 & 4.59 & 7.51 & 12.71 & 10.76 \\
\hline November & 5.41 & 6.86 & 4.81 & 7.51 & 12.92 & 10.88 \\
\hline December & 5.62 & 6.99 & 4.91 & 7.49 & 13.37 & 11.13 \\
\hline \multicolumn{7}{|l|}{2004} \\
\hline January & 5.73 & 7.07 & 5.01 & 7.49 & 13.56 & 11.10 \\
\hline February & 5.77 & 6.86 & 5.14 & 7.48 & 13.83 & 11.07 \\
\hline March & 5.68 & 7.18 & 4.92 & 7.49 & 13.74 & 11.09 \\
\hline April & 5.40 & 6.79 & 4.65 & 7.48 & 13.26 & 10.86 \\
\hline May & 5.33 & 6.75 & 4.71 & 7.46 & 13.69 & 10.96 \\
\hline
\end{tabular}

Sources: IMF, International Financial Statistics; and Fund staff estimates.

1/ Solomon Islands dollar per 100 yen. 
Table 34. Solomon Islands: Exchange Rate Indicators, 1997-2004

(Index: 1990=100)

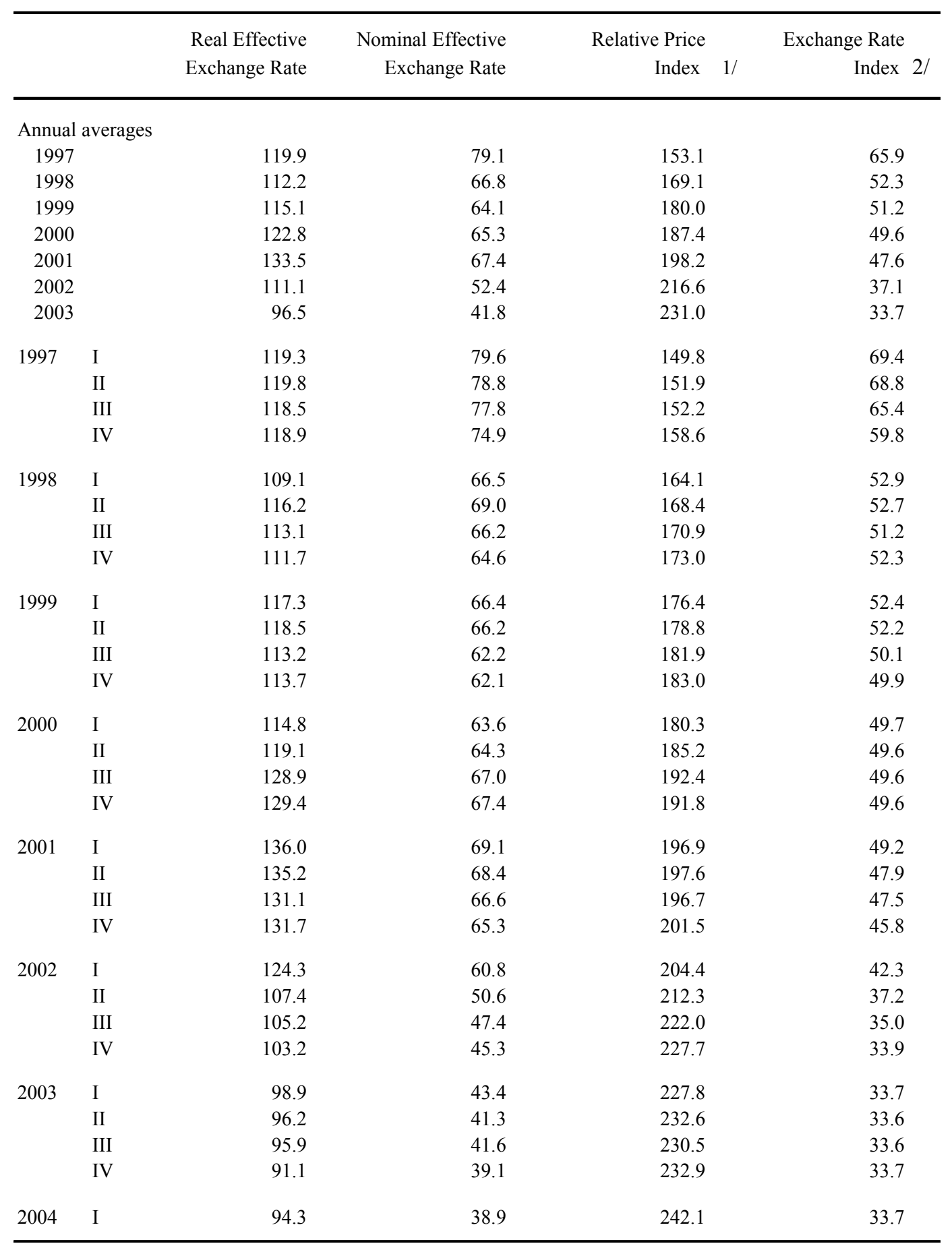

Sources: IMF, Information Notice System; and Central Bank of Solomon Islands.

1/ Consumer price index in the Solomon Islands relative to a weighted average of consumer price indices in major trading partners.

2/ U.S. dollar/Solomon Islands dollar exchange rate index. 